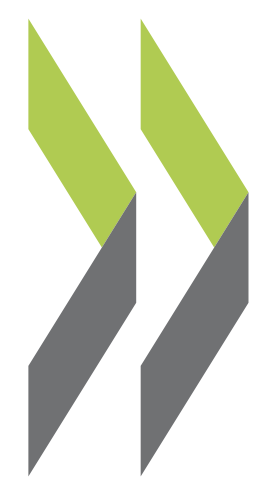

OECD Economics Department Working Papers No. 1048

A Projection Method

for Public Health and LongTerm Care Expenditures
Christine de la Maisonneuve,

Joaquim Oliveira Martins 
Organisation de Coopération et de Développement Économiques

Organisation for Economic Co-operation and Development

14-Jun-2013

ECONOMICS DEPARTMENT

English - Or. English

\section{A PROJECTION METHOD FOR PUBLIC HEALTH AND LONG-TERM CARE EXPENDITURES}

ECONOMICS DEPARTMENT WORKING PAPERS No. 1048

By Christine de la Maisonneuve and Joaquim Oliveira Martins

All Economics Department Working Papers are available through OECD's Internet website at www.oecd.org/eco/Workingpapers

JT03341900

Complete document available on OLIS in its original format

This document and any map included herein are without prejudice to the status of or sovereignty over any territory, to the delimitation of international frontiers and boundaries and to the name of any territory, city or area. 


\section{ABSTRACT/RÉSUMÉ}

\section{A projection method for public health and long-term care expenditures}

This paper proposes a new set of public health and long-term care expenditure projections until 2060, seven years after a first set of projections was published by the OECD. It disentangles health from longterm care expenditure, as well as the demographic from the non-demographic drivers, and refines the previous methodology, in particular by extending the country coverage. Regarding health care, nondemographic drivers are identified, with an attempt to better understand the residual expenditure growth by determining which share can be explained by the evolution of health prices and technology effects. Concerning LTC, an estimation of the determinants of the number of dependants (people needing help in their daily life activities) is provided. A cost-containment and a cost-pressure scenario are provided, together with sensitivity analysis. On average across OECD countries, total health and long-term care expenditure is projected to increase by 3.3 and 7.7 percentage points of GDP between 2010 and 2060 in the cost-containment and the cost-pressure scenarios respectively. For the BRIICS over the same period, it is projected to increase by 2.8 and 7.3 percentage points of GDP in the cost-containment and the costpressure scenarios respectively.

JEL classification codes: H51; I12; J11; J14.

Keywords: Public health expenditures; long-term care expenditures; ageing populations; longevity; demographic and non-demographic effects; projection methods.

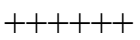

\section{Une méthode de prévisions des dépenses publiques de santé et de soins de longue durée}

Ce papier présente une nouvelle série de projections des dépenses publiques de santé et de soins de longue durée jusqu'en 2060, sept ans après la publication d'une première série de projections par l'OCDE. Le papier étudie la santé et les soins de longue durée séparément ainsi que les déterminants démographiques et non-démographiques et il affine la méthodologie adoptée précédemment, en particulier, en augmentant le nombre de pays couverts. En ce qui concerne la santé, les déterminants non-démographiques sont identifiés, l'analyse effectuée dans ce papier tentant de mieux comprendre la croissance résiduelle des dépenses en déterminant quelle part peut être attribuée à l'évolution des prix de la santé et de la technologie. En ce qui concerne les soins de longue durée, une estimation des déterminants du nombre de dépendants (personnes nécessitant de l'aide dans les activités de la vie quotidienne) est utilisée. Un scénario de maîtrise des coûts et un scénario de tension sur les coûts sont élaborés ainsi qu'une analyse de sensibilité. En moyenne sur l'ensemble des pays de l'OCDE, entre 2010 et 2060, le total des dépenses de santé et de soins de longue durée devrait augmenter de 3.3 points de pourcentage de PIB dans le scénario de maîtrise des coûts et de 7.7 points de pourcentage de PIB dans le scénario de tension sur les coûts. Pour les BRIICS sur la même période, il devrait augmenter de 2.8 points de pourcentage du PIB dans le scenario de maitrise des coûts et de 7.3 points de pourcentage dans le scenario de tension sur les coûts.

Classification JEL : $\mathrm{H} 51 ; \mathrm{I} 12 ; \mathrm{J} 11 ; \mathrm{J} 14$.

Mots-clés : Dépenses publiques de santé ; Dépenses publiques de soins à long terme ; vieillissement de la population ; longévité ; effets démographiques et non démographiques ; méthodes de projection.

You can copy, download or print OECD content for your own use, and you can include excerpts from OECD publications, databases and multimedia products in your own documents, presentations, blogs, websites and teaching materials, provided that suitable acknowledgment of OECD as source and copyright owner is given. All requests for commercial use and translation rights should be submitted to rights@oecd.org. 


\section{TABLE OF CONTENTS}

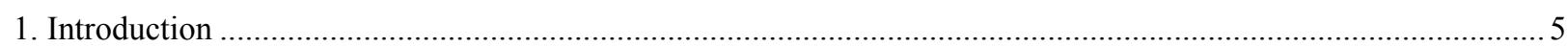

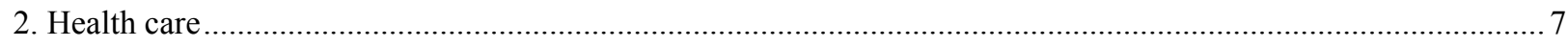

2.1 The determinants of public health care expenditure ……….................................................................

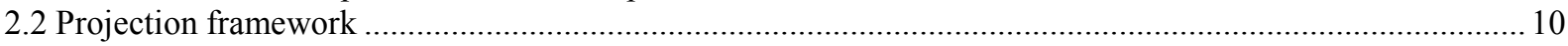

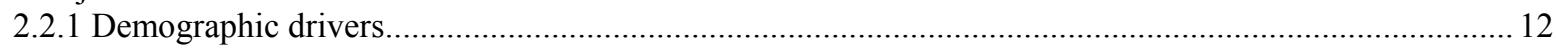

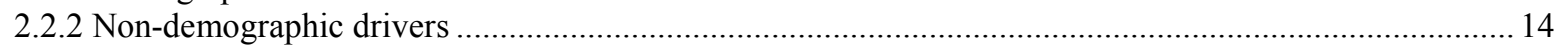

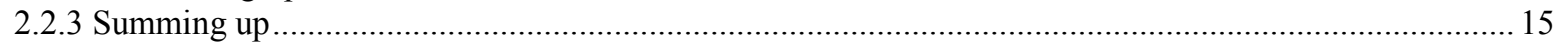

2.3 Projection results: public health expenditures, 2010-2060 .................................................................... 17

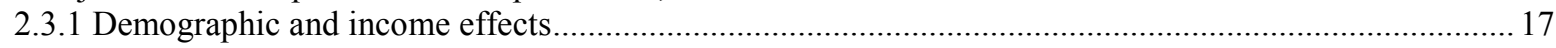

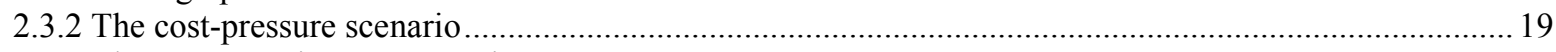

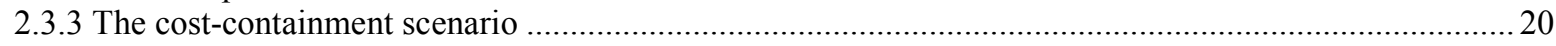

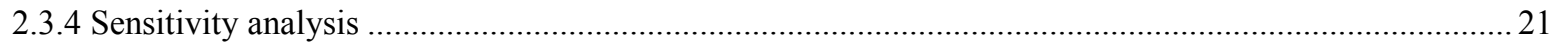

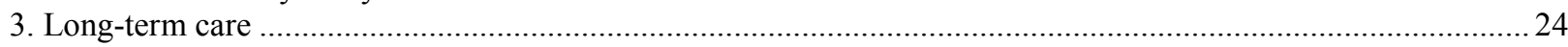

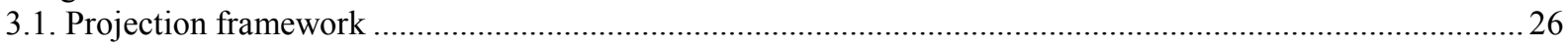

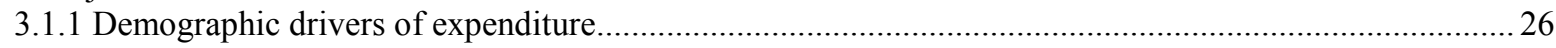

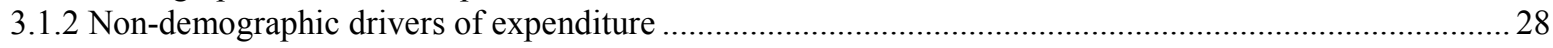

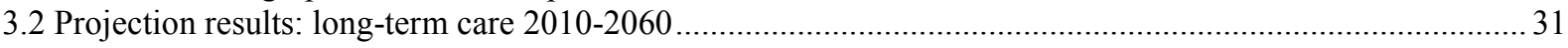

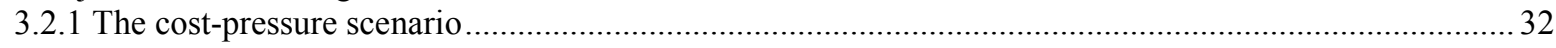

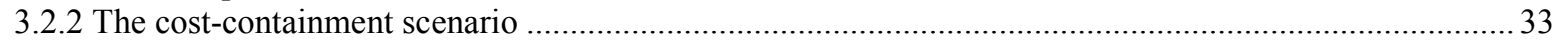

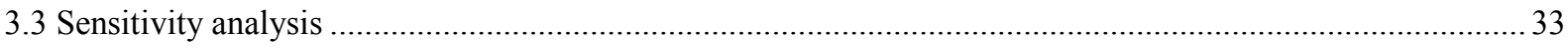

4. Prospects for total public spending on health and comparison with other projections .........................................35

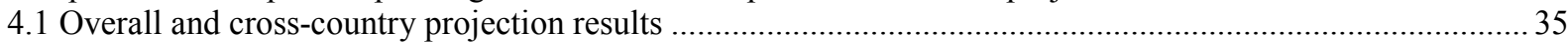

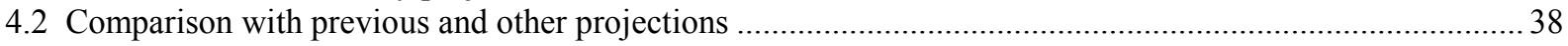

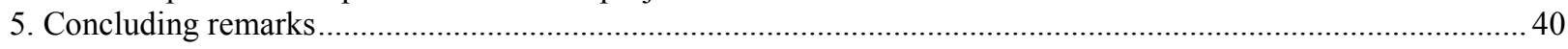

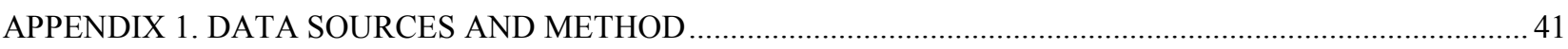

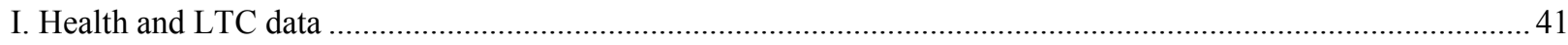

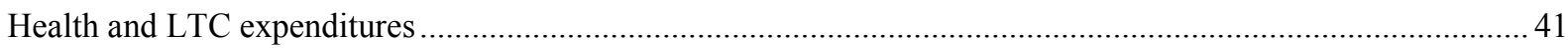

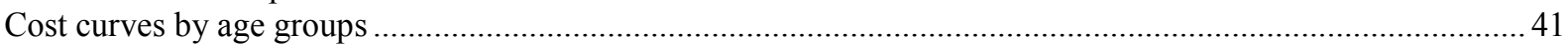

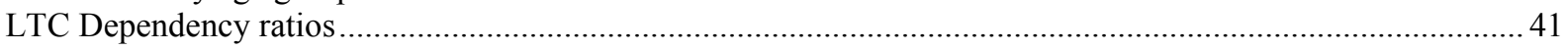

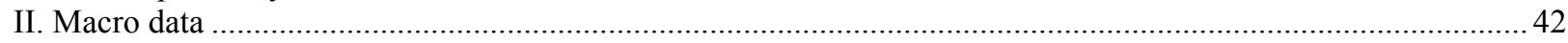

GDP

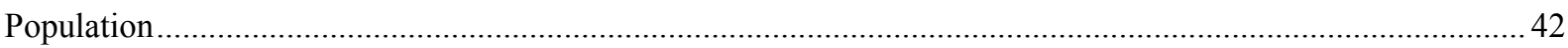

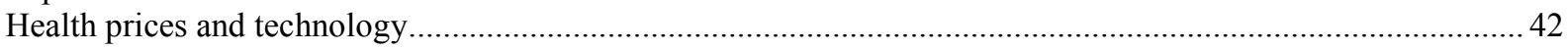

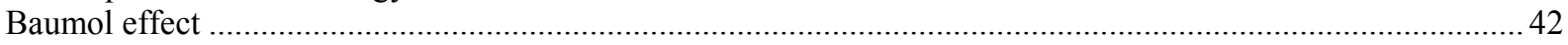

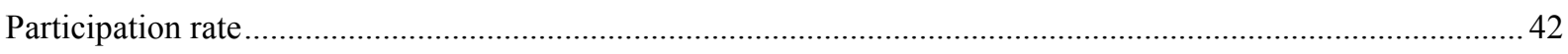

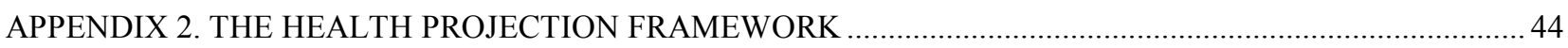

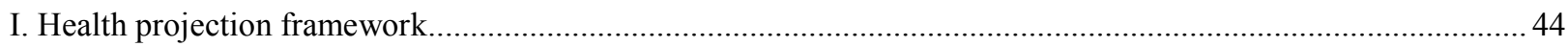

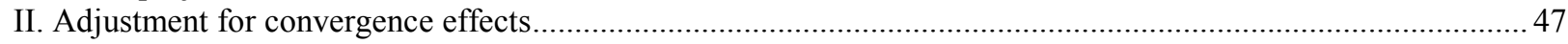

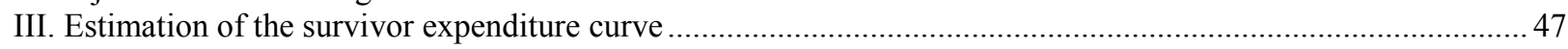

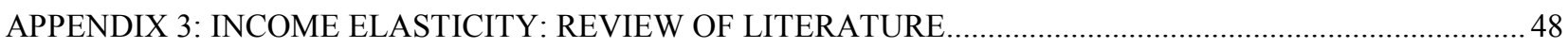

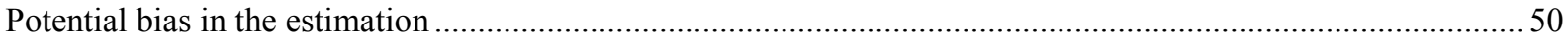

APPENDIX 4. ESTIMATIONS TO CALIBRATE THE LTC FRAMEWORK …….................................................... 53

APPENDIX 5. DETAILED SCENARIO RESULTS FOR HEALTH AND LONG-TERM CARE..............................54

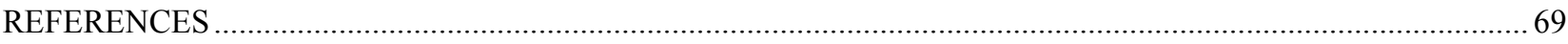

Tables

2.1. Decomposing growth in public health spending (1995-2009) ................................................................

2.2. Assumptions underlying the alternative projection scenarios: public health care ........................................... 17 


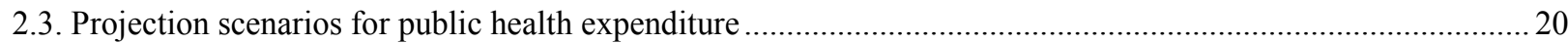

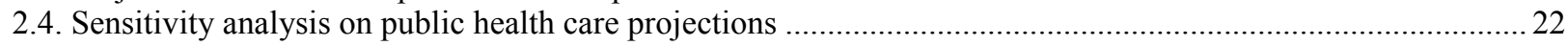

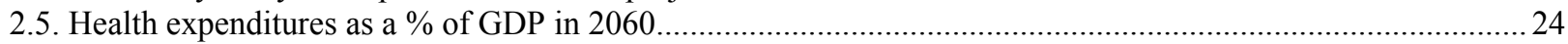

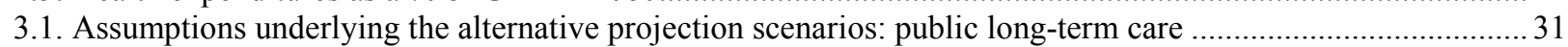

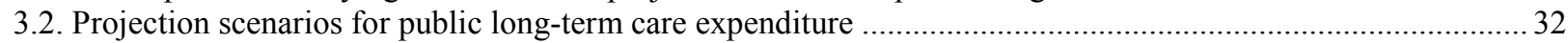

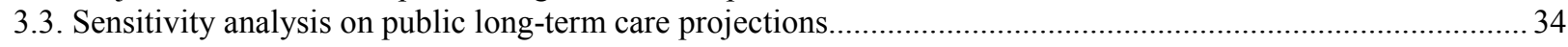

4.1. Projection scenarios for public health and long-term care spending ….............................................. 37

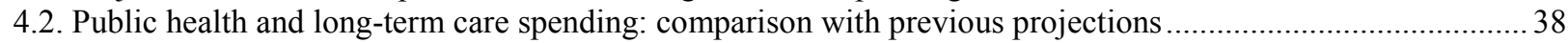

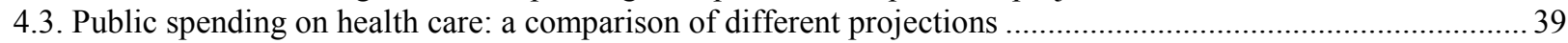

A2.1. Real public health care expenditure per capita: econometric estimates ..............................................46

A3.1. Survey of income elasticity estimates of health-care expenditures ....................................................49

A3.2. Selected recent income elasticity estimates of health care expenditures ................................................. 51

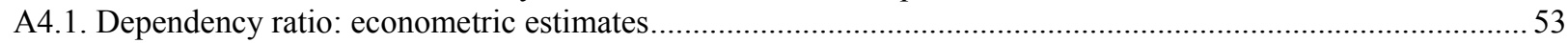

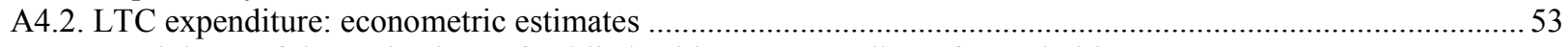

A5.1. Breakdown of the projections of public health care expenditure for each driver.........................................5 54

A5.2. Breakdown of the projections of public health care expenditure for each driver..........................................55

A5.3. Breakdown of the projections of public health care expenditure for each driver.........................................56

A5.4. Breakdown of the projections of public health care expenditure for each driver......................................57

A5.5. Breakdown of the projections of public health care expenditure for each driver......................................58

A5.6. Breakdown of the projections of public health care expenditure for each driver.........................................59

A5.7. Breakdown of the projections of public health care expenditure for each driver.........................................60

A5.8. Breakdown of the projections of public health care expenditure for each driver......................................61

A5.9. Breakdown of the projections of public health care expenditure for each driver.....................................62

A5.10. Breakdown of the projections of public health care expenditure for each driver......................................63

A5.11. Breakdown of the projections of public health care expenditure for each driver.....................................64

A5.12. Breakdown of the projections of public health care expenditure for each driver....................................65

A5.13. Breakdown of the projections of public health care expenditure for each driver........................................66

A5.14. Breakdown of the projections of public health care expenditure for each driver......................................67

A5.15. Breakdown of the projections of public health care expenditure for each driver...................................... 68

\section{Figures}

1.1. Evolution of public health and long-term care expenditures .............................................................. 6

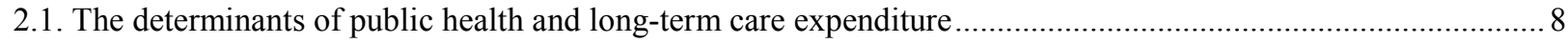

2.2. Evolution of public health and long-term care expenditure .................................................................... 10

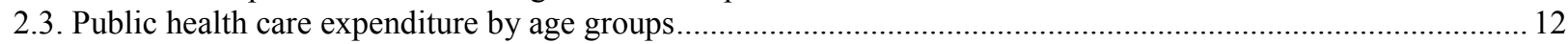

2.4. Shifts in expenditure profiles, ageing and non-ageing effects .............................................................. 16

2.5. Shares of health care expenditure by age in total health care expenditure ............................................... 18

3.1. Public long-term care expenditure per beneficiary as a \% of GDP per capita .........................................25

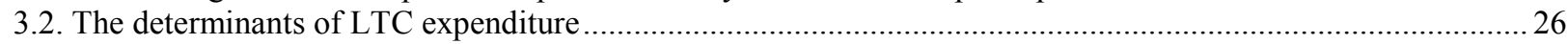

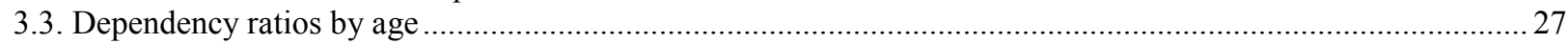

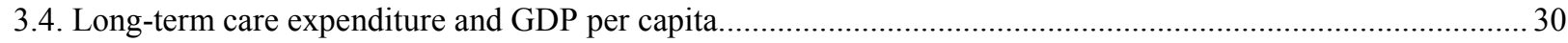

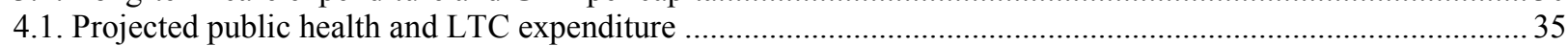

4.2. Percentage point increase in total public health and long-term care spending ratio to GDP, $2010-2060 \ldots \ldots \ldots . .36$

\section{Boxes}

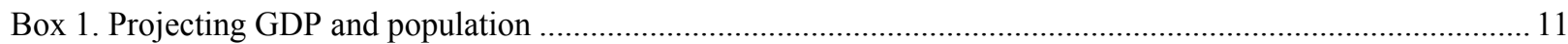

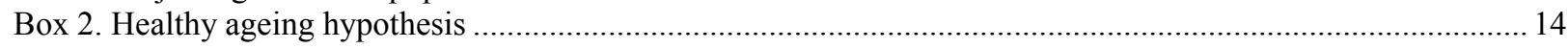

Box 3. Explaining health care expenditure growth that is unrelated to demographics and income........................15

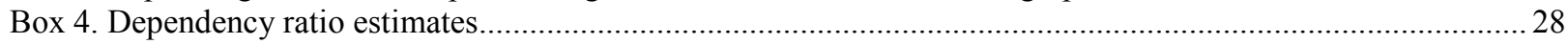

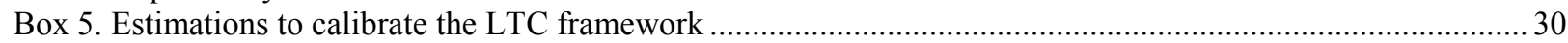

The statistical data for Israel are supplied by and under the responsibility of the relevant Israeli authorities. The use of such data by the OECD is without prejudice to the status of the Golan Heights, East Jerusalem and Israeli settlements in the West Bank under the terms of international law. 
ECO/WKP(2013)40

\title{
A PROJECTION METHOD FOR PUBLIC HEALTH AND LONG-TERM CARE EXPENDITURES
}

\author{
By Christine de la Maisonneuve and Joaquim Oliveira Martins ${ }^{1}$
}

\section{Introduction}

1. Spending on health and long-term care (henceforth LTC) is a first-order policy issue for most governments in OECD countries. These expenditures are putting pressure on public budgets, adding to that arising from other social spending programmes and, once interest rates normalise, servicing of higher debt levels than in the past. The ratio of public health and LTC expenditure to GDP ${ }^{2}$ has been rising steadily for several decades. Since 1970, on average across OECD countries, the expenditure to GDP ratio has increased by 3.5 percentage points to reach around 7 percentage points in 2010. Looking towards the future, the OECD (2006) public health and LTC spending projections highlighted the growing pressures over the next 50 years. In an upside "cost-pressure" scenario, average health and LTC expenditure was projected to almost double again, to reach approximately $13 \%$ of GDP by 2050 . But, even in the so-called "cost-containment" scenario, spending was still projected to rise to approximately $10 \%$ of GDP on average across OECD countries over the next 50 years. Comparing the 2006 OECD projections with actual data up to 2010 (Figure 1.1, panel A), the observed increase in the ratio of public health and LTC spending to GDP was above even the pessimistic "cost-pressure scenario". On average for OECD countries, these expenditures have represented an increasing share of total public expenditures (Figure 1.1, panel B).

2. The projections in this paper update and refine the OECD (2006) analysis by extending the country coverage and improving the method of estimating future developments in health and LTC expenditure. In addition to the 34 OECD countries, health and LTC expenditure is also projected for Brazil, China, India, Indonesia, Russia and South Africa (henceforth BRIICS). Concerning the methodology, as in 2006, the new projections separate health and LTC and, within each type of expenditure, demographic from non-demographic drivers. For health care, the main difference concerns the non-demographic drivers, with an attempt to better understand the residual expenditure growth by

1 The authors are respectively members of the Economics Department and the Directorate for Public Governance and Territorial Development. Correspondence: christine.maisonneuve@oecd.org and joaquim.oliveira@oecd.org. They would like to thank Jørgen Elmeskov, Fabrice Murtin, Giuseppe Nicoletti and Jean-Luc Schneider for their valuable comments as well as their colleagues from the Health Division of the Directorate for Employment, Labour and Social Affairs for the provision of data and their helpful suggestions. The authors would also like to thank the participants at the OECD "Expert Workshop on Improving Health Expenditure Forecasting Methods", 30 November, 2012, Paris, in particular Thomas Getzen and Michael Wolfson. Special thanks go to Robert Price for helpful suggestions and to Irene Sinha and Penny Elghadab for excellent technical and editing assistance. The views expressed in this paper are those of the authors and do not necessarily reflect those of the OECD and its member countries

2 To focus on the structural factors and eliminate cyclical effects, the ratio is computed using trend instead of actual GDP (from the OECD Economic Outlook, No. 91). 
determining which share can be explained by the evolution of health prices and technology effects. Regarding LTC, a more precise estimation of the determinants of the number of dependants (people needing help in their daily life activities) is provided. In particular, the current set of projections treats health expenditure itself as a determinant of the dependency ratios (number of dependent people in total population) by age groups. Finally, the new projections extend to 2060 .

3. The projections are provided for public expenditure only. Nonetheless, the cross-country differences in treatment of tax expenditures, ${ }^{3}$ which can be large in some cases, may introduce serious bias in the split between public and private expenditures. Indeed, countries interpret differently the OECD manual on the System of Health accounts on how to deal with tax expenditures. Australia and Germany, for instance, deduct tax expenditures from private insurance expenditures and report it as public expenditure. But, in the United States, tax expenditures are not considered as public expenditure (OECD, 2010).

Figure 1.1 Evolution of public health and long-term care expenditures ${ }^{1}$

A. Comparison of actual developments and OECD (2006) projections (in \% of trend $\mathrm{GDP}^{2}$ )

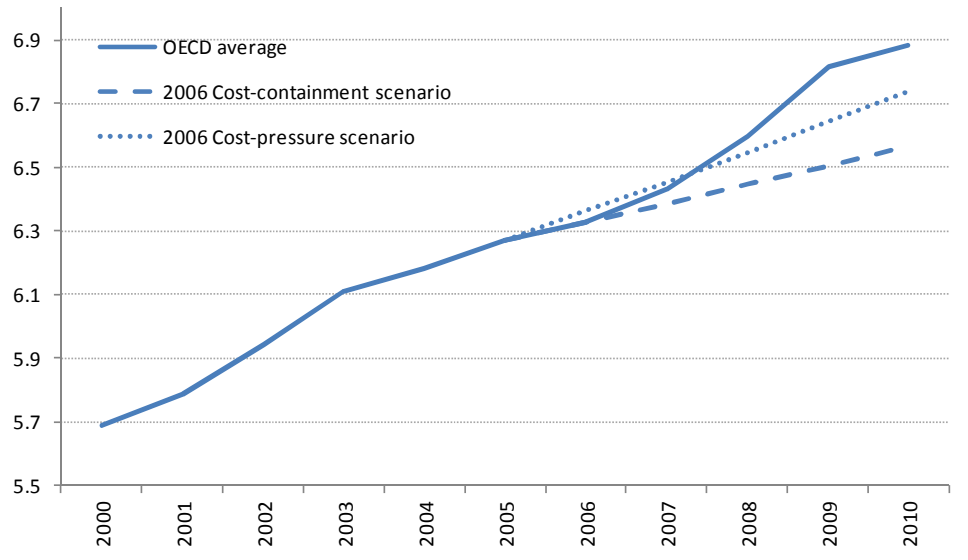

3 Tax expenditure can be of different kinds, e.g. exclusion from workers' taxable income of employers' health insurance contributions in the United States, tax credits for medical expenses in Canada or income tax deductions for health care services in Portugal. 
B. Share of health and LTC spending in total public spending (in \% of total public expenditure)

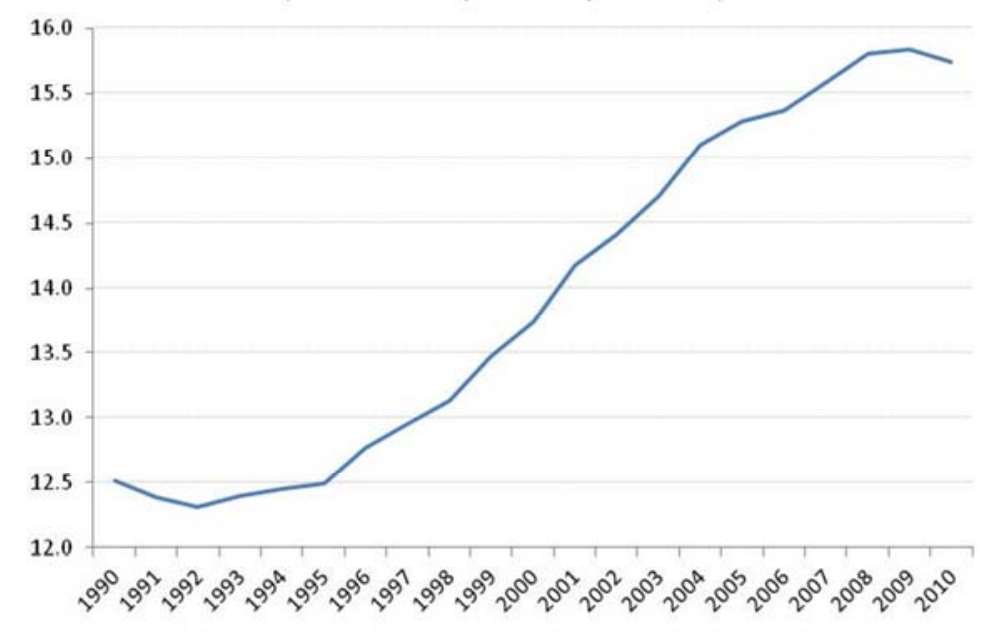

1. Unweighted average of available OECD countries.

2. The trend GDP was derived from the OECD Economic Outlook database.

Source: OECD Health Database (2011), OECD (2006), OECD Economic Outlook database no. 91

4. The paper is set out as follows. In Section 2, the main demographic and non-demographic drivers of public health expenditure are analysed and projected over the next half century. Cost-containment (with implicit policy actions) and cost-pressure (without policy actions) scenarios are presented, followed by a discussion of the sensitivity of the results to key assumptions. In Section 3, the same sequence applies to public LTC expenditures. In Section 4, different health and LTC expenditure scenarios are combined in order to provide a range of estimates for total expenditure. They are compared with previous OECD estimates as well as estimates from other institutions and some policy implications are drawn. Section 5 concludes.

\section{Health care}

\subsection{The determinants of public health care expenditure}

5. The drivers of public health care expenditure are demographic and non-demographic (Figure 2.1). Demographic drivers relate broadly to the age structure of the population and the evolution of its health status, while a non-demographic driver is income. The responsiveness of health expenditures to income remains an unsettled issue (see Appendix 3), but independent of the precise income elasticity the combination of demographic and income effects fails to explain a large part of the total growth in public health-care expenditure in the past. Thus, a residual unexplained growth remains. Relative prices, technological progress and the underlying health policies and institutions are the most likely candidates for explaining this residual (see Box 3). 
Figure 2.1 The determinants of public health expenditure

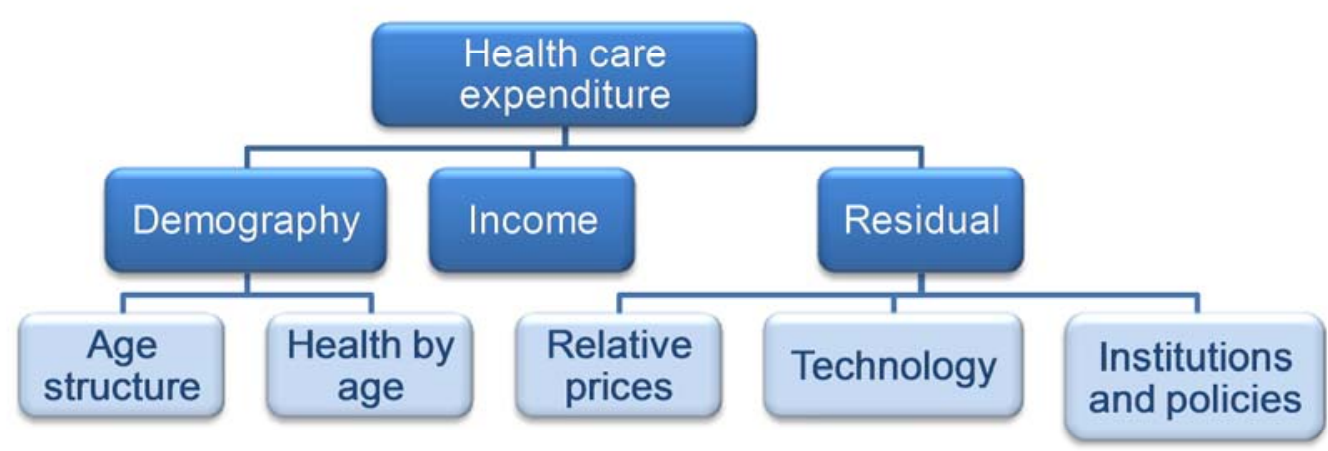

6. To quantify the relative contribution of each driver over the past 15 years, a simple accounting analysis was carried out (See Appendix 1 for data sources and methodology). The analysis accounts for changes in the population structure during the period 1995-2009, and assumes an income elasticity of health spending of either 0.8 or 1 (see below for a discussion of this hypothesis). Based on these assumptions an expenditure residual was derived. As can be seen from Table 2.1, demographic drivers explain relatively little of past developments in health spending. Between 1995 and 2009, public health spending grew on average and in real terms (adjusted for overall inflation) by $4.3 \%$ per year in OECD countries, of which only 0.5 percentage points can be attributed to 'pure demographic' developments. Assuming an income elasticity equal to 0.8 , income effects add 1.7 percentage points of growth on top of the 0.5 percentage points attributable to demographics. Therefore, a residual growth can be estimated at around 2 percentage points per year on average across OECD countries, with the BRIICS experiencing even more important residual growth effects. ${ }^{4}$ With an income elasticity of one, the residual on average for the OECD would still be around $1.5 \%$ per year. Only with a somewhat unrealistic income elasticity of 1.8 , demographic and income effects could explain most of the observed expenditure growth.

The demographic component of this "growth accounting" is obtained by applying an average cross-country curve of health expenditures by age observed in 2009 to the changes in the age structure of the population experienced over the 1995-2009 period. Using the 2009 curve (which is the only available data point) may lead to an underestimation of the past demographic effect for two reasons. First, this cost curve fails to reflect lower life expectancies in the past. Given that health costs tend to spike in the period just preceding death (the so-called "death-related costs"), the proximity to death is implicitly assumed to have played a lesser role for health spending of past old age cohorts. Second, increases in life expectancy over the period 1995-2009 are likely to have been matched by corresponding improvements in health status at older age (the so-called "healthy ageing" hypothesis), which may have decreased older age health costs over time. Attributing the end-year (2009) health status, and corresponding health spending, to cohorts living in the previous four decades also tends to underestimate the demographic effect. In turn, underestimation of this effect leads, ceteris paribus, to an overestimation of the expenditure residual. Nonetheless, this bias is likely to be small as suggested by the subsequent projections. 
Table 2.1 Decomposing growth in public health spending (1995-2009) ${ }^{1}$

\begin{tabular}{|c|c|c|c|c|c|}
\hline & $\begin{array}{c}\text { Real health } \\
\text { spending (per } \\
\text { capita in } 2005 \\
\text { PPPUS\$) }\end{array}$ & Age effect & $\begin{array}{c}\text { Income effect } \\
\text { (Income elasticity }=0.8 \text { ) }\end{array}$ & Residual $^{2}$ & $\begin{array}{c}\text { Memo item: } \\
\text { Residual with } \\
\text { unitary income } \\
\text { elasticity }\end{array}$ \\
\hline & $\begin{array}{c}\text { (Average annual } \\
\% \text { change) }\end{array}$ & \multicolumn{4}{|c|}{ (Average annual \% contribution to change in spending) } \\
\hline Australia & 4.1 & 0.4 & 1.7 & 1.8 & 1.4 \\
\hline Austria & 3.3 & 0.4 & 1.3 & 1.5 & 1.2 \\
\hline Belgium & 4.2 & 0.4 & 1.2 & 2.7 & 2.4 \\
\hline Canada & 2.6 & 0.6 & 1.3 & 0.8 & 0.5 \\
\hline Chile & 7.7 & 0.6 & 2.2 & 4.8 & 4.3 \\
\hline Czech Republic & 4.2 & 0.6 & 2.3 & 1.4 & 0.8 \\
\hline Denmark & 3.7 & 0.2 & 0.8 & 2.7 & 2.5 \\
\hline Estonia & 6.1 & 0.6 & 3.9 & 1.8 & 1.0 \\
\hline Finland & 4.1 & 0.6 & 2.0 & 1.5 & 1.1 \\
\hline France & 1.6 & 0.5 & 0.9 & 0.3 & 0.0 \\
\hline Germany & 1.7 & 0.6 & 0.8 & 0.2 & 0.0 \\
\hline Greece & 5.9 & 0.6 & 2.7 & 2.5 & 1.8 \\
\hline Hungary & 2.0 & 0.5 & 2.1 & -0.6 & -1.1 \\
\hline Iceland & 3.1 & 0.4 & 2.0 & 0.9 & 0.4 \\
\hline Ireland & 6.5 & 0.3 & 2.9 & 3.3 & 2.6 \\
\hline Israel & 1.6 & 0.4 & 2.4 & -1.2 & -1.7 \\
\hline Italy & 3.1 & 0.6 & 0.4 & 2.1 & 2.0 \\
\hline Japan & 2.7 & 1.2 & 0.8 & 0.7 & 0.5 \\
\hline Korea & 11.0 & 1.1 & 3.1 & 6.5 & 5.7 \\
\hline Luxembourg & 1.9 & 0.1 & 2.3 & -0.5 & -1.1 \\
\hline Mexico & 2.5 & 0.5 & 1.1 & 1.0 & 0.7 \\
\hline Netherlands & 5.2 & 0.5 & 1.4 & 3.3 & 2.9 \\
\hline New Zealand & 6.3 & 0.4 & 0.3 & 5.5 & 5.5 \\
\hline Norway & 3.5 & 0.1 & 1.3 & 2.1 & 1.7 \\
\hline Poland & 6.9 & 0.7 & 3.6 & 2.6 & 1.7 \\
\hline Portugal & 4.6 & 0.6 & 1.5 & 2.4 & 2.0 \\
\hline Slovak Republic & 6.3 & 0.6 & 3.6 & 2.1 & 1.3 \\
\hline Slovenia & 3.0 & 0.8 & 2.1 & 0.2 & -0.3 \\
\hline Spain & 3.4 & 0.5 & 1.5 & 1.4 & 1.0 \\
\hline Sweden & 3.2 & 0.2 & 1.6 & 1.4 & 1.0 \\
\hline Switzerland & 2.9 & 0.4 & 0.9 & 1.6 & 1.4 \\
\hline Turkey & 7.7 & 0.5 & 2.6 & 4.5 & 3.9 \\
\hline United Kingdom & 4.6 & 0.2 & 1.5 & 2.8 & 2.5 \\
\hline United States & 3.6 & 0.3 & 1.1 & 2.3 & 2.0 \\
\hline Brazil & 4.8 & 0.6 & 1.2 & 2.9 & 2.6 \\
\hline China & 11.2 & 0.6 & 7.3 & 3.0 & 1.3 \\
\hline India & 6.6 & 0.3 & 4.2 & 2.0 & 1.0 \\
\hline Indonesia & 8.0 & 0.5 & 1.9 & 5.5 & 5.0 \\
\hline Russia & 3.7 & 0.4 & 3.3 & 0.1 & -0.6 \\
\hline South Africa & 3.1 & 0.4 & 1.6 & 1.2 & 0.8 \\
\hline OECD total average & 4.3 & 0.5 & 1.8 & 2.0 & 1.5 \\
\hline BRIICS average & 6.2 & 0.5 & 3.2 & 2.5 & 1.7 \\
\hline Total average & 4.6 & 0.5 & 2.0 & 2.0 & 1.5 \\
\hline
\end{tabular}

1. Or latest available year. Figures may not add up due to rounding.

2. The residual expenditure growth is computed by subtracting the age effect as described in footnote 4 as well as the increase in income (using an elasticity of 0.8) from the increase in real health spending. Accordingly, denoting he, the real health spending, Age, the age effect, and $Y / N$, the real income per capita, the residual expenditure growth (Res) is expressed as follows:

$\dot{R e s}=\dot{h e}-\dot{A g} e-0.8 * Y \dot{~} N$ 
7. The calculated expenditure residual growth displays large differences across countries (Figure 2.2). It ranges from above 5\% per year for countries such as Korea and New Zealand, to values well below $0.5 \%$ for France, Germany, Slovenia and Russia, and is even negative for Israel. Extrapolating these country-specific idiosyncrasies over the next 50 years may generate unreliable results as most of them would lead to unsustainable expenditure ratios. For this reason, in this study, it was preferred to use a common average residual growth (see below).

Figure 2.2. Health care residual expenditure growth by country (1995-2009)

(Annual average growth rates in \%)

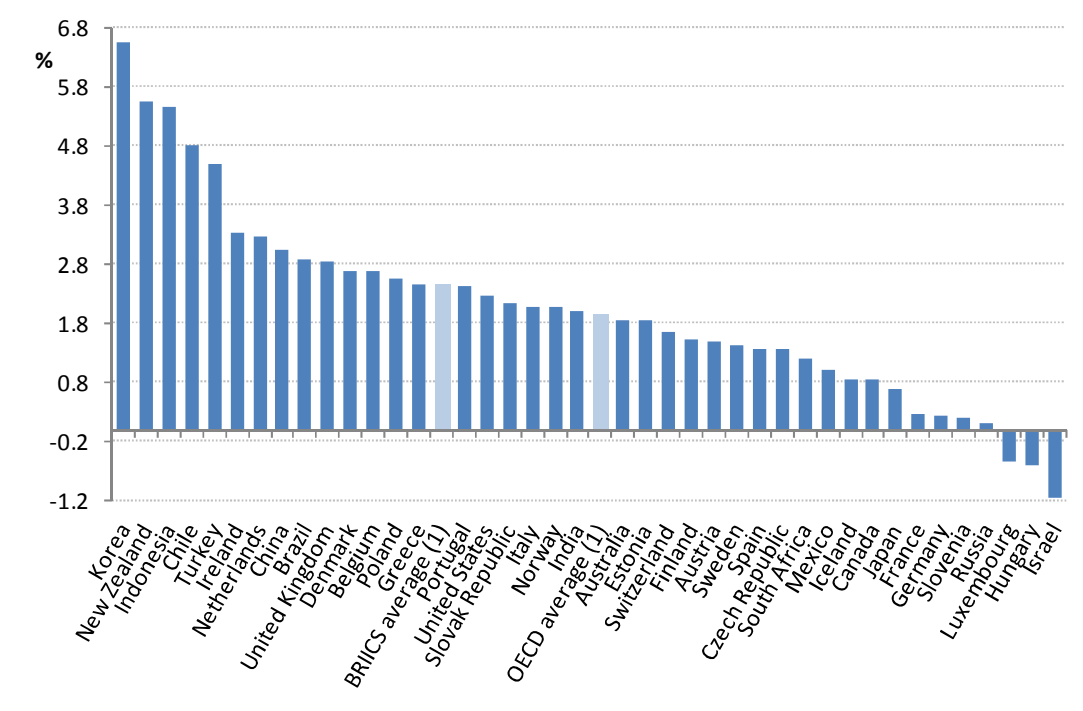

1. Unweighted average.

Source: OECD Health Database (2011) and authors' calculations

\subsection{Projection framework}

8. The framework used to project public health expenditure combines both the demographic and non-demographic drivers described above. The evolution of each driver is first projected separately, and subsequently combined to compute the future growth of total health expenditure (for details see Appendix 2). The share of public health care spending in GDP (denoted by $H E / P_{Y} Y$ with $H E$, health expenditure, $Y$ real income and $P y$, the GDP deflator) is related to a demographic effect (Demo), real income per capita $(Y / N$, where $N$ is total population), and a residual (Res). The precise data sources and definitions of the variables used in the public health care projections are described below and in Appendix 1, but the simplified logarithmic growth equation used to project the evolution of spending ratios can be denoted as follows:

$$
\Delta \log \left(\frac{H E}{P_{Y} \cdot Y}\right)=\Delta \log (\text { Demo })+(\varepsilon-1) \cdot \Delta \log \left(\frac{Y}{N}\right)+\Delta \log (\text { Res })
$$

where the GDP deflator is assumed to remain constant during the projection period. Demo is a combination of three demographic-related factors described in Section 2.2.1 (death-related costs, pure age effects and a healthy-ageing effect); $\varepsilon$ is the income elasticity of health expenditures (it can take the value of 0.8 or 1 depending on the scenario, see Appendix 2); and Res is the residual growth factor.

9. The growth rates in spending ratios are first projected for each country and they are then adjusted to allow for a certain convergence across countries towards a common target level (Appendix 2). Ceteris 
paribus, countries having a below average initial level of public health expenditure to GDP ratios are projected to experience higher growth rates than those close to the average. This makes the projections more comparable across countries, as the effects of the different mechanisms at work during the projection period are isolated from the impact of the initial conditions. In order to smooth out the impact of the recent crisis on expenditure, the base year spending ratios are computed as the average shares of public health care spending in GDP over 2006-2010.

10. This framework is used to project public health care expenditures over the period 2010-60. The spending projections in turn rely on the GDP projections published in the OECD Economic Outlook, No.91, as well as population projections drawn from different sources. Box 1 provides detailed information about the underlying GDP and population projections.

\section{Box 1. Projecting GDP and population}

Public health spending projections depend on expected developments in GDP and demographics. The population projections are sourced from Eurostat for European OECD countries, while for non-European countries projections are from the United Nations Population Database. These projections assume that in the long term total fertility will approach the replacement-level of 2.1 , without necessarily reaching it. Gains in life expectancy are projected to be smaller than those observed recently in both data sets, while differences in life expectancy across gender are assumed to narrow. Finally, the future path of international migration is such that projected levels of net migration are generally kept constant at their current levels over the next decades in both datasets, although after 2050 it is assumed that net migration will gradually decline.

GDP projections, published in the OECD Economic Outlook, No. 91, are based on a standard aggregate CobbDouglas production function with constant returns to scale featuring physical capital, human capital, labour and Harrodneutral technical progress, which can be expressed as:

$$
Y_{i t}=\left(K_{i t} / Y_{i t}\right)^{\alpha /(1-\alpha)} A_{i t} h_{i t} L_{i t}
$$

where $\mathrm{Y}, \mathrm{K}, \mathrm{A}, \mathrm{h}$ and $\mathrm{L}$ denote output, physical capital, technical progress, human capital per worker, employment, respectively, and subscripts $t$ and $i$ denote year and country, respectively. The share of capital $\alpha$ is set equal to $1 / 3$.

Employment is further decomposed into trend population (POP), the trend labour force participation rate (LFPR) and the trend unemployment rate $(\mathrm{u})$ according to:

$$
L_{i t}=P O P_{i t} * \operatorname{LFPR}_{i t} *\left(1-u_{i t}\right)
$$

Starting from a base year, these components of the production function are projected up to 2060 in order to compute potential GDP measured in terms of constant 2005 USD purchasing power parities (PPPs).

The vision of growth underlying the GDP projections is one in which each country would be expected to converge to its own steady-state trajectory of GDP per capita determined by the interface between global technological development and country-specific structural conditions and policies (so-called conditional convergence). In the longrun, all countries are expected to grow at the rate determined by the worldwide rate of technical progress, but crosscountry GDP per capita gaps would remain, mainly reflecting differences in technology levels, capital intensity and human capital. For more details see Duval and de la Maisonneuve (2010), and Johansson et al. (2012). A similar approach has been followed by Fouré et al. (2010). 


\subsubsection{Demographic drivers}

11. The base information used to construct the health expenditure projection framework is the average health expenditure profile by age group (Figure 2.3). ${ }^{5}$ Average health expenditures are relatively high for young children; they decrease and remain stable for most of the prime-age period, and then start to increase rapidly in older age, the health care cost of people aged 90 and over being six times that of young people. Until the age of 65 , health expenditure profiles are rather similar across countries, but from 65 onwards they display a large heterogeneity. The standard deviation by age group increases from $1.8 \%$ for the 65-69 age group to more than 5\% for people aged 90 and over.

12. From Figure 2.3 it could be expected a priori that an ageing population would be associated with increasing aggregate per capita public health care expenditures: the fact that the share of older people in the population is growing faster than that of any other age group, both as a result of longer lives and a lower birth rate, should generate an automatic increase in the average. However, this intuition finds little support in the data and assessing the effect of population ageing on health and health care has proved to be far from straightforward (Breyer et al., 2011). This effect is also difficult to extrapolate: while the effect of ageing is likely to increase public health expenditures per capita in the future, it has been weak in the past. ${ }^{6}$ Zweifel et al., (1999) even defined as a "red herring" the idea that ageing has a significant impact on health expenditure.

Figure 2.3. Public health care expenditure by age groups ${ }^{1}$

(\% of GDP per capita)

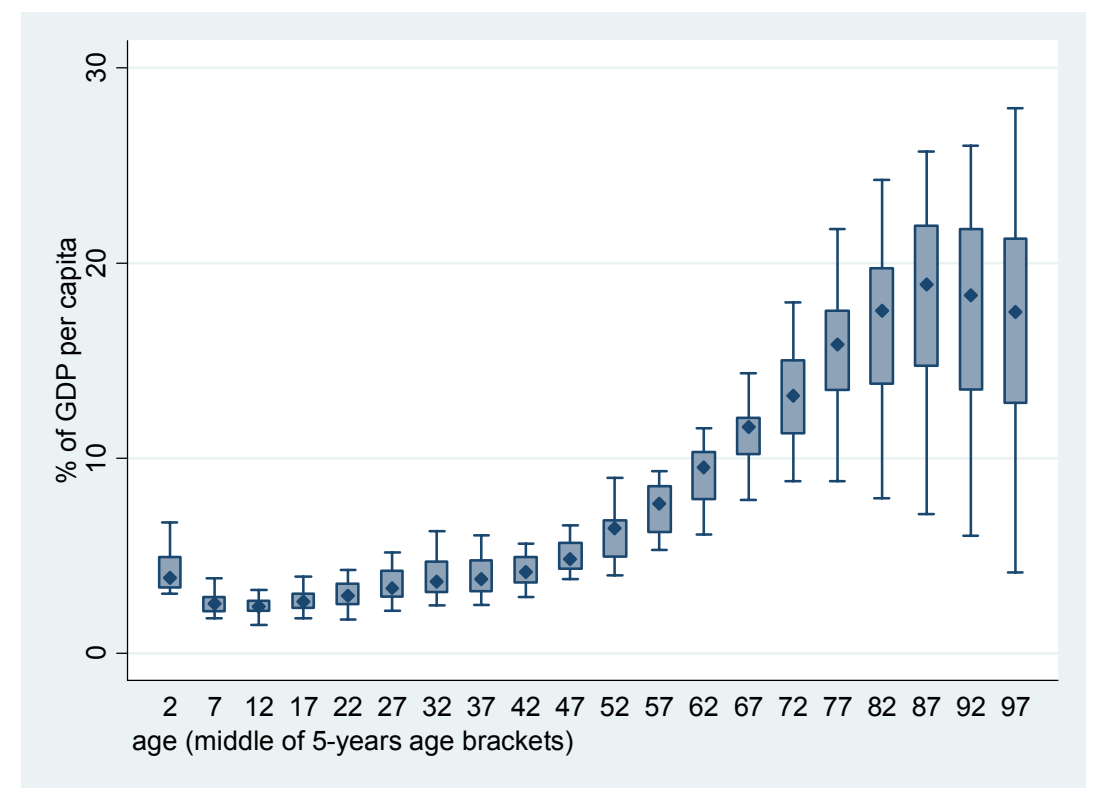

1. The graph shows the dispersion of health care expenditure across countries by age groups. The diamonds represent the median. The boxes are the $2^{\text {nd }}$ and $3^{\text {rd }}$ quartiles of the distribution of expenditure across countries. The whiskers are the $1^{\text {st }}$ and $4^{\text {th }}$ quartiles.

Source: European Commission, 2009 Ageing Report: Economic and budgetary projections for the EU-27 Member States (20082060).

5 These cost curves have been provided by the European Commission for European countries (Ageing Report 2009) and have been drawn from national statistics for the other countries.

6 See Culyer (1990); Gerdtham et al., (1992); Hitiris and Posnett (1992); Zweifel et al., (1999); Richardson and Roberston (1999); Moise and Jacobzone (2003); Jönsson and Eckerlund (2003). 
13. Consistent with a large number of previous studies (Felder et al., (2000), Seshamani and Gray (2004); Breyer and Felder (2006); and Werblow et al., (2007), etc.), this paper assumes that what matters for health spending is not ageing but rather the proximity to death, i.e the so-called "death-related costs" (DRC) hypothesis. This interpretation is consistent with the observed facts that health-care expenditure tends to increase in a disproportionate way when individuals are close to death, and mortality rates are obviously higher for older people. When the projected increase in life expectancy is accompanied by an equivalent gain in the number of years spent in good health, the health care spending is only driven by the proximity to death and not by an increase in the average age of the population. In other words, it is not ageing per se that pushes up average health expenditures, but rather the fact that mortality rates increase with age. The death-related costs hypothesis is, therefore, consistent with a so-called healthy-ageing regime, where longevity gains are all translated into years in good health (Box 2).

14. To account for the dominance of death-related costs and the healthy-ageing regime, the expenditure curve by age group needs to be split for each period into two segments of the population: survivors and non-survivors. The non-survivors' expenditure curve can be estimated by multiplying the estimated health costs in the proximity to death by age group by the number of deaths per age group. The "cost of death" was proxied here by the health expenditure per capita for the oldest age group (95+) multiplied by a factor that captures the tendency for the costs of death to be higher at younger ages. This factor is kept constant at 4 for people aged between 0 and 59 years and declines linearly (towards unity) afterwards.

15. As regards non-survivors, two different demographic effects are at play. On the one hand, the number of deaths is set to rise due to the transitory effect of the post-War baby-boom. On the other hand, if mortality falls over time due to an ongoing increase in longevity, fewer will be at the very end of life in each given year, thus mitigating health care costs. ${ }^{8}$ The impact of demographic developments on public health care expenditures will depend on the relative size of these effects.

16. In principle, the survivors' expenditure curve for each country could be derived from the difference between the total cost curve and that of the non-survivor (see OECD (2006) for more details). However, given the uncertainties surrounding these data, it seemed preferable to estimate an average expenditure curve for survivors, to be then used for all countries. In this way, the projections are less sensitive to initial conditions and to country-specific data idiosyncrasies. This expenditure curve for survivors was estimated econometrically as a non-linear function of age (see Appendix 2). Each countryspecific curve is then calibrated in order to fit the base year of the projections.

$7 \quad$ While the probability of dying increases with age, the costs of death tend to decline steadily after young and prime age (Aprile, 2004). Other estimates of DRC are coherent with this order of magnitude (e.g. Yang et al. (2003)).

$8 \quad$ See, for example Fuchs (1984); Zweifel et al. (1999); Jacobzone (2003); and Gray (2004). 


\section{Box 2. Healthy ageing hypothesis}

To take into account the "healthy ageing" hypothesis, the survivor expenditure curve is allowed to shift rightwards according to longevity gains, progressively postponing the age-related increases in expenditure. First, the curve by five-year age groups is interpolated in order to derive a yearly age profile. In this way, the expenditure curve can be shifted smoothly over time, in line with life expectancy gains.

Subsequently the shift of the curve can be simulated by subtracting the increase in life expectancy at birth according to national projections from each current age. For example, a 70-year old person in Germany is projected to have the health status of a 67-year old person by 2025 and that of a 64-year old person by 2050.

By contrast, in a "pure demographic" scenario, the expenditure curves would not shift rightwards with ageing, reflecting the implicit assumption of unchanged health status at any given age. When these curves stay put in the presence of longevity gains, the share of life lived in 'bad health' increases with life expectancy.

It could be noted that the population projections used in the analysis are pre-determined and do not take into account the effect of health spending on health status and longevity. Making population projections dependent on the level of health spending is beyond the scope of this project and could be the object of further research.

\subsubsection{Non-demographic drivers}

17. As mentioned above, overall demographic drivers explain relatively little of past developments in health spending, even assuming that the expenditure curve by age remains constant (or abstracting from "healthy ageing" effects). Therefore, the non-demographic drivers must play an important role: these are the growth in income and a residual growth component.

18. The effect of real income growth on public health expenditures has been the subject of a vast debate, but the precise value of the income elasticity is still uncertain. Empirical estimates tend to increase with the degree of income aggregation, implying that health care could be "an individual necessity and a national luxury" (Getzen, 2000). However, a high aggregate income elasticity (above unity) often found in macro studies may result from biases in estimates originating from a number of sources, such as failure to appropriately control for quality effects and account for the peculiar statistical properties of some of the variables (see Appendix 3 for more details). Based on the most recent findings from this literature (e.g., Acemoglu et al., 2009 and Holly et al., 2011), as well as estimations carried out for this paper (see Appendices 2 and 3), a real income elasticity equal to 0.8 has been used (a middle point across those estimates) and the sensitivity of the projections to this assumption was subsequently tested (by contrast, OECD (2006) assumed a unitary income elasticity throughout).

19. Once income growth has been accounted for, several factors may explain the residual growth observed in the past: developments in relative prices, technological progress and the features of health institutions and policies. ${ }^{9}$ Nonetheless, it is not feasible at this stage to project these drivers individually. Thus the residual is projected as a whole (as in OECD, 2006) and sensitivity to different assumptions is subsequently tested. Furthermore, a common residual growth is assumed for all countries in order not to extrapolate country-specific idiosyncrasies over a long period (e.g. country-fixed effects). Based on estimates provided in Appendix 2 and Box 3, the projections are based on a benchmark residual expenditure growth of $1.7 \%$ per year. Residual growth over the 2010-2060 period, reflecting non-

9 If projections were done on a component basis (hospital, drugs, ambulatory care, etc.), for some of them a "cost-disease" or Baumol effect may apply as it is the case for LTC (see below). Nonetheless, as this framework is computed for the health sector as a whole, the cost-disease effect could not be assumed. 
demographic, non-income pressures on public health care spending is then assumed to vary around this benchmark across the different projection scenarios (See Table 2.2 below for details).

\subsubsection{Summing up}

20. To summarise graphically the way in which demographic and non-demographic drivers contribute to health care spending (Figure 2.5), the mechanical effect of population ageing on expenditures can be displayed as moving up along the expenditure curve, assuming that the age profile of expenditures remains constant over time (Panel 1). This age factor is then adjusted by incorporating the healthy ageing hypothesis, corresponding to a rightward shift of the curve (Panel 2). This shift implies that older people still cost more than the young, but at progressively older ages. Finally, the expenditure curve may shift upwards $^{10}$ (Panel 3) due to non-demographic drivers (income, the quality-adjusted relative health prices and other unexplained factors, such as policies and institutions).

\section{Box 3. Explaining health care expenditure growth that is unrelated to demographics and income}

Following a large strand of research (See Fuchs (1972); Mushkin and Landefeld (1979); Newhouse (1992); KPMG Consulting (2001); Wanless (2001); Productivity Commission (2005a-b); and Dormont et al., (2006)), this paper explores the idea that the main factors driving the (residual) growth in health care spending that cannot be explained by demographic and income factors are likely to be technology and relative prices. Indeed, the gains in health status discussed above do not only arise from improvements in lifestyle (Sheehan, 2002; Cutler, 2001) but also from advances in medical treatment and health-care technology. The latter, however, do not come free of economic cost. Technical progress can be cost-saving and reduce the relative price of health products and services, but its impact on expenditure will depend on the price elasticity of the demand for health care adjusted for quality effects. If this elasticity is high a fall in prices will induce a more than proportionate rise in demand, increasing expenditures. ${ }^{1}$

As health prices are not easily available, this paper used the value-added deflator in the health and social work sectors, taken from the OECD STAN database (see Appendix 1 for sources and methodology). It is assumed that even if the aggregate covered is broader than the health sector alone, the latter represents the lion's share of the total and the prices in both sectors follow the same path. The health price deflator is expressed as a ratio to the GDP deflator, to generate the relative price index for health services that is used to explain health care expenditures (equation A5 in Appendix 2). A low price elasticity and a steady increase of health prices could explain the rise in expenditures.

It is also difficult to find a good measure for changes in the (technology-induced) quality of health care services. As an (admittedly heroic) assumption, a proxy indicator has, therefore, been constructed, based on a combination of patents and R\&D statistics, which have proved to be good indicators of innovation. The indicator is based on the assumption that the quality of health care tends to increase everywhere with the (global) share of health patents in total patents, but the country-specific increases in quality also depend on R\&D efforts of individual countries reflecting for instance absorption capacity (see Appendix 1 for sources and methodology).

Using these variables and a set of econometric estimates described in Appendix 2, the overall effect of technology and relative prices is estimated to have increased health-care expenditures by $0.8 \%$ per year. In other words, the econometric model is able to explain more than one-third of the past expenditure residual of $2 \%$ per year for the OECD average, displayed in Table 2.1. Estimates suggest that the residual expenditure is also driven by other factors, such as changes in policy and institutions which can be loosely captured by a time trend (Appendix 2). These other factors account for $0.9 \%$ of the increase in health expenditure per year. Overall, these estimates suggest that the residual expenditure has increased health-care expenditures by around $1.7 \%$ (i.e. $0.8 \%+0.9 \%$ ) per year.

The difference between the $2 \%$ growth found in the accounting exercise (Table 2.1 ) and the $1.7 \%$ growth found with the econometric estimate $(0.3 \%)$ remains unexplained. As a consequence, the projections don't take it into account and use $1.7 \%$ as the starting value of the residual expenditure growth.

1. For example, Dormont and Huber (2005) found that in France the unit price of certain surgical treatments, such as cataract removal, decreased, whereas the frequency of the treatment increased significantly. Such effects can explain much of the recent upward shift in the health-care cost curves in France. Duarte (2012) suggest that low price elasticity for health care is difficult to justify.

10 It has to be noted that depending on the type of expenditure this upward shift may be non-homothetic across ages. For example, expenditure at older ages may be more affected by such an upward shift than at younger ones. 
Figure 2.4. Shifts in expenditure profiles, ageing and non-ageing effects

Health expenditure per capita

(1) Pure ageing effect

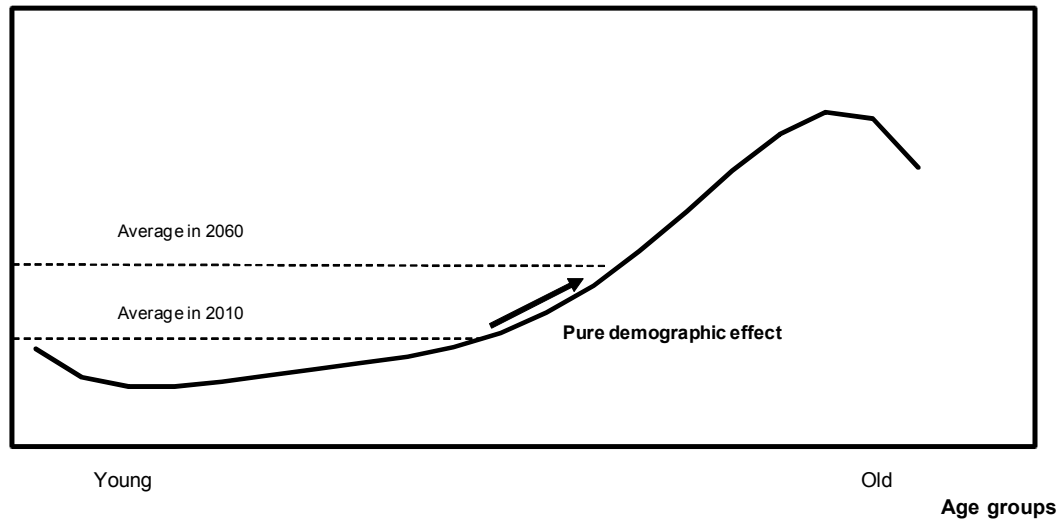

(2) Ageing effect adjusted for death-related costs and healthy longevity Health expenditure per capita

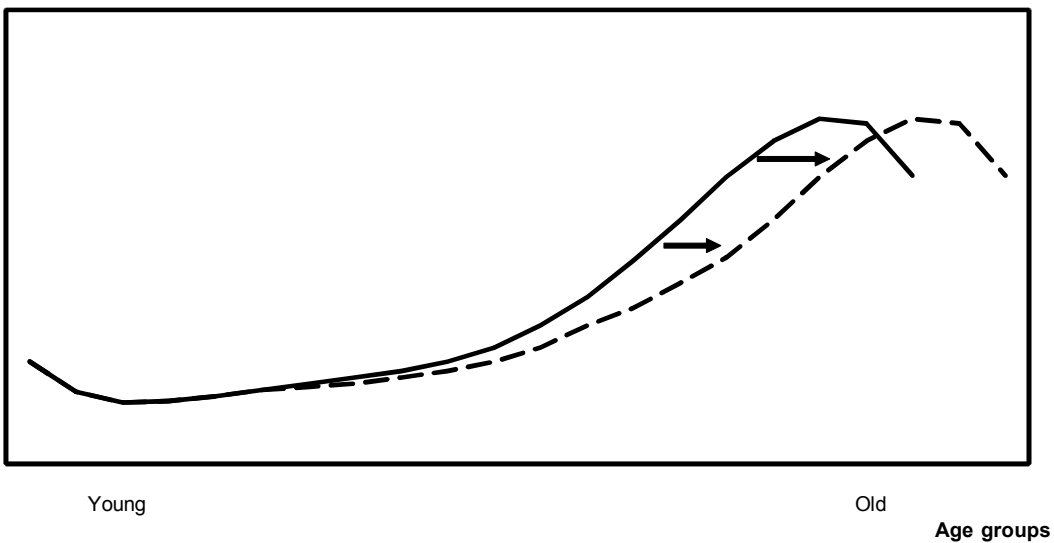

(3) Non-ageing drivers

Health expenditure per capita

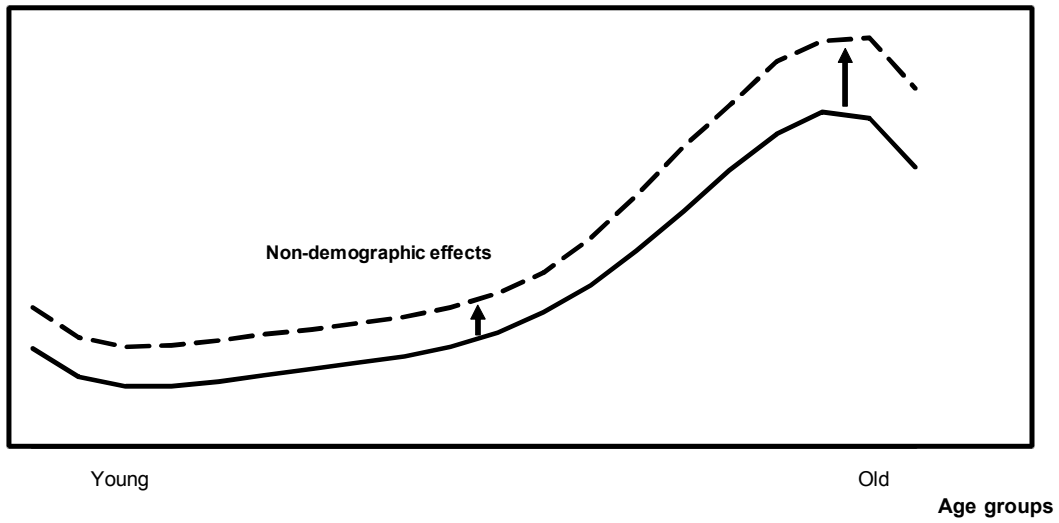


ECO/WKP(2013)40

\subsection{Projection results: public health expenditures, 2010-2060}

21. This section applies the analytical framework to project public health care expenditures in different scenarios over 2010-2060. The main assumptions underlying each scenario are listed in Table 2.2. The section looks first at the demographic and income effects on expenditures and, subsequently, two scenarios regarding the evolution of drivers other than income and demographics (i.e., the residual growth) are analysed. In the "cost pressure scenario" no policy action is undertaken to curb pressures on expenditure whereas the "cost-containment scenario" assumes some policy action to rein in these pressures on expenditures. Even though the nature of such policies is not made explicit, they can be thought of as actions to limit the pressures arising from excessive growth of quality-adjusted relative health prices, e.g., by monitoring more closely the adoption of new technologies or modifying incentives via changes in the governance of health institutions. All these scenarios assume healthy ageing and an income elasticity of 0.8 . Finally, sensitivity analysis is carried out in the context of the cost-containment scenario. More specifically, sensitivity analysis is carried out regarding the value of the income elasticity, the evolution of residual spending growth (i.e. unrelated to income and demographics) and the "healthy ageing" hypothesis. Concerning the latter, results are obtained also in the case of no healthy ageing (i.e. morbidity expands with gains in longevity) and for a more optimistic hypothesis under which each year increase in life expectancy is translated into two years spent in good health.

Table 2.2. Assumptions underlying the alternative projection scenarios: public health care

\begin{tabular}{|c|c|c|c|}
\hline Scenarios & Health status & Income elasticity & Non-demographic, non-income drivers \\
\hline Demographic effect & $\begin{array}{l}\text { Healthy ageing: longevity gains are translated into } \\
\text { equivalent additional years in good health }\end{array}$ & n.a & n.a \\
\hline Cost-pressure scenario & $\begin{array}{l}\text { Healthy ageing: longevity gains are translated into } \\
\text { equivalent additional years in good health }\end{array}$ & Income elasticity $=0.8$ & $\begin{array}{l}\text { The residual is assumed to grow at } 1.7 \% \text { over the } \\
\text { projection period }\end{array}$ \\
\hline Cost-containment scenario & $\begin{array}{l}\text { Healthy ageing: longevity gains are translated into } \\
\text { equivalent additional years in good health }\end{array}$ & Income elasticity $=0.8$ & $\begin{array}{l}\text { The residual growth is } 1.7 \% \text { in the starting period and then } \\
\text { converges to } 0 \text { in } 2060\end{array}$ \\
\hline \multicolumn{4}{|c|}{ Sensitivity analysis based on the cost-containment scenario } \\
\hline Compression of morbidity & $\begin{array}{l}\text { Longevity gains are doubled into additional years in } \\
\text { good health }\end{array}$ & Income elasticity $=0.8$ & $\begin{array}{l}\text { The residual growth is } 1.7 \% \text { in the starting period and then } \\
\text { converges to } 0 \text { in } 2060\end{array}$ \\
\hline Expansion of morbidity & $\begin{array}{l}\text { No health ageing adjustment, i.e longevity gains do } \\
\text { not translate into additional years in good health }\end{array}$ & Income elasticity $=0.8$ & $\begin{array}{l}\text { The residual growth is } 1.7 \% \text { in the starting period and then } \\
\text { converges to } 0 \text { in } 2060\end{array}$ \\
\hline $\begin{array}{l}\text { Country-specific quality } \\
\text { adjusted relative prices }\end{array}$ & $\begin{array}{l}\text { Healthy ageing: longevity gains are translated into } \\
\text { equivalent additional years in good health }\end{array}$ & Income elasticity $=0.8$ & $\begin{array}{l}\text { The residual growth is country specific and converges } \\
\text { to } 0 \text { in } 2060\end{array}$ \\
\hline Income elasticity $=0.6$ & $\begin{array}{l}\text { Healthy ageing: longevity gains are translated into } \\
\text { equivalent additional years in good health }\end{array}$ & Income elasticity $=0.6$ & $\begin{array}{l}\text { The residual growth is } 1.7 \% \text { in the starting period and then } \\
\text { converges to } 0 \text { in } 2060\end{array}$ \\
\hline Income elasticity = 1 & $\begin{array}{l}\text { Healthy ageing: longevity gains are translated into } \\
\text { equivalent additional years in good health }\end{array}$ & Income elasticity = 1 & $\begin{array}{l}\text { The residual growth is } 1.7 \% \text { in the starting period and then } \\
\text { converges to } 0 \text { in } 2060\end{array}$ \\
\hline
\end{tabular}

Note: The key assumption changed in each scenario is in bold.

\subsubsection{Demographic and income effects}

22. As discussed above, demographic effects on public health care expenditures can be decomposed into health care costs for survivors, the adjustment for "healthy ageing" and death-related costs. The pure ageing effect can be quite large in some countries, but tends to be compensated by better health status. Whereas on a per capita basis death-related costs account for the largest part of lifetime expenditures, for the population as a whole they account for only a small fraction of the increase in expenditures as a share of GDP since they concern only the non-survivors.

23. On average, the demographic effect only accounts for a small increase in expenditure. In OECD countries and on its own, it pushes spending from 5.5\% of GDP on average to $6.2 \%$ in 2060. In non-OECD 
countries the demographic effect on its own increases spending from $2.4 \%$ of GDP to $3.4 \%$ in 2060 . While the "healthy ageing" assumption may render the simulation of demographic effects relatively optimistic, this is in line with observed patterns of health status regimes in many OECD countries. It is assumed that the same pattern will apply to non-OECD countries. The effect is projected to apply evenly before and after 2030 for both OECD and non-OECD countries.

24. Interestingly the structure of health expenditure by age changes over the projection period. In $2010,40 \%$ of health expenditure were directed to people aged 65 , and over, with these persons representing $15 \%$ of the population. In 2060 , nearly $60 \%$ of health expenditure will be directed to people aged 65 and over while they will represent $30 \%$ of total population (Figure 2.6). This evolution is only the consequence of demographic effects as non-demographic effects are assumed to affect all age groups in the same proportion (see footnote 11). In other words, while demography is not a main driver of health spending growth, it will induce a significant change in the structure of the spending.

Figure 2.5. Shares of health care expenditure by age in total health care expenditure

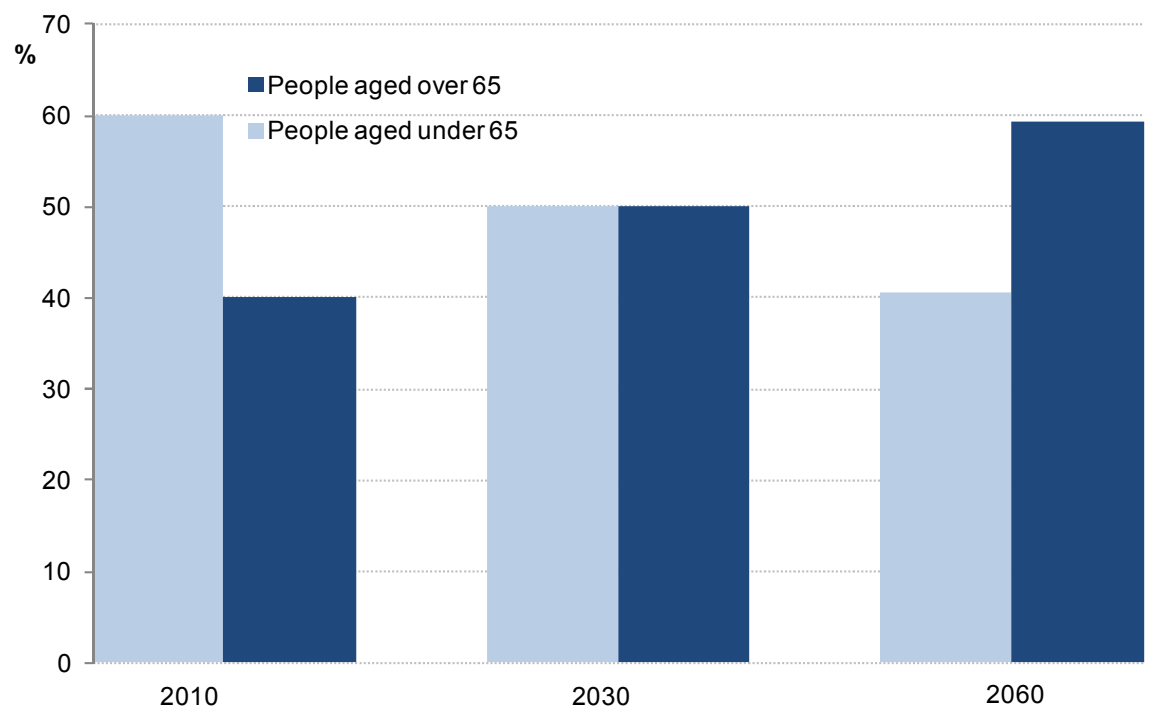

25. The total effect of demographics and income on the increase in public health care expenditures by 2060 is very different across countries (Table 2.3). In OECD countries, the demographic effect ranges from 0.2 percentage points of GDP in Belgium, Iceland and the United Kingdom to more than 1.8 points in Chile, Korea and Turkey. For non-OECD countries it varies from zero in South Africa to 1.7 percentage points of GDP in Brazil and China, reflecting more rapid ageing in the latter two countries.

26. With an assumed less than unitary real income elasticity, the underlying increase in income would imply ceteris paribus a decline in the health expenditure to GDP ratio. As the GDP projections embody a degree of convergence towards living standards of high-income countries (see Box 1), this downward income effect on spending ratios is more important for rapidly catching-up low-income countries. Indeed on average for OECD countries the decline in expenditure ratios due to income growth will amount to -0.8 percentage points while in non-OECD countries it will be -1.4 percentage points. For OECD countries, the average annual decline in ratios due to income will be about the same before and after $2030(\approx-0.02$ percentage points) whereas it will be slightly more important before $2030(\approx-0.04$ percentage points) than after $(\approx-0.03$ percentage points) for non-OECD countries, reflecting the underlying catchingup assumptions for GDP projections. 


\subsubsection{The cost-pressure scenario}

27. As mentioned earlier, in the "cost pressure scenario" it is assumed that on top of the demographic and income effects, health expenditure will grow by a residual $1.7 \%$ per year over the whole projection period. In this scenario, the OECD average health expenditure to GDP ratio is projected to increase by more than 6 percentage points, reaching close to $12 \%$ in 2060 from a starting value of 5.5\% in 2006-2010. The largest increases (above 7 percentage points of GDP) are found in Chile, Korea and Turkey, while the lowest (below 6 percentage points of GDP) are found in Belgium, Denmark, Estonia, Finland, Hungary, Iceland, Sweden and the United Kingdom. Starting from a much lower ratio of health expenditure to GDP at $2.4 \%$, the BRIICS will experience a larger increase as the ratio is set to more than triple, to reach $8.3 \%$. The most important part of these increases is due to the residual component. For both OECD and nonOECD countries, the increase, on average, will be slightly higher in the second part of the projections period. 
Table 2.3. Projection scenarios for public health care expenditure

\begin{tabular}{|c|c|c|c|c|c|c|c|c|c|}
\hline & \multirow[b]{3}{*}{$\begin{array}{c}\text { Average } \\
2006-2010\end{array}$} & \multicolumn{4}{|c|}{ Percentage point deviations from starting period in 2030} & \multicolumn{4}{|c|}{ Percentage point deviations from starting period in 2060} \\
\hline & & \multicolumn{2}{|c|}{$\begin{array}{l}\text { Contributions of demographic } \\
\text { and income effects }\end{array}$} & \multicolumn{2}{|c|}{$\begin{array}{c}\text { Total increase in spending } \\
\text { ratio }\end{array}$} & \multicolumn{2}{|c|}{$\begin{array}{l}\text { Contributions of demographic } \\
\text { and income effects }\end{array}$} & \multicolumn{2}{|c|}{$\begin{array}{c}\text { Total increase in spending } \\
\text { ratio }\end{array}$} \\
\hline & & $\begin{array}{c}\text { Demographic } \\
\text { effect }\end{array}$ & Income effect & $\begin{array}{l}\text { Cost- } \\
\text { pressure }\end{array}$ & \begin{tabular}{c||} 
Cost- \\
containment
\end{tabular} & $\begin{array}{c}\text { Demographic } \\
\text { effect }\end{array}$ & Income effect & $\begin{array}{l}\text { Cost- } \\
\text { pressure }\end{array}$ & $\begin{array}{l}\text { Cost- } \\
\text { containment }\end{array}$ \\
\hline Australia & 5.6 & 0.4 & -0.4 & 2.0 & 1.5 & 0.8 & -0.8 & 6.3 & 2.5 \\
\hline Austria & 6.6 & 0.4 & -0.2 & 2.1 & 1.7 & 0.6 & -0.6 & 6.3 & 2.4 \\
\hline Belgium & 5.8 & 0.2 & -0.3 & 1.8 & 1.4 & 0.2 & -0.7 & 5.8 & 1.9 \\
\hline Canada & 5.8 & 0.6 & -0.3 & 2.2 & 1.8 & 0.7 & -0.7 & 6.3 & 2.5 \\
\hline Chile & 3.1 & 0.9 & -0.6 & 2.3 & 1.8 & 1.8 & -1.1 & 7.1 & 3.2 \\
\hline Czech Republic & 5.5 & 0.4 & -0.5 & 1.9 & 1.4 & 0.7 & -0.9 & 6.1 & 2.2 \\
\hline Denmark & 6.3 & 0.4 & -0.2 & 2.1 & 1.6 & 0.3 & -0.7 & 5.9 & 2.0 \\
\hline Estonia & 4.3 & 0.2 & -0.5 & 1.6 & 1.1 & 0.6 & -1.1 & 5.8 & 2.0 \\
\hline Finland & 5.2 & 0.4 & -0.3 & 2.0 & 1.5 & 0.3 & -0.7 & 5.9 & 2.0 \\
\hline France & 7.4 & 0.3 & -0.3 & 1.9 & 1.4 & 0.3 & -0.6 & 6.1 & 2.2 \\
\hline Germany & 7.3 & 0.5 & -0.3 & 2.1 & 1.6 & 0.6 & -0.7 & 6.2 & 2.3 \\
\hline Greece & 5.4 & 0.3 & -0.3 & 1.9 & 1.4 & 0.7 & -0.6 & 6.4 & 2.5 \\
\hline Hungary & 4.8 & 0.2 & -0.5 & 1.6 & 1.2 & 0.4 & -1.0 & 5.8 & 1.9 \\
\hline Iceland & 5.8 & 0.3 & -0.2 & 2.0 & 1.5 & 0.2 & -0.7 & 5.9 & 2.0 \\
\hline Israel & 4.0 & 0.3 & -0.2 & 2.0 & 1.5 & 0.7 & -0.7 & 6.4 & 2.5 \\
\hline Ireland & 5.5 & 0.3 & -0.2 & 2.1 & 1.6 & 0.5 & -0.5 & 6.4 & 2.5 \\
\hline Italy & 6.1 & 0.3 & -0.2 & 2.1 & 1.6 & 0.7 & -0.6 & 6.4 & 2.6 \\
\hline Japan & 6.1 & 0.6 & -0.3 & 2.3 & 1.8 & 0.8 & -0.8 & 6.3 & 2.5 \\
\hline Korea & 3.3 & 1.1 & -0.5 & 2.6 & 2.1 & 2.0 & -0.8 & 7.6 & 3.7 \\
\hline Luxembourg & 4.4 & 0.4 & -0.1 & 2.2 & 1.7 & 0.7 & -0.2 & 6.9 & 3.0 \\
\hline Mexico & 2.5 & 0.6 & -0.5 & 2.1 & 1.6 & 1.6 & -1.1 & 6.9 & 3.0 \\
\hline Netherlands & 6.4 & 0.6 & -0.3 & 2.2 & 1.8 & 0.7 & -0.7 & 6.3 & 2.4 \\
\hline New Zealand & 6.4 & 0.5 & -0.3 & 2.1 & 1.6 & 0.8 & -0.9 & 6.3 & 2.4 \\
\hline Norway & 5.1 & 0.3 & -0.4 & 1.9 & 1.4 & 0.5 & -0.7 & 6.1 & 2.2 \\
\hline Poland & 4.1 & 0.4 & -0.5 & 1.9 & 1.4 & 1.0 & -0.9 & 6.4 & 2.6 \\
\hline Portugal & 6.5 & 0.4 & -0.2 & 2.0 & 1.6 & 0.8 & -0.7 & 6.5 & 2.6 \\
\hline Slovak Republic & 5.4 & 0.5 & -0.5 & 1.9 & 1.5 & 1.1 & -0.9 & 6.5 & 2.6 \\
\hline Slovenia & 5.2 & 0.5 & -0.3 & 2.1 & 1.7 & 1.0 & -0.8 & 6.6 & 2.7 \\
\hline Spain & 5.6 & 0.4 & -0.3 & 2.0 & 1.6 & 1.0 & -0.6 & 6.7 & 2.8 \\
\hline Sweden & 6.6 & 0.2 & -0.3 & 1.8 & 1.3 & 0.3 & -0.7 & 5.9 & 2.0 \\
\hline Switzerland & 5.7 & 0.4 & -0.3 & 2.1 & 1.6 & 0.9 & -0.8 & 6.5 & 2.6 \\
\hline Turkey & 3.8 & 0.7 & -0.6 & 2.0 & 1.5 & 1.8 & -1.1 & 7.0 & 3.1 \\
\hline United Kingdom & 6.5 & 0.2 & -0.2 & 1.9 & 1.4 & 0.2 & -0.7 & 5.9 & 2.0 \\
\hline United States & 7.1 & 0.4 & -0.3 & 2.0 & 1.5 & 0.5 & -0.7 & 6.1 & 2.2 \\
\hline OECD average ${ }^{1}$ & 5.5 & 0.4 & -0.3 & 2.0 & 1.6 & 0.8 & -0.8 & 6.3 & 2.5 \\
\hline Brazil & 3.7 & 0.8 & -0.6 & 2.1 & 1.6 & 1.7 & -1.1 & 7.0 & 3.1 \\
\hline China & 1.9 & 0.9 & -1.1 & 1.7 & 1.3 & 1.7 & -1.7 & 6.4 & 2.5 \\
\hline India & 1.2 & 0.3 & -1.0 & 1.3 & 0.8 & 0.9 & -1.7 & 5.5 & 1.6 \\
\hline Indonesia & 1.2 & 0.6 & -0.8 & 1.7 & 1.3 & 1.3 & -1.5 & 6.2 & 2.3 \\
\hline Russia & 3.1 & 0.1 & -0.6 & 1.5 & 1.0 & 0.2 & -1.0 & 5.5 & 1.6 \\
\hline South Africa & 3.2 & 0.0 & -0.6 & 1.4 & 0.9 & 0.0 & -1.2 & 5.2 & 1.3 \\
\hline Non-OECD average ${ }^{1}$ & 2.4 & 0.5 & -0.8 & 1.6 & 1.2 & 1.0 & -1.4 & 5.9 & 2.1 \\
\hline Total average $^{1}$ & 5.0 & 0.4 & -0.4 & 2.0 & 1.5 & 0.8 & -0.8 & 6.3 & 2.4 \\
\hline
\end{tabular}

1. Unweighted average.

Source: Authors' calculations.

\subsubsection{The cost-containment scenario}

28. While the cost-pressure projections may be useful as a benchmark, they do not seem very plausible. It is unlikely that public health-care expenditures to GDP could continue to grow at such rates, without limit. For instance, regarding drugs, the following policies can help containing the costs: a more intense use of generics, a revision of re-imbursement practices for drugs with low medical service (and more stringent restrictions on exemptions to this rule), a more frequent re-evaluation of prices of new drugs (in general a more transparent and dynamic pricing of new drugs), centralised bargaining for the purchase 
of drugs and medical goods in public hospitals, reduction in excessive consumption of specific drugs. Regarding in-patient care, shorter length of stay, development of ambulatory hospitalisation or more user choice among health providers could help reining in the expenditure growth. Regarding out-patient care, a more stringent health monitoring of patients affected by long-term diseases in order to reduce costly complications; financial incentives set on general practitioners to reduce prescription inflation and enhance prevention could also help maintaining the health expenditure on a sustainable path.

29. Accordingly, a long-run convergence condition is considered in the cost-containment scenario. Specifically, the growth contribution of the spending residual, whose past growth was partly attributable to technology and relative price effects (Box 3), is assumed to converge to zero in 2060, implicitly representing the assumption that policies are more effective than in the past in controlling the expenditure growth driven by non-demographic non-income related factors.

30. In this scenario (Table 2.3), the health expenditure to GDP ratio for OECD countries would increase by 2.5 percentage points, to reach close to $8 \%$ on average by 2060 . The largest increases (above 3 percentage points of GDP) are found in Chile, Korea, Luxembourg, Mexico and Turkey. The lowest increases (below 2 percentage points of GDP) are found in Estonia, Hungary, Sweden and the United Kingdom. The increase in non-OECD countries averages around 2 percentage points, to reach $4.5 \%$ of GDP by 2060 . The effect of non-demographic non-income factors is higher before 2030 than after for all countries, as the residual growth is assumed to converge to zero over the projection period. The difference between cost-pressure and cost-containment scenarios increases over time due to compounding effect of the residual.

\subsubsection{Sensitivity analysis}

31. In the sensitivity analysis, a number of parameters were changed in the context of the "costcontainment scenario": the income elasticity, the residual spending growth, as well as factors underlying health status at old age (Table 2.4). Detailed results for all scenarios are provided in Appendix 5. Overall, the previous results seem relatively robust. Specifically, these alternative simulations do not change qualitatively the picture emerging from the comparison of the "cost-pressure" and "cost-containment" scenarios discussed above.

32. First, given that assumptions on the future evolution of the residual are necessarily arbitrary, their impact on projections was checked by computing a cost-containment scenario in line with the assumptions behind such a scenario in the previous 2006 OECD projections. In this variant (not shown in the table), on top of the demographic and income effects, the residual component is assumed to contribute $1 \%$ per year, tending towards $0 \%$ in 2060 . On average, the health expenditure to GDP ratio across OECD countries reaches $6.8 \%$ instead of $7.9 \%$ in this new exercise. For non-OECD countries, the ratio will reach $3.3 \%$ instead of $4.4 \%$. As the assumption underlying this scenario is common for all countries, the percentage point deviation from cost-containment scenario is the same for all countries (-1.1). However, the assumptions behind this scenario may be overly optimistic: the lower value of the residual growth contribution in the 2006 exercise reflected in part a higher income elasticity which arithmetically left less of historical spending growth to be explained by the residual. Assuming both lower income elasticity than in the 2006 exercise and a similar residual spending component may be too much to hope for. 
Table 2.4. Sensitivity analysis on public health care projections

(Performed on the cost-containment scenario)

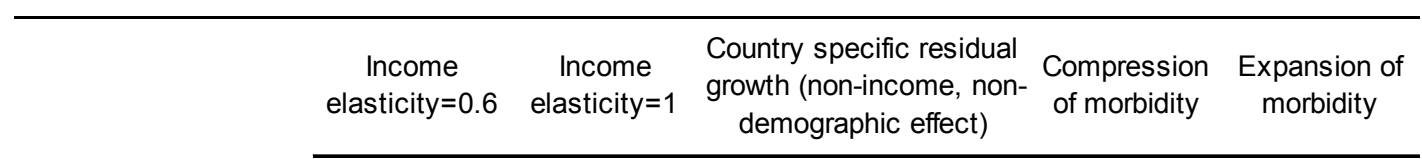

Percentage point deviations from cost-contaiment scenario in 2060

\begin{tabular}{|c|c|c|c|c|c|}
\hline & & & & & \\
\hline Australia & -0.7 & 0.8 & 9.9 & -0.6 & 0.6 \\
\hline Austria & -0.5 & 0.6 & 6.4 & -0.7 & 0.9 \\
\hline Belgium & -0.6 & 0.7 & 0.2 & -0.6 & 0.8 \\
\hline Canada & -0.6 & 0.7 & 1.0 & -0.5 & 0.7 \\
\hline Chile & -0.8 & 1.1 & 0.0 & -0.6 & 0.7 \\
\hline Czech Republic & -0.8 & 0.9 & -4.0 & -0.8 & 1.0 \\
\hline Denmark & -0.6 & 0.7 & 5.4 & -0.7 & 0.8 \\
\hline Estonia & -0.9 & 1.1 & 0.0 & -0.7 & 0.8 \\
\hline Finland & -0.6 & 0.7 & 4.0 & -0.7 & 0.7 \\
\hline France & -0.5 & 0.6 & -2.4 & -0.6 & 0.8 \\
\hline Germany & -0.6 & 0.7 & -0.7 & -0.7 & 0.9 \\
\hline Greece & -0.5 & 0.6 & 2.9 & -0.6 & 0.8 \\
\hline Hungary & -0.8 & 1.0 & -1.9 & -0.9 & 1.3 \\
\hline Iceland & -0.6 & 0.7 & 15.7 & -0.5 & 0.6 \\
\hline Israel & -0.6 & 0.7 & 0.0 & -0.5 & 0.7 \\
\hline Ireland & -0.4 & 0.5 & 0.0 & -0.7 & 0.8 \\
\hline Italy & -0.5 & 0.6 & -1.8 & -0.6 & 0.7 \\
\hline Japan & -0.6 & 0.8 & 0.0 & -0.6 & 0.7 \\
\hline Korea & -0.7 & 0.8 & 0.5 & -0.7 & 0.8 \\
\hline Luxembourg & -0.2 & 0.2 & -0.9 & -0.7 & 0.9 \\
\hline Mexico & -0.8 & 1.1 & 0.0 & -0.7 & 0.9 \\
\hline Netherlands & -0.6 & 0.7 & -2.7 & -0.6 & 0.8 \\
\hline New Zealand & -0.7 & 0.9 & 2.0 & -0.6 & 0.6 \\
\hline Norway & -0.6 & 0.7 & -1.6 & -0.6 & 0.7 \\
\hline Poland & -0.7 & 0.9 & -5.3 & -1.0 & 1.3 \\
\hline Portugal & -0.6 & 0.7 & 8.7 & -0.8 & 0.9 \\
\hline Slovak Republic & -0.8 & 0.9 & -6.5 & -1.0 & 1.4 \\
\hline Slovenia & -0.6 & 0.8 & 0.0 & -0.7 & 0.7 \\
\hline Spain & -0.5 & 0.6 & 5.8 & -0.7 & 0.8 \\
\hline Sweden & -0.6 & 0.7 & -0.4 & -0.6 & 0.7 \\
\hline Switzerland & -0.6 & 0.8 & 1.1 & -0.6 & 0.8 \\
\hline Turkey & -0.8 & 1.1 & 0.0 & -0.8 & 1.0 \\
\hline United Kingdom & -0.6 & 0.7 & -2.3 & -0.6 & 0.7 \\
\hline United States & -0.6 & 0.7 & -1.6 & -0.6 & 0.6 \\
\hline OECD average ${ }^{1}$ & -0.6 & 0.8 & 0.9 & -0.7 & 0.8 \\
\hline Brazil & -0.9 & 1.1 & 0.0 & -0.8 & 1.0 \\
\hline China & -1.1 & 1.7 & 0.0 & -0.8 & 1.1 \\
\hline India & -1.1 & 1.7 & 0.0 & -0.8 & 1.2 \\
\hline Indonesia & -1.0 & 1.5 & 0.0 & -0.9 & 1.3 \\
\hline Russia & -0.8 & 1.0 & 0.0 & -0.7 & 1.0 \\
\hline South Africa & -0.9 & 1.2 & 0.0 & -0.6 & 1.4 \\
\hline Non-OECD average ${ }^{1}$ & -1.0 & 1.4 & 0.0 & -0.8 & 1.2 \\
\hline Total average ${ }^{1}$ & -0.7 & 0.8 & 0.8 & -0.7 & 0.9 \\
\hline
\end{tabular}

1. Unweighted average.

Source: Authors' calculations. 
33. As noted above and in Appendix 3, there is considerable uncertainty concerning the income elasticity of health spending. The sensitivity analysis is carried out taking plus and minus two standard deviations from the value estimated in the benchmark regressions, corresponding to an income elasticity equal to 0.6 and 1 respectively. When the income elasticity is set to one, on average for OECD countries the health expenditure deviation from base case will be 0.8 percentage points of GDP to reach $8.7 \%$. It is slightly higher for non-OECD countries at 1.4 percentage points of GDP. In both groups of countries, those with the largest projected GDP per capita growth are obviously the most affected by changes in the income elasticity. When the income elasticity is set to 0.6 , health expenditure deviates from base case by 0.6 percentage points of GDP on average in OECD countries, to reach $7.3 \%$. This deviation is much higher in non-OECD countries, amounting to -1 percentage point of GDP.

34. Sensitivity to alternative health status was also explored. In an "expansion of morbidity" scenario, the share of life spent in ill health would increase as life expectancy increases (e.g. an increase in the survival rates of sick people), while a "compression of morbidity" scenario would mean the opposite (e.g. an improvement in the health status and health behaviour of the new cohorts of old people). Under these scenarios, by 2060 average health expenditures in OECD countries range from 7.2 to $8.7 \%$ of GDP. In non-OECD countries, they range from $3.7 \%$ to $5.6 \%$. Thus, while alternative health regimes matter for projecting future expenditure trends, their impact on projections is smaller than that of non-demographic effects.

35. It has to be acknowledged that convergence across countries will probably occur for total (public and private) rather than public spending. However, the way the convergence is implemented in this framework makes it difficult to justify the implementation of convergence in total spending in the projections. Specifically, private expenditure on health is likely to be driven by factors that are not taken into account in our analysis. Convergence in public expenditure ratios is a relatively transparent (though debatable) policy assumption, while convergence in total expenditure would require additional assumptions on private behaviour. Nonetheless a sensitivity analysis has been carried out on the basis of convergence for total spending.

36. As can be seen from Table 2.5, in most cases except notably for the United States, this would entail higher estimates in 2060, in both scenarios, the differences being even much larger in the costpressure scenario. As a consequence, it would seem likely that the convergence assumption adopted in this paper could lead to an overestimation of expenses for countries (such as the United States) that have so far relied more on private expenditures. 
Table 2.5. Health expenditure as a \% of GDP in 2060

\begin{tabular}{lcc|cc}
\hline & \multicolumn{2}{c|}{ Cost-containment scenario } & \multicolumn{2}{c}{ Cost-pressure scenario } \\
\hline & $\begin{array}{c}\text { Public } \\
\text { expenditure } \\
\text { convergence }\end{array}$ & $\begin{array}{c}\text { Total } \\
\text { expenditure } \\
\text { convergence }\end{array}$ & $\begin{array}{c}\text { Public } \\
\text { expenditure } \\
\text { convergence }\end{array}$ & $\begin{array}{c}\text { Total } \\
\text { expenditure } \\
\text { convergence }\end{array}$ \\
\hline Austria & 9.1 & 9.5 & 12.9 & 14.1 \\
Belgium & 7.7 & 7.6 & 11.6 & 11.6 \\
Denmark & 8.3 & 8.5 & 12.2 & 13.1 \\
France & 9.6 & 9.8 & 13.5 & 14.2 \\
Germany & 9.6 & 10.0 & 13.5 & 14.6 \\
Hungary & 6.7 & 6.4 & 10.6 & 9.9 \\
Iceland & 7.8 & 7.9 & 11.7 & 12.3 \\
Israel & 6.6 & 6.4 & 10.4 & 10.1 \\
Ireland & 8.0 & 8.4 & 11.9 & 12.8 \\
Japan & 8.6 & 9.1 & 12.5 & 13.9 \\
Luxembourg & 7.4 & 8.9 & 11.3 & 14.9 \\
Netherlands & 8.8 & 9.3 & 12.7 & 14.1 \\
Spain & 8.5 & 8.9 & 12.3 & 13.7 \\
United Kingdom & 8.5 & 9.0 & 12.4 & 14.1 \\
United States & 9.3 & 8.6 & 13.2 & 11.4 \\
\hline & & & & \\
\hline
\end{tabular}

Source: Authors' calculations.

\section{Long-term care}

37. Long-term care differs radically from health care. While health care services aim at changing the health condition (from unwell to well), LTC merely aims at making the current condition (unwell) more bearable. Individuals need LTC due to disability, chronic condition, trauma, or illness, which limit their ability to carry out basic self-care or personal tasks that must be performed each day. Such activities are defined as activities of daily living (ADLs), which embrace eating, dressing, bathing, getting in and out of bed, toileting and continence or instrumental activities of daily living (IADLs), which include preparing own meals, cleaning, laundry, taking medication, getting to places beyond walking distance, shopping, managing money affairs and using the telephone/internet. A person is dependent if he or she has limitations in ADLs or IADLs.

38. It should be noted that LTC also includes a small part of health services that are thus not accounted for in health care. Indeed, total LTC spending is calculated as the sum of health care and social services for those in LTC (Colombo et al., 2011)). Health-related LTC spending includes palliative care, long-term nursing care, personal care services, and health services in support of family care. Social services provided for LTC include home help (e.g., domestic services) and care assistance, residential care services, and other social services. In other words, the health component of LTC spending includes episodes of care where the main need is either medical or personal care services (ADL support), while services whose dominant feature is help with IADL are considered outside the health-spending boundaries.

39. A striking difference between spending on health and LTC is that the cost of LTC per beneficiary is roughly independent of age (Figure 3.1). Indeed, the cost of helping one person in ADLs or IADLs could be more or less the same, irrespective of their age. Moreover, while potentially the entire population may benefit from health care, only dependent persons will benefit from LTC. Therefore, while the age-specific 
cost curve for health care was expressed per capita for each age group, that for LTC is expressed per dependant.

Figure 3.1. Public long-term care expenditure per beneficiary as a $\%$ of GDP per capita ${ }^{1}$

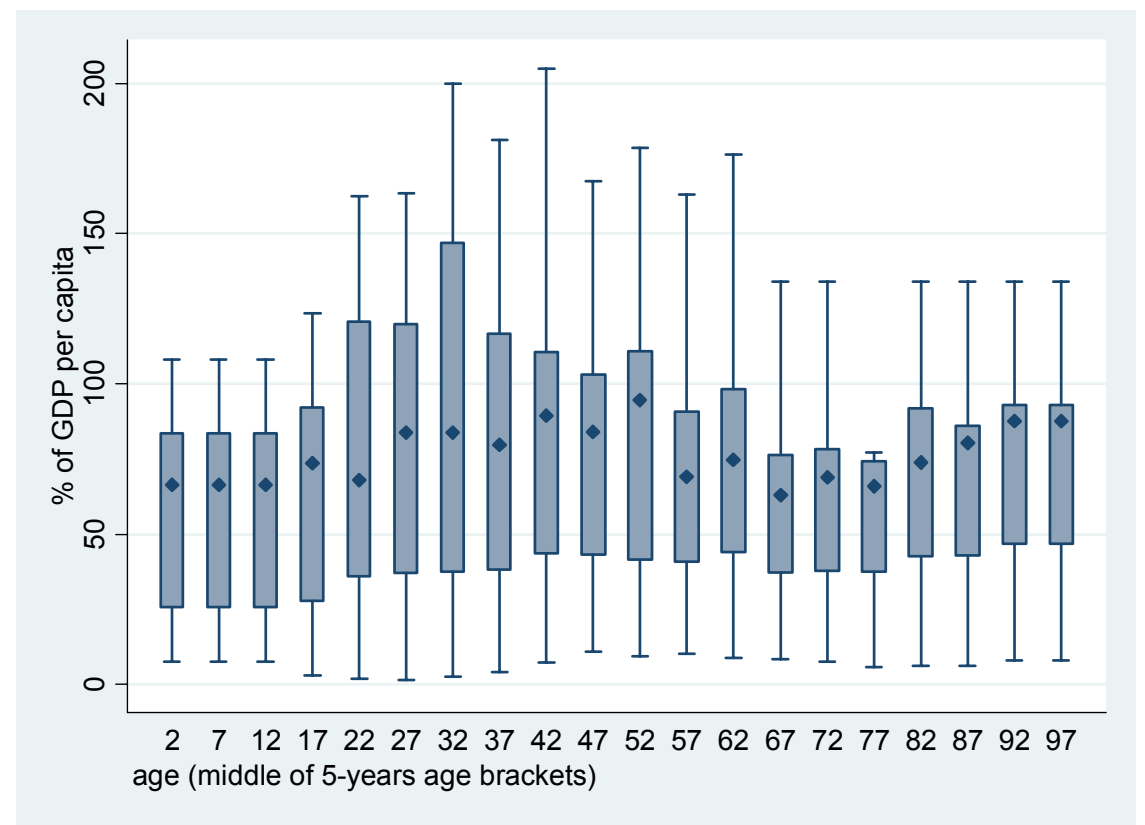

1. The graph shows the dispersion of long-term care expenditure across countries by age groups. The diamonds represent the median. The boxes are the $2^{\text {nd }}$ and $3^{\text {rd }}$ quartiles of the distribution of expenditure across countries. The whiskers are the $1^{\text {st }}$ and $4^{\text {th }}$ quartiles.

Source: European Commission, 2009 Ageing Report: Economic and budgetary projections for the EU-27 Member States (20082060).

40. As for health care, two kinds of determinants drive LTC expenditure, demographic and nondemographic (Figure 3.2). The demographic driver is related to the number of dependent people in the population. The evolution of this factor depends on the evolution of life expectancy and health expenditure. The non-demographic drivers are related to income developments and changes in the demand for publicfinanced LTC services. Income is assumed to have a direct effect via increases in living standards (GDP per capita) and an indirect effect via cost-disease (relative productivity or Baumol) effects. Given the importance of home production of LTC services, the demand for public spending on LTC is assumed to depend on developments in formal labour force participation. 
Figure 3.2. The determinants of LTC expenditure

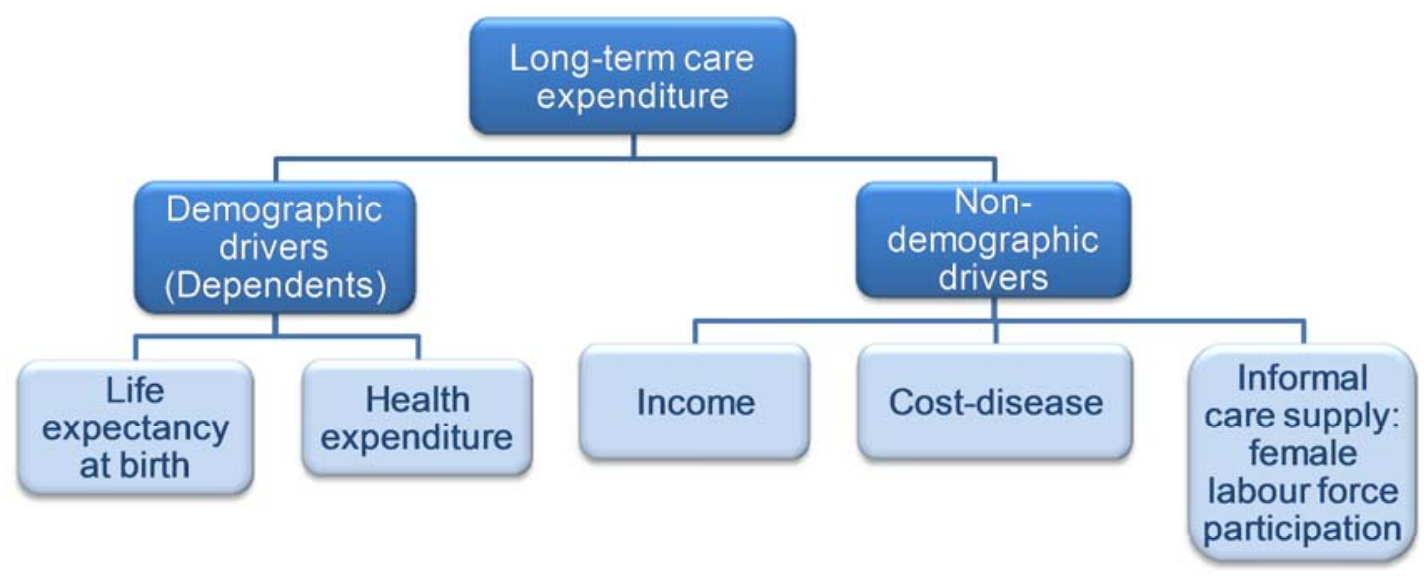

\subsection{Projection framework}

41. The framework used to project public LTC expenditure distinguishes between demographic and non-demographic drivers. The evolution of each driver is projected separately. They are then combined to compute the future growth of total LTC expenditure. The basic projection equation can be interpreted as a reduced form combining demand and supply factors that determine equilibrium LTC expenditures. More details on these assumptions and the corresponding variable definitions are provided below and in Appendix 1, but adopting the same notation as in equation (1) the projection equation for LTC spending ratios is the following:

$$
\Delta \log \left(\frac{L T C}{P_{Y} . Y}\right)=\Delta \log (\text { Demo })+(\varepsilon-1) \cdot \Delta \log \left(\frac{Y}{N}\right)+\gamma \cdot \Delta \log (\text { Baumol })+\delta \cdot \Delta \log (\text { Participation })
$$

where Demo stands for demographic effects which in the case of LTC stand for the number of dependent people; Baumol stands for the cost-disease effect captured by the labour productivity differential between the LTC sector and the rest of the economy, with an elasticity of $\gamma$ that can take the value of 1 or 0.5 depending on the scenario ( 0.5 or 0.25 for the BRIICS); Participation is a proxy for the increase of public formal care, with an estimated elasticity of 0.7 (see Appendix 4); and $\varepsilon$ is the income elasticity of LTC expenditures that can take the value of 1 or 2 . As for health care, the elasticities are estimated econometrically (see Box 5 and Appendix 4).

42. The total logarithmic growth rates are first projected for each country. Applying the same methodology as for health care, those growth rates are then adjusted to allow for a certain convergence of LTC expenditure to GDP ratio across countries. Therefore, each country-specific growth rate is multiplied by the ratio of the average initial expenditure ratio across countries to the country-specific initial ratio. In order to smooth out the impact of the recent crisis on expenditure, the starting point for each country is computed as the average share of public LTC spending in GDP over 2006-2010.

\subsubsection{Demographic drivers of expenditure}

43. Whereas health care projections distinguished between survivors and non-survivors, the LTC projections split each age group into dependants and non-dependants. The age-specific dependency ratios 
have been estimated by the European Commission for 22 European countries (Ageing Report 2009). Even if the shape of the dependency ratios by age differs across countries, the dispersion remains relatively limited (Figure 3.3). Thus, as a first approximation, dependency ratios (number of dependants by age group) are assumed to be broadly uniform across countries. For the purpose of projecting expenditure, this also has the advantage of eliminating current differences in the prevalence of dependency across countries as a possible cause for future differential increases in LTC expenditures. In other words, the projections become less sensitive to initial conditions. Noteworthy, this assumption therefore abstracts from the influence of differences in policy settings on these initial conditions.

44. For the calculation of the pure demographic effect (Demo in equation 2), it is assumed that the LTC spending per dependant remains constant. Thus, the variation in LTC expenditure resulting from the pure demographic effect is only driven by the increase in the number of dependants by age group. The latter is derived from the average age-specific dependency ratio (see above) multiplied by the population by age group.

45. An important driver of the prevalence of dependency is the evolution of life expectancy. As life expectancy at birth is increasing and translates into years in good health ("healthy ageing" hypothesis), the prevalence of dependency occurs later in life. As a result, dependency is reduced at younger age. But improving the health status may have an opposite impact on the prevalence of dependency. Indeed, if an increase in health expenditure translates into higher longevity at every age, and especially at older age, it may translate into an increase in the prevalence of chronic diseases in older age (Goldman et al., 2005). The latter, in turn, increases the probability of dependency. This potentially creates a link between spending on health care, health status and LTC.

Figure 3.3. Dependency ratios by age ${ }^{1}$

(Number of dependants as a \% of population by age groups)

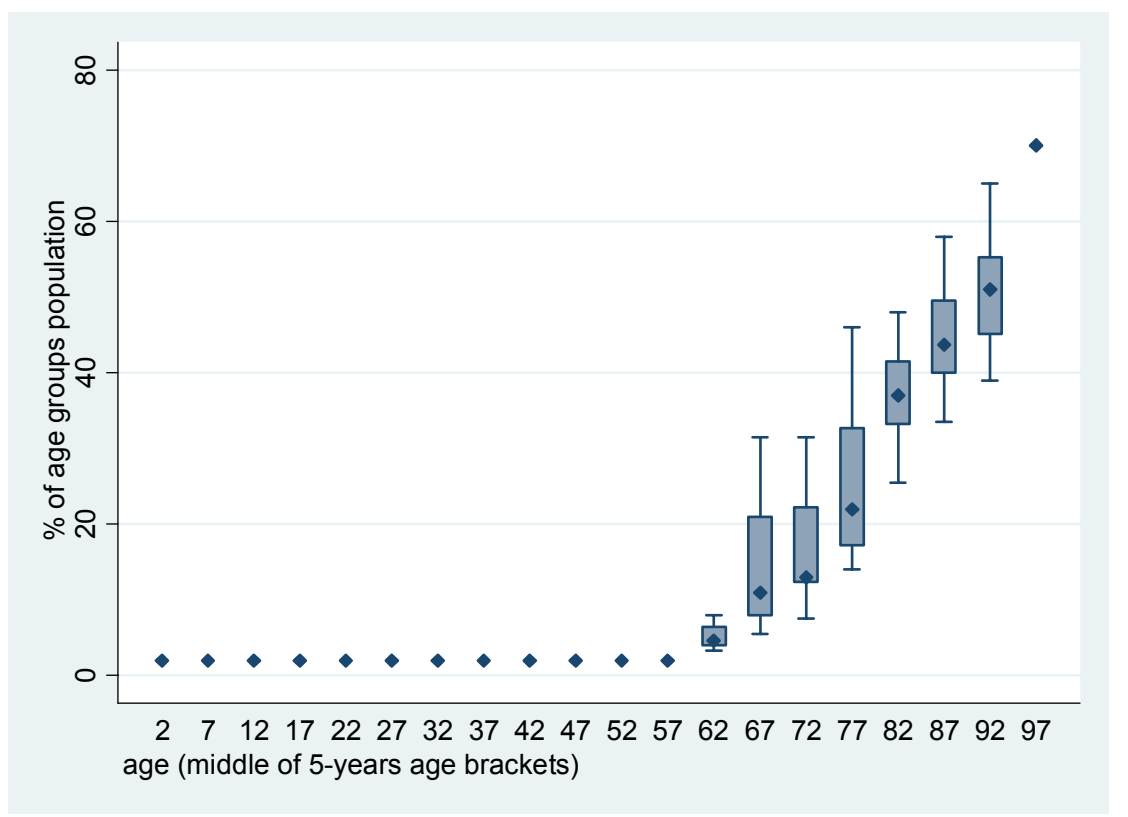

1. The graph shows the dispersion of dependency ratio across countries by age groups. The diamonds represent the median. The boxes are the $2^{\text {nd }}$ and $3^{\text {rd }}$ quartiles of the distribution of expenditure across countries. The whiskers are the $1^{\text {st }}$ and $4^{\text {th }}$ quartiles.

Source: European Commission, 2009 Ageing Report: Economic and Budgetary Projections for the EU-27 Member States (20082060). 
46. In order to project the evolution of dependency until 2060 taking into account the possible link between dependency and health-care expenditures, the age-specific dependency ratios have been estimated based on historical data as a function of age, age-specific per capita health-care expenditures and life expectancy at birth (see Box 4). Consistent with the healthy-ageing hypothesis, dependency at old age is found to decline over time. But the decline of the dependency ratio by age group depends in turn on the evolution of life expectancy at birth and per capita public health care expenditures (as projected in the costcontainment scenario for health-care).

47. Accounting for the influence of health-care expenditure on the dependency ratio generates a link between the health-care and LTC projections even though the two spending items are projected separately. Clearly, this link may materialise with a lag, which is however difficult to ascertain empirically, especially in the context of the mostly cross-section data used in this paper. Therefore, a contemporaneous link is assumed for simplicity.

\section{Box 4. Dependency ratio estimates}

In order to gauge the evolution of the dependency ratio, its past determinants have been investigated by means of panel regression techniques. Defining $D e p r_{i, a}$ as the dependency ratio (number of dependent people for country $i$ and age a), Age as the central point in each age bracket $(2,7,12, \ldots, 97), h e_{i, a}$ the real public health care expenditure per capita for country $i$ and age $a$ and $L E_{i}$ life expectancy at birth for country $i$, the following equation was estimated:

$$
\log \left(\operatorname{Depr}_{i, a}\right)=\propto+\varphi * \log \left(A g e_{i}\right)+\beta * \log (\text { he })_{\mathrm{i}, \mathrm{a}}+\gamma * \log \left(\mathrm{LE}_{\mathrm{i}}\right)+u_{i, a}
$$

The equation was estimated for the population aged 52 and above, as the dependency ratio for people below 52 is small and roughly constant over time. As expected, the age variable has a highly significant, positive impact (See Table A4.1 in Appendix 4). Public health expenditure per capita also has a significant positive effect, though much smaller. Conversely, increased life expectancy at birth delays the prevalence of dependency.

Including life expectancy at birth minimises the possibility that this effect could be driven by health expenditures themselves, thereby avoiding multicollinearity problems between health expenditure and life expectancy.

\subsubsection{Non-demographic drivers of expenditure}

48. Apart from the evolution of the number of dependants in the population, non-demographic drivers also have an impact on LTC expenditure growth. The projections account for three of them: changes in the relative price of LTC, income effects and changes in the demand for public-financed LTC, which in turn depend on the availability of informal care.

49. One of the main non-demographic drivers of public LTC expenditure is the relative share of informal and formal care. ${ }^{1112}$ Most informal care is provided by family and friends (Colombo et al., 2011).

$11 \quad$ Formal care is provided by care assistants who are paid for providing care under some form of employment contract. It includes both care provided in institutions and care provided at home. To be considered informal, the provision of care cannot be paid for as if purchasing a service. However, an informal caregiver may still receive social transfers conditional on his/her provision of informal care and possibly, in practice, some informal payment from the person receiving care.

12 The projections do not distinguish between formal care delivered within institutions and that delivered to the patient's home. There are fundamental differences between countries in the way they organise their formal LTC. Institutional LTC is particularly widespread in the Nordic countries (OECD, 2005). Whether this form of organisation is adopted by other countries or a (cheaper) ambulatory help-at-home strategy is pursued could have important consequences for public expenditures. 
Even using a narrow definition of the family care "workforce", its size is at least twice that of the formal care workforce (e.g., in Denmark), and in some cases it is estimated to be more than ten times the size of the formal-care workforce (e.g., Canada, New Zealand, the United States, the Netherlands). On average, around $70 \%$ to $90 \%$ of those who provide care are family carers (Fujisawa and Colombo, 2009). Changing societal models - such as declining family size, changes in residential patterns of people with disabilities and rising female participation in the formal labour market - are likely to contribute to a decline in the availability of informal care-givers, leading to an increase in the need for paid care (Colombo et al., 2011). Since there is evidence that informal elderly care is associated with lower female labour force participation (Viitanen, 2005), informal carers have been proxied by the labour force participation of women aged 50-64 to project the future evolution of LTC spending (a sensitivity check has also been carried out using their exit rate from the labour force). As participation rates by age and gender are not readily available for nonOECD countries, informal carers have been proxied by the overall participation rates in these countries.

50. Another important non-demographic driver of public LTC expenditure is a "cost disease" or Baumol effect (Baumol, 1967; 1993). The LTC sector is highly labour-intensive and the room for productivity gains is often seen as more limited than elsewhere in the economy. With equalisation of wages across sectors, this implies that the relative price of LTC vis-à-vis other goods and services in the economy, tends to rise as aggregate productivity and GDP per capita increase. With a price-inelastic demand, the share of LTC expenditure in GDP would, therefore, tend to increase over time. A possible way to capture this effect is to assume that unit costs rise in line with average earnings of care staff or a measure of wage inflation in the economy (Comas-Herrera et al., 2003). In this paper, productivity growth in the total economy has been used as a proxy for the Baumol effect on public LTC expenditures. ${ }^{13}$

51. Finally, income is also likely to play a role in LTC expenditure. Indeed, as real incomes rise, demand may be directed at higher quality services (Colombo et al., 2011), thereby increasing expenditures. Figure 3.4 shows a positive relationship between income and public LTC expenditure with an elasticity above one. It is difficult however to distinguish the income from the cost-disease effect, proxied by aggregate productivity, since they are too highly correlated. Given the multicollinearity between productivity and income, the two effects were estimated separately. The estimated influence of each of the non-demographic drivers of LTC expenditures has been used to parameterise the projection equation in Box 5.

13 The relative price effect may be limited by a growing share of immigrants among LTC workers. According to Colombo et al., (2011), foreign-born workers play a significant and growing role in LTC in some countries. The average wage of the immigrant work force is lower than that of native workers and their bargaining power is weaker. The process of equalising the wages of foreign-born and native work forces will take time, but will certainly materialise over the long-run. 
Figure 3.4 Long-term care expenditure and GDP per capita

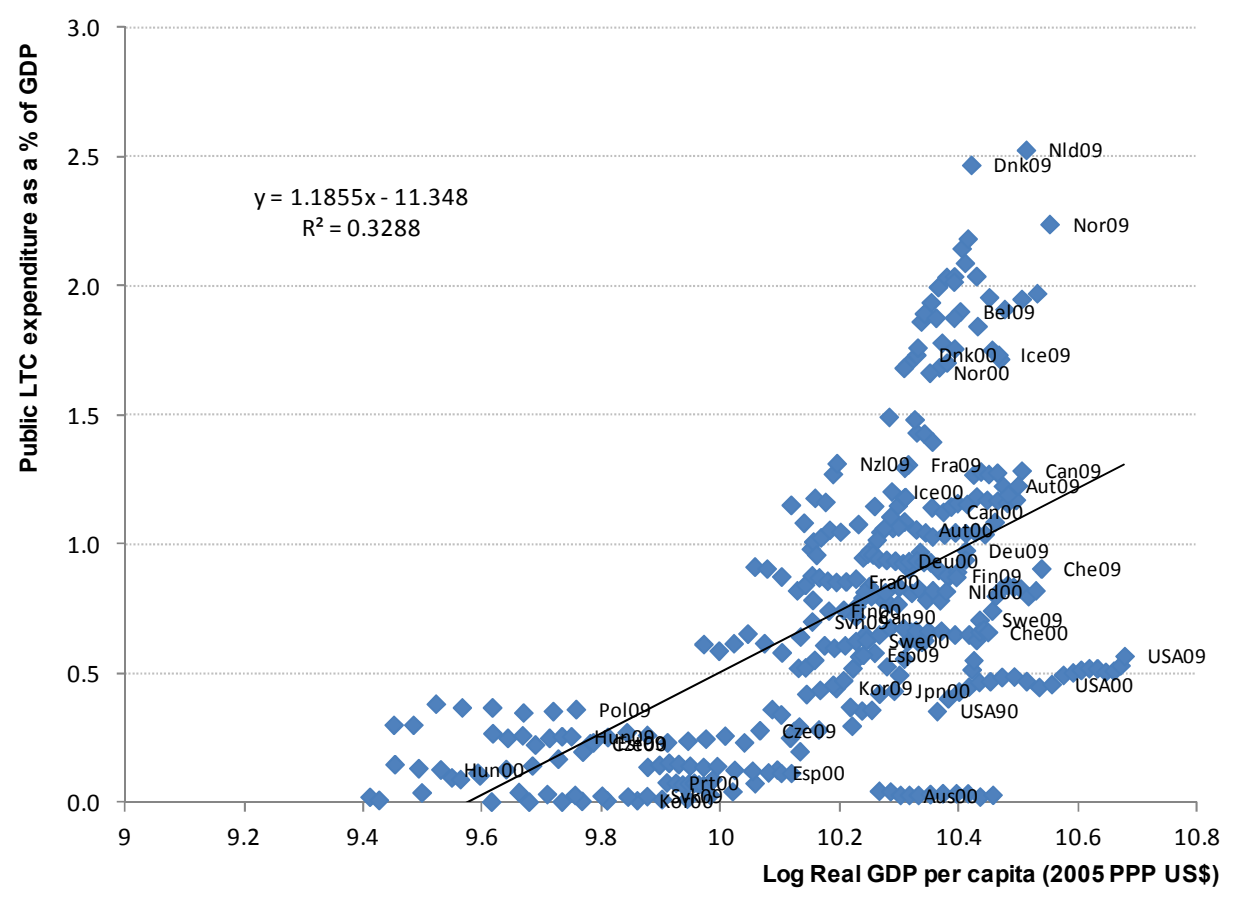

Source: OECD Health database

\section{Box 5. Estimations to calibrate the LTC framework}

In order to estimate the LTC spending elasticities to productivity (Baumol effect) and to the participation rate, which are used to parameterise the projections model, the following equation was estimated over the period 19902009.

$$
\log \left(\frac{L T C}{P_{Y} \cdot Y}\right)=\alpha+\beta * \log (\text { OAdep })+\gamma * \log (\text { Prod })+\delta * \log (P R)+u
$$

Where the share of long-term care expenditure in GDP $\left(\mathrm{LTC} /\left(\mathrm{P}_{\mathrm{y}}{ }^{*} \mathrm{Y}\right)\right)$ is explained by Prod, the total economy productivity capturing the Baumol effect (or alternatively the income per capita variable to estimate the income elasticity) and $P R$, the female labour force participation rate used as a proxy for the provision of informal care (or alternatively their exit rate from employment was also used). In this equation OAdep, the ratio of people aged 80 and above to total population, is a control variable that plays no role in the projections, as a demographic effect (Demo in equation 2) already covers the effects of ageing.

As expected, the old age dependency ratio (people above 80) is a significant determinant of LTC expenditure (Table A4.2 of Appendix 4). The relative price effect (proxied by total economy productivity) emerges with an elasticity of around two. Alternatively, when the income variable is introduced, its elasticity amounts to around 2.7. While regression estimates point to Baumol or Income elasticities higher than unity, a conservative choice has been made of a unitary elasticity for both the relative price and the income variable. Sensitivity analysis has been carried out to test for the impact of these assumptions with the income elasticity alternatively fixed at two (see below). Finally all the proxies for informal care (female participation or exit rate from the labour force) also turned out to be significant. 
ECO/WKP(2013)40

\subsection{Projection results: long-term care 2010-2060}

52. As for health care, a cost-pressure scenario and a cost-containment scenario were computed. Both scenarios are based on a unitary income elasticity assumption and the "healthy ageing" hypothesis. However, in the cost-pressure scenario, for OECD countries, a full Baumol effect is assumed, meaning that LTC unit labour costs increase fully in line with aggregate labour productivity; for non-OECD countries, excess labour supply especially in the non-tradeable sector suggests weaker wage pressures than in the OECD countries, and therefore the cost-pressure scenario only incorporates half of the Baumol effect. In the cost-containment scenario, the elasticity of LTC spending to productivity increases is set at half the value of the cost-pressure scenario ( 0.5 for OECD countries and 0.25 for non-OECD countries), possibly reflecting policy action aimed at mitigating relative wage increases of LTC providers. For example, action to curb expenditure could be aimed at facilitating access to LTC provision by low-skilled migrants or at providing incentives to balance institutional and home-based LTC.

53. Sensitivity analysis has been carried out in the context of the cost-containment scenario, with respect to the Baumol effect, the income elasticity and the implications of healthy ageing for the number of dependants. As for health care, the starting year of the projections is an average over the period 2006-2010 so as to smooth out the impact of the recent crisis. The main assumptions underlying each projection scenario are listed in Table 3.1.

Table 3.1. Assumptions underlying the alternative projection scenarios: public long-term care

\begin{tabular}{|c|c|c|c|c|}
\hline Scenarios & Health status & Income effect & Baumol effect & Availability of informal care \\
\hline Demographic effect & $\begin{array}{l}\text { Healthy ageing: the prevalence of dependency per age is } \\
\text { shifted according to the evolution of life expectancy and } \\
\text { health expenditure }\end{array}$ & n.a & n.a & n.a \\
\hline Cost-pressure scenario & $\begin{array}{l}\text { Healthy ageing: the prevalence of dependency per age is } \\
\text { shifted according to the evolution of life expectancy and } \\
\text { health expenditure (cost-containment scenario) }\end{array}$ & Income elasticity $=1$ & $\begin{array}{l}\text { OECD countries: Full Baumol effect } \\
\text { (elasticity }=1 \text { ) } \\
\text { BRIIICS: Half Baumol effect }\end{array}$ & $\begin{array}{l}\text { OECD countries: Baseline scenario for } \\
\text { participation rates of women aged } 50-64 \\
\text { BRIICS: total participation rates }\end{array}$ \\
\hline $\begin{array}{l}\text { Cost-containment } \\
\text { scenario }\end{array}$ & $\begin{array}{l}\text { Healthy ageing: the prevalence of dependency per age is } \\
\text { shifted according to the evolution of life expectancy and } \\
\text { health expenditure (cost-containment scenario) }\end{array}$ & Income elasticity $=1$ & $\begin{array}{l}\text { OECD countries: Half Baumol effect } \\
\text { (elasticity }=0.5 \text { ) } \\
\text { BRIICS : } 1 / 4 \text { of Baumol effect }\end{array}$ & $\begin{array}{l}\text { OECD countries: Baseline scenario for } \\
\text { participation rates of women aged } 50-64 \\
\text { BRIICS: total participation rates }\end{array}$ \\
\hline \multicolumn{5}{|c|}{ Sensitivity analysis based on the cost-containment scenario } \\
\hline Income elasticity $=2$ & $\begin{array}{l}\text { Healthy ageing: the prevalence of dependency per age is } \\
\text { shifted according to the evolution of life expectancy and } \\
\text { health expenditure }\end{array}$ & Income elasticity $=\mathbf{2}$ & $\begin{array}{l}\text { OECD countries: Half Baumol effect } \\
\text { (elasticity }=0.5 \text { ) } \\
\text { BRIICS : } 1 / 4 \text { of Baumol effect }\end{array}$ & $\begin{array}{l}\text { OECD countries: Baseline scenario for } \\
\text { participation rates of women aged } 50-64 \\
\text { BRIICS: total participation rates }\end{array}$ \\
\hline $\begin{array}{l}\text { Life expectancy plus } 2 \\
\text { standard deviation }\end{array}$ & $\begin{array}{l}\text { Healthy ageing: the prevalence of dependency per age is } \\
\text { shifted according to the evolution of life expectancy } \\
\text { plus } 2 \text { standard deviation and health expenditure }\end{array}$ & Income elasticity $=1$ & $\begin{array}{l}\text { OECD countries: Half Baumol effect } \\
\text { (elasticity }=0.5 \text { ) } \\
\text { BRIICS : } 1 / 4 \text { of Baumol effect }\end{array}$ & $\begin{array}{l}\text { OECD countries: Baseline scenario for } \\
\text { participation rates of women aged } 50-64 \\
\text { BRIICS: total participation rates }\end{array}$ \\
\hline $\begin{array}{l}\text { Life expectancy minus } \\
2 \text { standard deviation }\end{array}$ & $\begin{array}{l}\text { Healthy ageing: the prevalence of dependency per age is } \\
\text { shifted according to the evolution of life expectancy } \\
\text { minus } 2 \text { standard deviation and health expenditure }\end{array}$ & Income elasticity $=1$ & $\begin{array}{l}\text { OECD countries: Half Baumol effect } \\
\text { (elasticity }=0.5 \text { ) } \\
\text { BRIICS : } 1 / 4 \text { of Baumol effect }\end{array}$ & $\begin{array}{l}\text { OECD countries: Baseline scenario for } \\
\text { participation rates of women aged } 50-64 \\
\text { BRIICS: total participation rates }\end{array}$ \\
\hline $\begin{array}{l}\text { Cost-pressure health } \\
\text { scenario }\end{array}$ & $\begin{array}{l}\text { Healthy ageing: the prevalence of dependency per age is } \\
\text { shifted according to the evolution of life expectancy and } \\
\text { health expenditure cost pressure scenario }\end{array}$ & Income elasticity $=1$ & $\begin{array}{l}\text { OECD countries: Half Baumol effect } \\
\text { (elasticity }=0.5 \text { ) } \\
\text { BRIICS : } 1 / 4 \text { of Baumol effect }\end{array}$ & $\begin{array}{l}\text { OECD countries: Baseline scenario for } \\
\text { participation rates of women aged } 50-64 \\
\text { BRIICS: total participation rates }\end{array}$ \\
\hline
\end{tabular}

Note: The key assumption changed in each scenario is in bold.

54. As with projections of public health-care spending, non-demographic drivers account for the lion's share of future expenditure increases (Table 3.2), though with an assumed elasticity of unity, the income effect is not creating additional pressures in terms of expenditure shares to GDP. Demographic changes are projected to exert relatively minor influence on future public LTC expenditures. Indeed, as the LTC cost is independent of age, the pure age effect has only a moderate impact on spending. Moreover, this effect is mitigated by the 'healthy ageing' assumption. Detailed results for all scenarios are provided in Appendix 5. 
Table 3.2. Projection scenarios for public long-term care expenditure

\begin{tabular}{|c|c|c|c|c|c|c|c|}
\hline & \multirow[b]{2}{*}{$\begin{array}{c}\text { Average } \\
2006-2010\end{array}$} & \multicolumn{3}{|c|}{$\begin{array}{l}\text { Percentage point deviations from starting } \\
\text { period in } 2030\end{array}$} & \multicolumn{3}{|c|}{$\begin{array}{l}\text { Percentage point deviations from starting } \\
\text { period in } 2060\end{array}$} \\
\hline & & $\begin{array}{l}\text { Demographic } \\
\text { effect }\end{array}$ & Cost-pressure & $\begin{array}{l}\text { Cost- } \\
\text { containment }\end{array}$ & $\begin{array}{l}\text { Demographic } \\
\text { effect }\end{array}$ & $\begin{array}{l}\text { Cost- } \\
\text { pressure }\end{array}$ & $\begin{array}{l}\text { Cost- } \\
\text { containment }\end{array}$ \\
\hline Australia & 0.0 & 0.1 & 0.6 & 0.3 & 0.3 & 1.3 & 0.8 \\
\hline Austria & 1.1 & 0.1 & 0.5 & 0.3 & 0.2 & 1.0 & 0.7 \\
\hline Belgium & 1.7 & 0.1 & 0.5 & 0.3 & 0.1 & 1.2 & 0.7 \\
\hline Canada & 1.2 & 0.2 & 0.5 & 0.3 & 0.2 & 1.2 & 0.7 \\
\hline Chile & 0.0 & 0.2 & 0.9 & 0.6 & 0.6 & 2.3 & 1.5 \\
\hline Czech Republic & 0.3 & 0.2 & 0.7 & 0.3 & 0.4 & 1.6 & 0.9 \\
\hline Denmark & 2.2 & 0.1 & 0.4 & 0.2 & 0.2 & 1.0 & 0.6 \\
\hline Estonia & 0.2 & 0.1 & 0.7 & 0.3 & 0.3 & 2.0 & 0.9 \\
\hline Finland & 0.8 & 0.2 & 0.5 & 0.3 & 0.2 & 1.0 & 0.5 \\
\hline France & 1.1 & 0.1 & 0.5 & 0.2 & 0.2 & 1.0 & 0.6 \\
\hline Germany & 0.9 & 0.2 & 0.5 & 0.3 & 0.3 & 1.1 & 0.7 \\
\hline Greece & 0.5 & 0.1 & 0.6 & 0.4 & 0.3 & 1.4 & 0.9 \\
\hline Hungary & 0.3 & 0.1 & 0.6 & 0.3 & 0.3 & 1.8 & 1.0 \\
\hline Iceland & 1.7 & 0.2 & 0.3 & 0.1 & 0.2 & 1.0 & 0.5 \\
\hline Israel & 0.5 & 0.2 & 0.4 & 0.3 & 0.3 & 0.9 & 0.6 \\
\hline Ireland & 0.4 & 0.1 & 0.5 & 0.4 & 0.2 & 1.0 & 0.7 \\
\hline Italy & 0.7 & 0.1 & 0.5 & 0.3 & 0.2 & 1.2 & 0.8 \\
\hline Japan & 0.7 & 0.2 & 0.5 & 0.3 & 0.3 & 1.4 & 0.8 \\
\hline Korea & 0.3 & 0.4 & 0.8 & 0.5 & 0.8 & 2.0 & 1.3 \\
\hline Luxembourg & 0.9 & 0.1 & 0.5 & 0.4 & 0.3 & 0.8 & 0.7 \\
\hline Mexico & 0.0 & 0.2 & 0.7 & 0.5 & 0.6 & 2.2 & 1.5 \\
\hline Netherlands & 2.3 & 0.2 & 0.6 & 0.4 & 0.3 & 1.4 & 0.8 \\
\hline New Zealand & 1.3 & 0.2 & 0.5 & 0.3 & 0.3 & 1.4 & 0.8 \\
\hline Norway & 2.1 & 0.1 & 0.4 & 0.2 & 0.2 & 1.0 & 0.5 \\
\hline Poland & 0.4 & 0.2 & 0.7 & 0.3 & 0.5 & 1.8 & 1.0 \\
\hline Portugal & 0.1 & 0.1 & 0.4 & 0.2 & 0.3 & 1.3 & 0.8 \\
\hline Slovak Republic & 0.0 & 0.2 & 0.8 & 0.4 & 0.6 & 1.9 & 1.1 \\
\hline Slovenia & 0.7 & 0.2 & 0.6 & 0.4 & 0.4 & 1.5 & 0.9 \\
\hline Spain & 0.5 & 0.1 & 0.6 & 0.5 & 0.3 & 1.5 & 1.0 \\
\hline Sweden & 0.7 & 0.1 & 0.4 & 0.1 & 0.1 & 0.9 & 0.5 \\
\hline Switzerland & 1.2 & 0.1 & 0.5 & 0.3 & 0.3 & 1.3 & 0.7 \\
\hline Turkey & 0.0 & 0.2 & 0.7 & 0.3 & 0.6 & 2.3 & 1.6 \\
\hline United Kingdom & 0.9 & 0.1 & 0.3 & 0.2 & 0.1 & 0.9 & 0.5 \\
\hline United States & 0.6 & 0.1 & 0.4 & 0.2 & 0.2 & 0.8 & 0.4 \\
\hline$O E C D$ average ${ }^{1}$ & 0.8 & 0.1 & 0.5 & 0.3 & 0.3 & 1.4 & 0.8 \\
\hline Brazil & 0.0 & 0.2 & 0.3 & 0.3 & 0.7 & 1.2 & 0.9 \\
\hline China & 0.1 & 0.3 & 0.4 & 0.3 & 0.7 & 2.0 & 1.1 \\
\hline India & 0.1 & 0.1 & 0.3 & 0.2 & 0.4 & 1.5 & 0.8 \\
\hline Indonesia & 0.1 & 0.2 & 0.3 & 0.2 & 0.7 & 1.6 & 1.0 \\
\hline Russia & 0.2 & 0.1 & 0.2 & 0.1 & 0.2 & 0.8 & 0.4 \\
\hline South Africa & 0.2 & 0.1 & 0.2 & 0.2 & 0.3 & 0.7 & 0.5 \\
\hline 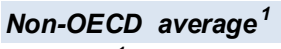 & 0.1 & 0.2 & 0.3 & 0.2 & 0.5 & 1.3 & 0.8 \\
\hline Average $^{1}$ & 0.7 & 0.2 & 0.5 & 0.3 & 0.3 & 1.4 & 0.8 \\
\hline
\end{tabular}

1. Unweighted average.

\subsubsection{The cost-pressure scenario}

55. In the cost-pressure scenario, starting from $0.8 \%$ of GDP on average for OECD countries, the ratio of public LTC expenditure to GDP is projected to increase by 1.4 percentage points to reach $2.1 \%$ of GDP. However, some countries, like Chile, Estonia, Korea, Mexico and Turkey, will experience higher increases (equal to or above 2 percentage points). These countries are starting from a very low level of 
LTC expenditure and are in the process of catching up to higher levels. Conversely, Israel, Luxembourg, Sweden, the United-Kingdom and the United States are projected to experience only small increases in their LTC expenditure to GDP ratios (less than 1 percentage point). Differences in the initial level of female participation rates as well as policies in place also explain the differences across countries. For nonOECD countries, the increase in LTC spending is projected to be, on average, broadly the same as that experienced by OECD countries but starting from a much lower level $(0.1 \%)$. For OECD countries, the average annual increase of public LTC expenditure will be about the same before and after $2030 \Leftrightarrow 0.03$ percentage points) whereas it will be slightly more important after $2030(\approx 0.03$ percentage points $)$ than before $(\approx 0.01$ percentage points $)$ for non-OECD countries.

\subsubsection{The cost-containment scenario}

56. In the cost-containment scenario, on average for OECD countries, the public LTC expenditure to GDP ratio increases by 0.8 percentage point from $0.8 \%$ to $1.6 \%$ of GDP. Chile, Korea, Mexico and Turkey experience the most important increases (above 1.3 percentage points), while the increase in Finland, Iceland, Norway, Sweden, the United Kingdom and the United States does not exceed 0.5 percentage points. Non-OECD countries will experience on average the same increase as OECD countries ( 0.8 percentage points). Again for OECD countries, the average annual increase of public LTC expenditure will be about the same before and after $2030(\approx 0.02$ percentage points $)$ whereas it will be slightly more important after $2030(\approx 0.02$ percentage points $)$ than before $(\approx 0.01$ percentage points $)$ for non-OECD countries.

\subsection{Sensitivity analysis}

57. Given the uncertainty about income effects, projections were performed also assuming an income elasticity of two for the cost-containment scenario for OECD countries. For non-OECD countries, the sensitivity analysis assumed an income elasticity of 1.5. On average, for OECD countries LTC expenditure would reach in this case $2.5 \%$ of GDP in 2060. In this scenario, Chile, Estonia, Mexico and Turkey would experience a deviation from base case of around 1.7 percentage points of GDP. Again, the assumptions underlying the GDP projections assume some catch-up for these low income countries, explaining why their LTC expenditure patterns are more affected by the higher income elasticity assumption. For nonOECD countries, the share of LTC in GDP would reach $1.8 \%$ of GDP with the higher income elasticity. China, India and Indonesia would experience a deviation from base case of more than 1 percentage point (see Table 3.3).

58. A sensitivity analysis has also been carried out for the evolution of the number of dependants. The two drivers of the dependency ratio, life expectancy and health care spending, have been changed separately relative to baseline. Taking life expectancy plus (minus) two standard deviations would induce an average deviation from base case for OECD countries of $0.3(-0.2)$ percentage points in the LTC expenditure to GDP ratio, which would then reach, on average, 1.9\% (1.4\%) of GDP. For each scenario, the expenditure for non-OECD countries will deviate from base case by the same amount as for OECD countries. Due to the very limited impact of health expenditure, alternative assumptions in this area have only a slight impact. Indeed, even under the cost-pressure health care spending scenario, the LTC expenditure to GDP ratio would only deviate from the base case by 0.1 percentage points on average for both OECD and non-OECD countries. 
Table 3.3. Sensitivity analysis on public long-term care projections

(Performed on the cost-containment scenario)

\begin{tabular}{|c|c|c|c|c|}
\hline & $\begin{array}{c}\text { Income } \\
\text { elasticity= } 2^{1}\end{array}$ & $\begin{array}{c}\text { Life expectancy } \\
\text { plus } 2 \text { standard } \\
\text { deviation }\end{array}$ & $\begin{array}{l}\text { Life expectancy } \\
\text { minus } 2 \text { standard } \\
\text { deviation }\end{array}$ & $\begin{array}{c}\text { Cost-pressure } \\
\text { health-care } \\
\text { expenditure }\end{array}$ \\
\hline & \multicolumn{4}{|c|}{ Percentage point deviations from cost-containment scenario in 2060} \\
\hline Australia & 1.0 & 0.2 & -0.2 & 0.1 \\
\hline Austria & 0.6 & 0.2 & -0.2 & 0.1 \\
\hline Belgium & 0.8 & 0.2 & -0.2 & 0.1 \\
\hline Canada & 0.8 & 0.2 & -0.2 & 0.1 \\
\hline Chile & 1.7 & 0.3 & -0.2 & 0.1 \\
\hline Czech Republic & 1.3 & 0.3 & -0.2 & 0.1 \\
\hline Denmark & 0.8 & 0.2 & -0.2 & 0.1 \\
\hline Estonia & 1.8 & 0.3 & -0.2 & 0.1 \\
\hline Finland & 0.8 & 0.2 & -0.2 & 0.1 \\
\hline France & 0.6 & 0.2 & -0.2 & 0.1 \\
\hline Germany & 0.8 & 0.3 & -0.2 & 0.1 \\
\hline Greece & 0.6 & 0.3 & -0.2 & 0.1 \\
\hline Hungary & 1.4 & 0.3 & -0.2 & 0.1 \\
\hline Iceland & 0.8 & 0.2 & -0.2 & 0.1 \\
\hline Israel & 0.7 & 0.2 & -0.2 & 0.1 \\
\hline Ireland & 0.5 & 0.2 & -0.2 & 0.1 \\
\hline Italy & 0.6 & 0.2 & -0.2 & 0.1 \\
\hline Japan & 0.9 & 0.3 & -0.2 & 0.1 \\
\hline Korea & 1.0 & 0.4 & -0.3 & 0.2 \\
\hline Luxembourg & 0.1 & 0.3 & -0.2 & 0.1 \\
\hline Mexico & 1.7 & 0.3 & -0.3 & 0.1 \\
\hline Netherlands & 0.8 & 0.3 & -0.2 & 0.1 \\
\hline New Zealand & 1.2 & 0.2 & -0.2 & 0.1 \\
\hline Norway & 0.8 & 0.2 & -0.2 & 0.1 \\
\hline Poland & 1.1 & 0.3 & -0.2 & 0.1 \\
\hline Portugal & 0.7 & 0.3 & -0.2 & 0.1 \\
\hline Slovak Republic & 1.3 & 0.3 & -0.3 & 0.1 \\
\hline Slovenia & 0.9 & 0.3 & -0.2 & 0.1 \\
\hline Spain & 0.7 & 0.3 & -0.2 & 0.1 \\
\hline Sweden & 0.9 & 0.2 & -0.2 & 0.1 \\
\hline Switzerland & 0.9 & 0.3 & -0.2 & 0.1 \\
\hline Turkey & 1.7 & 0.3 & -0.2 & 0.1 \\
\hline United Kingdom & 0.8 & 0.2 & -0.2 & 0.1 \\
\hline United States & 0.7 & 0.2 & -0.2 & 0.1 \\
\hline$O E C D$ average $^{2}$ & 0.9 & 0.3 & -0.2 & 0.1 \\
\hline Brazil & 0.6 & 0.4 & -0.3 & 0.1 \\
\hline China & 1.2 & 0.4 & -0.3 & 0.1 \\
\hline India & 1.3 & 0.2 & -0.2 & 0.1 \\
\hline Indonesia & 1.0 & 0.3 & -0.3 & 0.1 \\
\hline Russia & 0.5 & 0.2 & -0.2 & 0.1 \\
\hline South Africa & 0.7 & 0.2 & -0.1 & 0.1 \\
\hline Non-OECD average $^{2}$ & 0.9 & 0.3 & -0.2 & 0.1 \\
\hline Average $^{2}$ & 0.9 & 0.3 & -0.2 & 0.1 \\
\hline
\end{tabular}




\section{Prospects for total public spending on health and comparison with other projections}

\subsection{Overall and cross-country projection results}

59. Both health and LTC expenditures are projected to put sizeable pressure on public finance over the next 50 years. Overall, on average across OECD countries, the total health and LTC expenditure to GDP ratio is projected to more than double in the cost-pressure scenario, increasing from $6.2 \%$ in the starting period to $13.9 \%$ of GDP in 2060 . In the cost-containment scenario the ratio would still increase by more than half, to reach 9.5\% (Figure 4.1). For the BRIICS, starting from a much lower level, public health and LTC expenditure will increase from $2.5 \%$ in the starting period to about $10 \%$ and above $5 \%$ in 2060 in the cost-pressure and the cost-containment scenario respectively.

Figure 4.1. Projected public health and LTC expenditure

(As a \% of GDP, in 2060)

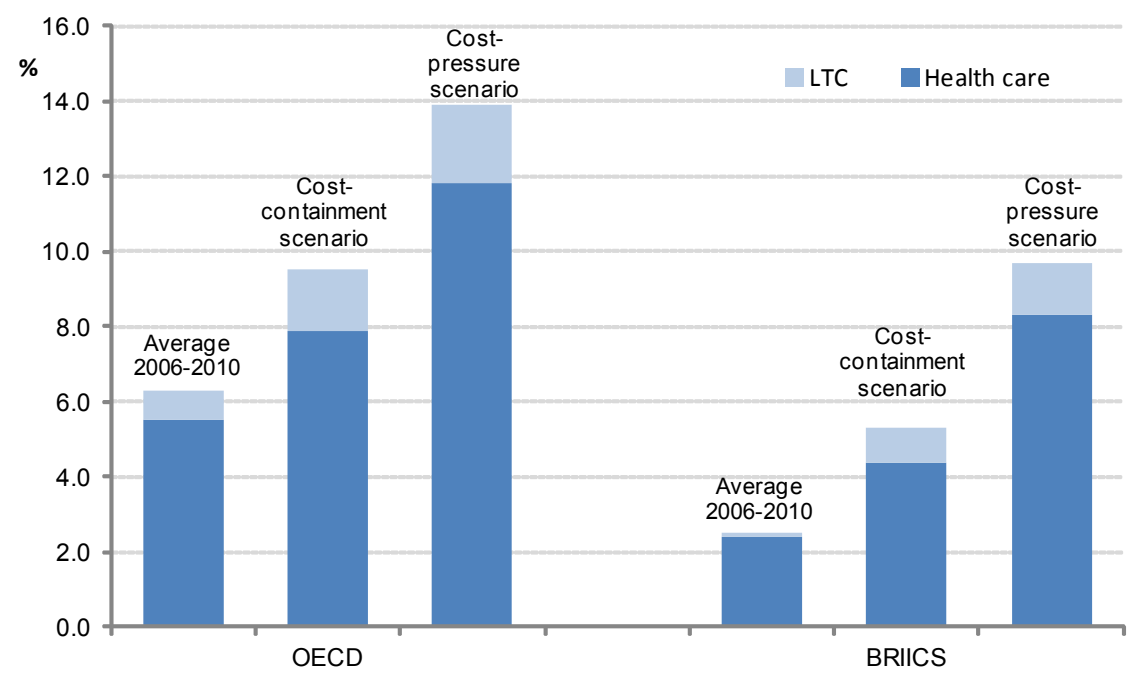

60. There are, however, striking differences across countries (Figure 4.2). In the cost-containment scenario, one group of countries experiences a 4 to 5 percentage point increase in total spending to GDP ratios over the period 2010-2060. It includes countries that are ageing very rapidly (Korea and Chile), as well as those with currently low labour participation, which may face a substantial increase in the demand for formal long-term care (Spain and Mexico). By contrast, in the United States, the United Kingdom and the Nordic countries the projected increase is below 3 percentage points of GDP. In these countries demographic trends will be more stable. On average, non-OECD countries will experience a lower percentage point increase than OECD countries. Nonetheless, the lower initial spending to GDP ratios of these countries will more than double by 2060 (Table 4.1). 
Figure 4.2 Percentage point increase in the total public health and long-term care spending ratio to GDP, 20102060

\section{Range of estimates across sensitivity analyses ${ }^{1}$}

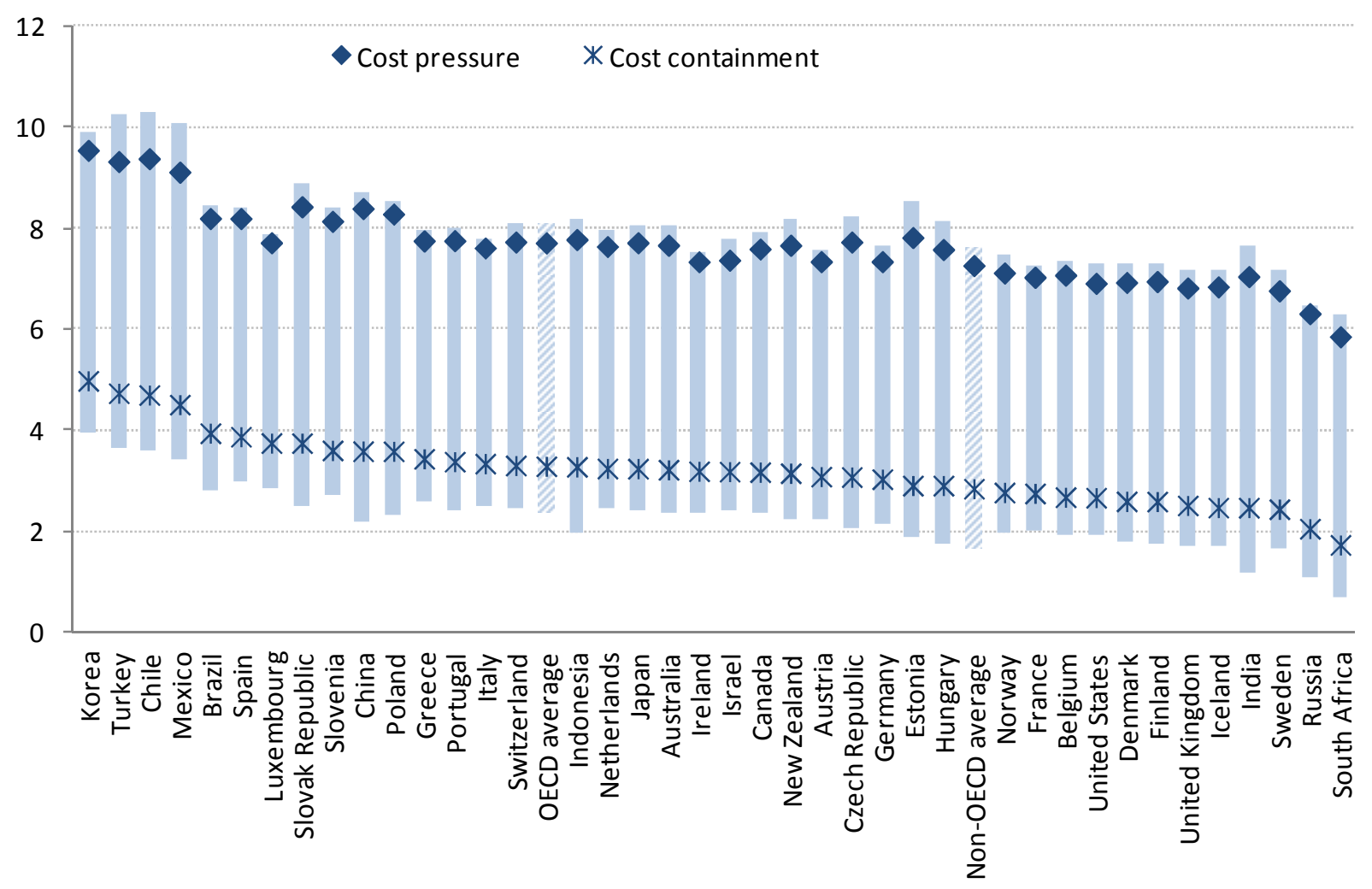

1. The vertical bars correspond to the range of the alternative scenarios, including sensitivity analysis. Countries are ranked by the increase of expenditures between 2010 and 2060 in the cost-containment scenario. 
Table 4.1. Projection scenarios for public health and long-term care spending

In \% of GDP

\begin{tabular}{|c|c|c|c|c|c|c|c|c|c|}
\hline & \multicolumn{3}{|c|}{ Health care } & \multicolumn{3}{|c|}{ Long-term care } & \multicolumn{3}{|c|}{ Total } \\
\hline & \multirow{2}{*}{$\begin{array}{l}\text { Average } \\
2006-2010\end{array}$} & \multicolumn{2}{|c|}{2060} & \multirow{2}{*}{$\begin{array}{c}\text { Average } \\
2006-2010 \\
\end{array}$} & \multicolumn{2}{|c|}{2060} & \multirow{2}{*}{$\begin{array}{c}\text { Average } \\
2006-2010\end{array}$} & \multicolumn{2}{|r|}{2060} \\
\hline & & $\begin{array}{c}\text { Cost- } \\
\text { pressure }\end{array}$ & $\begin{array}{c}\text { Cost- } \\
\text { containment } \\
\end{array}$ & & $\begin{array}{c}\text { Cost- } \\
\text { pressure }\end{array}$ & $\begin{array}{c}\text { Cost- } \\
\text { containment } \\
\end{array}$ & & $\begin{array}{c}\text { Cost- } \\
\text { pressure }\end{array}$ & $\begin{array}{c}\text { Cost- } \\
\text { containment }\end{array}$ \\
\hline Australia & 5.6 & 12.0 & 8.1 & 0.0 & 1.4 & 0.8 & 5.7 & 13.3 & 8.9 \\
\hline Austria & 6.6 & 12.9 & 9.1 & 1.1 & 2.2 & 1.8 & 7.8 & 15.1 & 10.8 \\
\hline Belgium & 5.8 & 11.6 & 7.7 & 1.7 & 3.0 & 2.5 & 7.5 & 14.6 & 10.2 \\
\hline Canada & 5.8 & 12.2 & 8.3 & 1.2 & 2.5 & 1.9 & 7.1 & 14.6 & 10.2 \\
\hline Chile & 3.1 & 10.2 & 6.3 & 0.0 & 2.3 & 1.5 & 3.1 & 12.4 & 7.8 \\
\hline Czech Republic & 5.5 & 11.6 & 7.7 & 0.3 & 1.9 & 1.1 & 5.8 & 13.5 & 8.9 \\
\hline Denmark & 6.3 & 12.2 & 8.3 & 2.2 & 3.3 & 2.8 & 8.5 & 15.4 & 11.1 \\
\hline Estonia & 4.3 & 10.1 & 6.2 & 0.2 & 2.2 & 1.1 & 4.5 & 12.3 & 7.4 \\
\hline Finland & 5.2 & 11.2 & 7.3 & 0.8 & 1.8 & 1.3 & 6.0 & 13.0 & 8.6 \\
\hline France & 7.4 & 13.5 & 9.6 & 1.1 & 2.1 & 1.7 & 8.5 & 15.5 & 11.3 \\
\hline Germany & 7.3 & 13.5 & 9.6 & 0.9 & 2.1 & 1.6 & 8.2 & 15.5 & 11.2 \\
\hline Greece & 5.4 & 11.8 & 7.9 & 0.5 & 1.9 & 1.5 & 5.9 & 13.7 & 9.3 \\
\hline Hungary & 4.8 & 10.6 & 6.7 & 0.3 & 2.0 & 1.2 & 5.0 & 12.6 & 7.9 \\
\hline Iceland & 5.8 & 11.7 & 7.8 & 1.7 & 2.7 & 2.2 & 7.6 & 14.4 & 10.0 \\
\hline Israel & 4.0 & 10.4 & 6.6 & 0.5 & 1.5 & 1.2 & 4.5 & 11.9 & 7.7 \\
\hline Ireland & 5.5 & 11.9 & 8.0 & 0.4 & 1.3 & 1.1 & 5.9 & 13.3 & 9.1 \\
\hline Italy & 6.1 & 12.6 & 8.7 & 0.7 & 1.9 & 1.5 & 6.9 & 14.5 & 10.2 \\
\hline Japan & 6.1 & 12.5 & 8.6 & 0.7 & 2.0 & 1.4 & 6.8 & 14.5 & 10.0 \\
\hline Korea & 3.3 & 10.9 & 7.0 & 0.3 & 2.3 & 1.6 & 3.6 & 13.2 & 8.6 \\
\hline Luxembourg & 4.4 & 11.3 & 7.4 & 0.9 & 1.7 & 1.7 & 5.3 & 13.0 & 9.1 \\
\hline Mexico & 2.5 & 9.4 & 5.5 & 0.0 & 2.2 & 1.5 & 2.5 & 11.6 & 7.0 \\
\hline Netherlands & 6.4 & 12.7 & 8.8 & 2.3 & 3.7 & 3.1 & 8.7 & 16.4 & 12.0 \\
\hline New Zealand & 6.4 & 12.7 & 8.8 & 1.3 & 2.6 & 2.0 & 7.7 & 15.3 & 10.8 \\
\hline Norway & 5.1 & 11.2 & 7.3 & 2.1 & 3.1 & 2.7 & 7.2 & 14.3 & 10.0 \\
\hline Poland & 4.1 & 10.5 & 6.7 & 0.4 & 2.2 & 1.4 & 4.5 & 12.7 & 8.0 \\
\hline Portugal & 6.5 & 13.0 & 9.1 & 0.1 & 1.4 & 0.9 & 6.6 & 14.3 & 9.9 \\
\hline Slovak Republic & 5.4 & 11.9 & 8.0 & 0.0 & 1.9 & 1.1 & 5.4 & 13.9 & 9.2 \\
\hline Slovenia & 5.2 & 11.8 & 7.9 & 0.7 & 2.2 & 1.5 & 5.8 & 14.0 & 9.4 \\
\hline Spain & 5.6 & 12.3 & 8.5 & 0.5 & 2.0 & 1.6 & 6.1 & 14.3 & 10.0 \\
\hline Sweden & 6.6 & 12.4 & 8.6 & 0.7 & 1.6 & 1.1 & 7.2 & 14.0 & 9.7 \\
\hline Switzerland & 5.7 & 12.2 & 8.3 & 1.2 & 2.5 & 1.9 & 6.9 & 14.6 & 10.2 \\
\hline Turkey & 3.8 & 10.9 & 7.0 & 0.0 & 2.3 & 1.6 & 3.8 & 13.2 & 8.6 \\
\hline United Kingdom & 6.5 & 12.4 & 8.5 & 0.9 & 1.8 & 1.4 & 7.4 & 14.2 & 9.9 \\
\hline United States & 7.1 & 13.2 & 9.3 & 0.6 & 1.3 & 1.0 & 7.6 & 14.5 & 10.3 \\
\hline$O E C D$ average ${ }^{1}$ & 5.5 & 11.8 & 7.9 & 0.8 & 2.1 & 1.6 & 6.2 & 13.9 & 9.5 \\
\hline Brazil & 3.7 & 10.7 & 6.8 & 0.0 & 1.3 & 0.9 & 3.7 & 11.9 & 7.7 \\
\hline China & 1.9 & 8.3 & 4.4 & 0.1 & 2.1 & 1.2 & 2.0 & 10.4 & 5.6 \\
\hline India & 1.2 & 6.7 & 2.8 & 0.1 & 1.6 & 0.9 & 1.3 & 8.3 & 3.7 \\
\hline Indonesia & 1.2 & 7.3 & 3.5 & 0.1 & 1.7 & 1.0 & 1.2 & 9.0 & 4.5 \\
\hline Russia & 3.1 & 8.6 & 4.7 & 0.2 & 1.0 & 0.7 & 3.4 & 9.7 & 5.4 \\
\hline South Africa & 3.2 & 8.4 & 4.5 & 0.2 & 0.9 & 0.6 & 3.4 & 9.2 & 5.1 \\
\hline Non-OECD average ${ }^{1}$ & 2.4 & 8.3 & 4.4 & 0.1 & 1.4 & 0.9 & 2.5 & 9.8 & 5.3 \\
\hline Total average ${ }^{1}$ & 5.0 & 11.3 & 7.4 & 0.7 & 2.0 & 1.5 & 5.7 & 13.3 & 8.9 \\
\hline
\end{tabular}

1. Unweighted average.

Source: Authors' calculations. 


\subsection{Comparison with previous and other projections}

61. These new projections broadly deliver the same message as those in Oliveira Martins and de la Maisonneuve (2006); even in the cost-containment scenario public health care and LTC spending will put an important burden on future public finances (Table 4.2). The new set of projections suggests a more important increase in health care expenditure, both in the cost-pressure and the cost-containment scenarios. This may be explained by the assumption of a stronger non-demographic, non-income effect, reflecting a better understanding of the evolution of the underlying determinants of the unexplained residual and a lower assumption on the income elasticity. Conversely, regarding public LTC funding, the increase in expenditure is lower in the new set of projections than in the previous one. This may be explained by the fact that LTC costs in the current exercise are more appropriately treated as being independent of age and, as a result, appear mainly driven by non-demographic factors. Regarding the latter, the labour productivity assumptions underlying the new projections are lower than the previous ones and as a result the Baumol effect is weaker in the new projections. Finally the starting point is based on more reliable data displaying a lower value for several countries. Overall, on average, the current projections suggest a slightly lower increase in total health and LTC expenditure confirming the message delivering by the previous set of projections.

Table 4.2. Public health and long-term care spending: comparison with previous projections ${ }^{1}$

Differences in \% points of GDP between the current and the previous projections in 2050

\begin{tabular}{|c|c|c|c|c|c|c|}
\hline & \multicolumn{2}{|c|}{ Health care } & \multicolumn{2}{|c|}{ Long-term care } & \multicolumn{2}{|c|}{ Total } \\
\hline & Cost-pressure & Cost-containment & Cost-pressure & Cost-containment & Cost-pressure & Cost-containment \\
\hline Austria & 3.9 & 3.5 & -1.3 & -0.8 & 2.7 & 2.7 \\
\hline Finland & 2.6 & 2.2 & -3.5 & -2.9 & -0.9 & -0.8 \\
\hline Sweden & 2.3 & 1.9 & -2.9 & -2.4 & -0.6 & -0.5 \\
\hline Netherlands & 2.3 & 1.9 & -0.2 & 0.1 & 2.2 & 2.0 \\
\hline United States & 1.9 & 1.5 & -1.4 & -0.9 & 0.5 & 0.6 \\
\hline Denmark & 1.9 & 1.5 & -1.1 & -0.6 & 0.8 & 0.9 \\
\hline Greece & 1.4 & 1.0 & -1.1 & -0.6 & 0.3 & 0.3 \\
\hline Korea & 1.4 & 1.0 & -2.0 & -1.7 & -0.6 & -0.7 \\
\hline France & 1.4 & 0.9 & -0.8 & -0.4 & 0.5 & 0.5 \\
\hline Italy & 1.3 & 0.8 & -1.8 & -1.4 & -0.5 & -0.6 \\
\hline United Kingdom & 1.2 & 0.7 & -1.4 & -0.8 & -0.2 & -0.1 \\
\hline Belgium & 1.1 & 0.7 & -0.7 & -0.3 & 0.5 & 0.4 \\
\hline Spain & 1.1 & 0.6 & -0.8 & -0.4 & 0.3 & 0.2 \\
\hline New Zealand & 1.0 & 0.6 & -0.1 & 0.2 & 1.0 & 0.8 \\
\hline Switzerland & 1.0 & 0.6 & -0.4 & -0.1 & 0.6 & 0.4 \\
\hline Germany & 0.7 & 0.3 & -1.0 & -0.7 & -0.3 & -0.4 \\
\hline Australia & 0.6 & 0.1 & -1.7 & -1.3 & -1.1 & -1.2 \\
\hline Japan & 0.6 & 0.1 & -1.3 & -1.1 & -0.7 & -1.0 \\
\hline Slovak Republic & 0.5 & 0.1 & -1.1 & -0.7 & -0.5 & -0.6 \\
\hline Canada & 0.4 & 0.0 & -1.0 & -0.6 & -0.5 & -0.6 \\
\hline Portugal & 0.4 & -0.1 & -1.1 & -0.6 & -0.7 & -0.6 \\
\hline Ireland & 0.3 & -0.1 & -3.2 & -2.1 & -2.9 & -2.2 \\
\hline Poland & 0.2 & -0.2 & -1.9 & -0.6 & -1.6 & -0.9 \\
\hline Mexico & 0.1 & -0.3 & -2.5 & -1.9 & -2.4 & -2.2 \\
\hline Luxembourg & -0.2 & -0.7 & -2.1 & -0.9 & -2.4 & -1.6 \\
\hline Iceland & -0.5 & -0.9 & -1.9 & -1.3 & -2.4 & -2.2 \\
\hline Turkey & -1.0 & -1.4 & 0.1 & 0.4 & -0.9 & -1.0 \\
\hline Norway & -1.1 & -1.5 & -1.3 & -1.0 & -2.4 & -2.5 \\
\hline Czech Republic & -1.2 & -1.7 & -0.5 & -0.5 & -1.7 & -2.1 \\
\hline Hungary & -1.4 & -1.9 & -0.7 & 0.0 & -2.1 & -1.9 \\
\hline$O E C D$ average $^{2}$ & 0.8 & 0.4 & -1.4 & -0.9 & -0.5 & -0.5 \\
\hline
\end{tabular}

1. Countries are ranked relative to the differences in the health-care cost-containment scenario.

2. Unweighted average.

Source: Oliveira Martins and de la Maisonneuve (2006) and authors' calculations. 
62. A comparison between this paper, the European Commission, the IMF and the Congressional Budget Office in the United States for selected countries is provided in Table 4.3. Differences reflect mainly varying assumptions concerning the future evolution of the main drivers of spending:

- Regarding the demographic drivers, all projections assume healthy ageing, although not at the same pace. While the OECD projections assume that one year gain in life expectancy is translated into one year in good health, the European Commission and the IMF are more conservative and assume that one year gain in life expectancy is translated into one half year in good health.

- As regards non-demographic drivers the OECD, the IMF and the CBO disentangle the income effect from the other effects while, in its reference scenario the EC bundles all non-demographic effects together, assuming implicitly no residual growth. The OECD income elasticity is set to 0.8 while the IMF's and the CBO's ones are 0.3 and 1 respectively. The OECD residual growth is common for all countries and decreases from 1.7 to 0 in the cost-containment scenario while it is kept constant over the whole period in the cost-pressure scenario. The IMF residual is countryspecific and is kept constant over the projection period, while the CBO projections for the United States assume a non-demographic growth above income of $1.6 \%$ for both Medicare and Medicaid in 2010 decreasing to $1 \%$ for Medicare and to 0 for Medicaid in 2087. The EC assumes an income elasticity of 1.1 in 2010 decreasing to 1 in 2060.

63. As a consequence of these different assumptions, the EC projected increases in health-care expenditure are the lowest due to the nearly unitary income elasticity associated with the absence of a residual growth. The IMF projections, although difficult to compare as they end in 2050, seem to range between the OECD cost-containment and cost-pressure scenarios. The assumption of low income elasticity is broadly offset by the country specific residual. Nonetheless when the estimated residual is higher than the average like in the United States, the projected increase in health care expenditure is much higher. This high increase is corroborated by the $\mathrm{CBO}$ projections.

Table 4.3. Public spending on health care: a comparison of different projections

\begin{tabular}{|c|c|c|c|c|c|}
\hline & $\begin{array}{c}\text { OECD } \\
\text { (Cost-containment scenario) }\end{array}$ & $\begin{array}{c}\text { OECD } \\
\text { (Cost-pressure scenario) }\end{array}$ & $\begin{array}{c}\text { EC - AWG } \\
\text { (Reference scenario) }\end{array}$ & IMF & $\begin{array}{c}\text { CBO } \\
\text { (Extended Baseline Scenario) }\end{array}$ \\
\hline Methodology & \multicolumn{2}{|c|}{ Accounting framework } & & $\begin{array}{c}\text { Econometric model } \\
\text { (Regression in first } \\
\text { differences) }\end{array}$ & \\
\hline Healthy ageing & $\begin{array}{c}1 \text { year gain in } L E=1 \text { year in } \\
\text { good health }\end{array}$ & $\begin{array}{c}1 \text { year gain in LE }=1 \text { year in } \\
\text { good health }\end{array}$ & $\begin{array}{c}1 \text { year gain in } L E=1 / 2 \\
\text { year in good health }\end{array}$ & $\begin{array}{c}1 \text { year gain in } L E=1 / 2 \text { year in } \\
\text { good health }\end{array}$ & Yes \\
\hline Income elasticity & 0.8 & 0.8 & $\begin{array}{c}1.1 \text { in } 2010==>1 \text { in } 2060 \\
\text { (Includes other non- } \\
\text { demographic factors) }\end{array}$ & 0.3 & 1 \\
\hline Residual growth & $\begin{array}{c}\text { Common residual } \\
1.7 \% \text { in } 2010==>0 \% \text { in } 2060\end{array}$ & \begin{tabular}{|} 
Common residual \\
$1.7 \%$ kept constant over the \\
projection period
\end{tabular} & .. & $\begin{array}{l}\text { Country specific residual kept } \\
\text { constant over the projection } \\
\text { period }\end{array}$ & $\begin{array}{c}\text { Medicare: } 1.6 \%==>\text { less than } 1.5 \% \text { in } \\
2030==>1.0 \% \text { in } 2087 \\
\text { Medicaid: } 1.6 \%==>1.3 \% \text { in } \\
2023==>0 \% \text { in } 2087\end{array}$ \\
\hline $\begin{array}{l}\text { Results } \\
\text { (Selected OECD countries) }\end{array}$ & \multicolumn{3}{|c|}{ In 2060 \% pp difference from 2010} & $\begin{array}{c}\text { In } 2050 \% \text { pp difference from } \\
2010\end{array}$ & In $2060 \%$ pp difference from 2010 \\
\hline France & 2.2 & 6.1 & 1.4 & 2.6 & .. \\
\hline Germany & 2.3 & 6.2 & 1.4 & 1.5 & .. \\
\hline Italy & 2.6 & 6.4 & 0.6 & 1.1 & .. \\
\hline Netherlands & 2.4 & 6.3 & 1.0 & 4.9 & .. \\
\hline Spain & 2.8 & 6.7 & 1.3 & 3.5 &.. \\
\hline United Kingdom & 2.0 & 5.9 & 1.1 & 8.2 & .. \\
\hline EU15 & 2.4 & 6.2 & 1.1 & 4.5 & $\ddot{\pi}$ \\
\hline USA & 2.2 & 6.1 &.. & 11.3 & 7.3 \\
\hline
\end{tabular}

Source: OECD, IMF, "The Economics of Public Health Care Reform in Advanced and Emerging Economies", European Commission, "The 2012 Ageing Report" and Congressional Budget Office, "The 2012 Long-term Budget Outlook". 


\section{Concluding remarks}

64. Long-term spending projections are inherently uncertain and subject to upside or downside risks. While a more moderate evolution of spending than in these projections cannot be excluded (for instance if cost-saving technologies were to spread out, or if more aggressive cost-containment policies were to be implemented), these are also clear upside risks on spending. For instance, higher health spending could arise due to an extension of the pre-death period of ill health as longevity increases or because of higher than expected costs induced by technical progress. Regarding LTC, higher spending could arise from increased dependency due to obesity trends or dementia. Indeed, according to recent calculations, some $12 \%$ of those aged between 80 and 84 years, and almost one in four of those aged over 85 years, suffer from dementia (Alzheimer Europe, 2006). With ageing populations, strong increases in the prevalence of dementia may be expected (see Box 1.1 in Colombo et al., (2011)), though prevention and treatment may also improve in the future.

65. Even if these upside risks do not materialise, the spending projections point to important policy challenges. These challenges are reinforced by the evidence that macroeconomic cost-containment policies, which had some success in repressing spending trends over the 1980s and 1990s, have their limits. For instance, it is difficult to contain wages and at the same time, attract young and skilled workers into the health-care system. Similarly, controlling prices is not easy when technical progress is permanently creating new products and treatments, while overall constraints on supply result in unpopular waiting lists for these treatments. More generally, it is difficult to determine the appropriate supply of health and LTC services without market signals - but at the same time, health and LTC are areas where market failure is rife. 
ECO/WKP(2013)40

\section{APPENDIX 1. DATA SOURCES AND METHOD}

\section{Health and LTC data}

\section{Health and LTC expenditures}

66. The historical public current health and LTC expenditure to GDP ratios come from the OECD Health Database (2011) that provides comparable health statistics across OECD countries. Total public current expenditure on health is the sum of total personal and total collective services but excludes investment. The LTC spending corresponds to the "Services of long-term nursing care" item. The latter is subtracted from the Total public current expenditure to get the health spending.

67. Total expenditure on health is defined as the sum of expenditure on activities that - through application of medical, paramedical, and nursing knowledge and technology - are aimed at: promoting health and preventing disease; curing illness and reducing premature mortality; caring for persons affected by chronic illness who require nursing care; caring for persons with health-related impairments, disability, and handicaps who require nursing care; assisting patients to die with dignity; providing and administering public health; providing and administering health programmes, health insurance and other funding arrangements. Public expenditure on health care is health expenditure incurred by public funds. Public funds are state, regional and local Government bodies and social security schemes.

68. Long-term health care comprises ongoing health and nursing care given to in-patients who need assistance on a continuing basis due to chronic impairments and a reduced degree of independence in activities of daily living. In-patient long-term care is provided in institutions or community facilities. Longterm care is typically a mix of medical (including nursing care) and social services.

\section{Cost curves by age groups}

69. The public health expenditure by age groups have been provided by the European Commission for the European countries (2009 Ageing report) and by the Swiss Federal Statistical Office, Health Canada and the Australian Institute for Health and Welfare for Switzerland, Canada and Australia respectively. These cost curves are split into survivors and non-survivors as explained in the text.

70. An average expenditure curve for survivors was estimated econometrically in a panel of 23 countries and 20 age groups, using a spline function as follows:

$$
\frac{h_{\text {age group }}}{N_{\text {age group }}}=-199.1 . \text { age }+14.5 . \text { age }^{2}-0.41 . \text { age }^{3}+0.005 . \text { age }^{4}-0.00002 . \text { age }^{5}
$$

Where he is the real health expenditure by age group, $N$ population by age group and age is the central point in each bracket (e.g., 2,7,12,...,97).

71. For each country, this expenditure curve by age group is multiplied by country-specific population by age group in order to obtain a total country-specific health expenditure. This expenditure is then calibrated to fit with the OECD database total expenditure in the base year.

\section{LTC Dependency ratios}

72. The dependency ratios (number of dependants by age group) were derived from the European Commission 2009 Ageing Report. Even if the shape of the dependency ratios by age differs across 
countries, the dispersion remains relatively limited (Figure 3.2 of main text). Accordingly, dependency ratios are assumed to be broadly uniform across countries and an average dependency ratio by age group was calculated and used in the projections. The dependency ratios are then projected using the evolution of life expectancy at birth and health expenditure (cost-containment scenario). The life expectancies at birth are those underlying official population projections.

\section{Macro data}

GDP

73. GDP projections are published in the OECD, Economic Outlook No. 91. More details regarding the sources and the methodology can be found in Box 1 and in Johansson et al., (2012). In short, GDP projections are based on a conditional convergence model.

\section{Population}

74. Population projections come from Eurostat for European Countries (EUROPOP2010) and from the United Nations for non-European Countries (World Population Prospects: The 2010 Revision).

\section{Health prices and technology}

75. The health price measure used in this paper is the value-added deflator in the health and social work sectors, taken from the OECD STAN database. Even if this measure may not be as accurate as needed, it is nonetheless more comparable across countries than more precise price indicators available from other sources. For instance, CPI series for the health sector can be gathered from Eurostat (for European countries) and national sources (for Australia, Canada, Korea, New Zealand and the United States). The CPI series cannot, however, be used because they are available for too short a period (the HICP from Eurostat is only available from 1996 onwards) and there is also a potential lack of comparability across countries.

76. The quality effect combines an indicator of patents with an indicator of R\&D statistics. The patents granted by the European Patent Office (EPO) have been chosen as they seem to generate substantially greater market power than their US equivalents (Bessen, 2012) and may represent the OECDwide technology frontier (see Appendix 2). They come from the OECD database on Patents. To benefit from advances in this frontier, countries need to innovate and absorb foreign technology (via technology pass-through and catching up effects). While not all $R \& D$ expenditures are medical, they may advance health care technology because of externalities (Okunade and Murthy (2002)); moreover, high R\&D spending is needed to enable the adoption of foreign technologies (the so-called absorption potential). Hence, the ratio of total R\&D expenditure to GDP has been used as a proxy for the ability of a country to reach the frontier. The data come from the OECD R\&D database.

\section{Baumol effect}

77. The "cost-disease" Baumol effect is proxied by the productivity growth in total economy. The productivity data come from the OECD Economic Outlook No. 91 and Johansson et al., (2012). It is calculated as real GDP per worker in 2005 constant PPP USD.

\section{Participation rate}

78. Participation rates are those underlying GDP projections and come from the OECD Economic Outlook No. 91 and Johansson et al., (2012). For OECD countries, the participation rates' projections are 
based on the so-called "cohort approach" (Burniaux et al., 2003). The cohort approach assumes that the observed participation behaviour of individuals belonging to the most recent cohorts, such as the lower exit rates of current old-age workers relative to previous cohorts, or the higher entry rates of current young women relative to previous cohorts, will continue to apply to future cohorts as well. Therefore, future participation rates are determined by the participation behaviour of the most recent cohorts and the evolution of the relative weight of different cohorts, which is driven by demographic developments (see Johansson et al., 2012 for more details).

79. Some policy reforms are taken into account into the labour force participation's projections. First, the long-term trend expansion in education - and the associated increase in average years of schooling - is assumed to continue in all countries. Second, longer life expectancy and health improvements raise the scope for policies that encourage higher labour market participation at older age. And finally, a number of countries have already implemented or plan to implement reforms aiming to extend working lives, including by increasing the legal age to get a full pension. Recently-legislated pension reforms that involve an increase in the normal retirement age by 2020 are assumed to be implemented as planned. ${ }^{14}$ (see Johansson et al., 2012 for more details).

14 The countries for which an adjustment on current exit rates of older workers are made include Australia, Belgium, Canada, Czech Republic, Germany, Spain, Estonia, France, the United Kingdom, Greece, Hungary, Ireland, Israel, Italy, Japan, New Zealand, Slovak Republic, Slovenia, Turkey and the United States. 


\section{APPENDIX 2. THE HEALTH PROJECTION FRAMEWORK}

\section{Health projection framework}

80. The health care projection framework is based on a (usual) non-linear demand function expressed in a per capita basis, as follows ${ }^{15}$ :

$$
\left(\frac{h e}{N}\right)=\alpha \cdot\left(\frac{P}{P_{Y}}\right)^{\beta} \cdot Q^{\gamma} \cdot\left(\frac{Y}{N}\right)^{\varepsilon}
$$

Where he denotes health care demand volumes (deflated for price and quality); $P$ are health care prices; $P_{Y}$ is the income deflator (or GDP deflator); $Q$ is a quality index for health care products; $Y$ real income (or real GDP); $N$ is total population, and $\alpha$ is a constant. The expected signs for the elasticities are:

Price elasticity: $\beta<0$

Quality elasticity: $\gamma>0$

Income elasticity: $\epsilon>0$

81. The relation between quality-adjusted health volumes $(h e)$ and health expenditures $(H E)$ is as follows:

$$
(h e)=\frac{H E}{(P / Q)}
$$

Using (A2) to express equation (1) in terms of nominal health expenditures $(H E)$ per capita, gives:

$$
\left(\frac{H E}{N}\right)=\left(\frac{P}{Q}\right) \cdot\left(\frac{h e}{N}\right)=\alpha \cdot \frac{P^{(1+\beta)}}{P_{Y} \beta} \cdot Q^{(\gamma-1)} \cdot\left(\frac{Y}{N}\right)^{\varepsilon}
$$

This nominal demand function can also be expressed as the ratio of health expenditures to GDP:

$$
\frac{H E}{P_{Y} \cdot Y}=\alpha \cdot\left(\frac{P}{P_{Y}}\right)^{(1+\beta)} \cdot Q^{(\gamma-1)} \cdot\left(\frac{Y}{N}\right)^{(\varepsilon-1)}
$$

Taking the logarithmic growth rates of equation (A4) one gets:

$$
\Delta \log \left(\frac{H E}{P_{Y} \cdot Y}\right)=(1+\beta) \cdot \Delta \log \left(\frac{P}{P_{Y}}\right)+(\gamma-1) \cdot \Delta \log (Q)+(\varepsilon-1) \cdot \Delta \log \left(\frac{Y}{N}\right)
$$

To be precise, the health quality effects in equation (A1) should also appear in relative terms vis-à-vis the overall quality of goods and services produced in the economy. In some countries, the GDP deflator includes already hedonic prices for some goods, but not yet for health. The effect of the relative quality will be partly captured in our empirical proxy for $Q$ (see below). 
82. Equation (A5) is the base health expenditure model used in this paper. In addition, it is also assumed that health spending depends on a drift factor related to demographic factors (demo). In the OECD (2006) projection framework, the effects of prices and quality (technology improvements) were not disentangled and an assumption was made on their combined effect, labelled "health expenditure residual" (Res). This approach is also followed in the current set of projections, as the components of the health expenditure residual are difficult to extrapolate in the future. During the projection period, it is assumed that the deflator $\left(P_{Y}\right)$ remains constant (i.e. there is no projection of economy-wide inflation), so equation (A5) becomes:

$$
\Delta \log \left(\frac{H E}{Y}\right)=\Delta \log (\text { demo })+\Delta \log (\text { Res })+(\varepsilon-1) \cdot \Delta \log \left(\frac{Y}{N}\right)
$$

This corresponds to equation (1) of the main text. To project health expenditures based on equation (A6), the values for the demographic effects, the expenditure residual and income effects need to be calibrated.

83. The calibration was done in different ways. The demographic effect is calculated using an accounting method and assumptions on the health status of the population, notably a so-called 'healthy ageing' regime (see Box 1 in the main text).

84. The 'health expenditure residual' is extrapolated as a whole. Its estimation is based on a growth accounting method, which decomposes the past average growth of health expenditures into observed age and income effects (assuming a given value for the income elasticity). This allows deriving the unexplained expenditure residual (Table 2.1 in the main text). To attempt an interpretation of this residual, an econometric equation has also been estimated, incorporating explicitly the effects of prices and a proxy for quality (see below).

85. Accordingly, the income elasticity, as well as the price and quality elasticities, were derived from a panel regression using equation (A1) above (in log terms and expressed in quality-adjusted health volumes per capita), augmented with the drift factors related to demography and exogenous policy factors captured by a time trend (e.g. institutional reforms increasing the coverage of the health coverage system):

$$
\log \left(\frac{h e}{N}\right)=\alpha_{c}+\theta \cdot \log (D e m o)+\beta \cdot \log \left(\frac{P}{P_{Y}}\right)+\gamma \cdot \log (Q)+\varepsilon \cdot \log \left(\frac{Y}{N}\right)+\tau \cdot T+u
$$

Where $\alpha_{c}$ correspond to country fixed-effects; $T$ to a time trend; and $u$ a randomly distributed residual. The equation was estimated both in levels and in first differences. The demographic effect is captured by the average age of the population. The quality effect $(Q)$ was loosely proxied by a ratio involving the relative pace of patent creation in the health sector compared with the rest of the economy for the average of OECD countries. This ratio is assumed to represent the change in the technology frontier. To capture country-specific effects related to the diffusion and adoption of technology, the ratio is multiplied by the share of R\&D expenditures in GDP:

$$
Q=\frac{\mathrm{R} \& D}{\mathrm{GDP}} \cdot \frac{\text { Total OECD Patents in the Health sector }}{\text { Total OECD patents }}
$$


86. The results of the econometric estimation are relatively robust, with the value of the income elasticity fluctuating from around 0.5 to close to 1 , depending on the specifications (see also Appendix 3 ). The preferred econometric estimate (col. 8 of Table A1.1) gives an estimated elasticity of 0.42 for relative prices $(\beta)$ and 0.91 for the technology/quality effect $(\gamma)$. Translating these into expenditure elasticities using equation (A5), respectively, $(\beta+1)$ and $(1-\gamma)$, and the observed growth rates of $\left(P / P_{Y}\right)$ and $(Q)$ the contribution of these variables to explaining the residual growth can be derived (see Box 3 ).

Table A2.1 Real public health care expenditure per capita: econometric estimates

\begin{tabular}{|c|c|c|c|c|c|c|c|c|c|c|}
\hline & Pooled & $\begin{array}{c}\text { Fixed } \\
\text { effects } \\
\text { with Time } \\
\text { dummies }\end{array}$ & $\begin{array}{c}\text { Fixed } \\
\text { effects } \\
\text { with Time } \\
\text { trend }\end{array}$ & $\begin{array}{c}\text { Fixed } \\
\text { effects } \\
\text { with Time } \\
\text { dummies }\end{array}$ & $\begin{array}{c}\text { Fixed } \\
\text { effects } \\
\text { with Time } \\
\text { trend }\end{array}$ & $\begin{array}{c}\text { Fixed } \\
\text { effects } \\
\text { with Time } \\
\text { dummies }\end{array}$ & $\begin{array}{c}\text { Fixed } \\
\text { effects } \\
\text { with Time } \\
\text { dummies }\end{array}$ & \begin{tabular}{|c|} 
Fixed \\
effects \\
with time \\
trend
\end{tabular} & $\begin{array}{l}\text { Income } \\
\text { elasticity } \\
=0.8\end{array}$ & $\begin{array}{c}\text { Memo item } \\
\text { First } \\
\text { differences } \\
\text { estimates }\end{array}$ \\
\hline log(gdpv per capita) & $\begin{array}{l}0.914^{* * *} \\
(0.02)\end{array}$ & $\begin{array}{l}0.394^{* *} \\
(0.18)\end{array}$ & $\begin{array}{l}0.495^{\star * *} \\
(0.13)\end{array}$ & $\begin{array}{l}0.775^{\star \star *} \\
(0.14)\end{array}$ & $\begin{array}{l}0.634^{* * *} \\
(0.14)\end{array}$ & $\begin{array}{l}0.964^{* * *} \\
(0.14)\end{array}$ & $\begin{array}{l}0.749^{* * *} \\
(0.12)\end{array}$ & $\begin{array}{l}0.532^{* \star *} \\
(0.12)\end{array}$ & & \\
\hline $\begin{array}{l}\text { log (average age of } \\
\text { population) }\end{array}$ & $\begin{array}{l}2.603^{* * *} \\
(0.56)\end{array}$ & $\begin{array}{l}3.007^{\star \star *} \\
(0.59)\end{array}$ & $\begin{array}{l}1.399^{\star \star *} \\
(0.45)\end{array}$ & $\begin{array}{l}1.396^{\star \star *} \\
(0.42)\end{array}$ & $\begin{array}{l}2.611^{* * *} \\
(0.46)\end{array}$ & $\begin{array}{l}2.606^{* * *} \\
(0.42)\end{array}$ & $\begin{array}{l}1.342^{* * *} \\
(0.41)\end{array}$ & $\begin{array}{l}1.471^{* * *} \\
(0.44)\end{array}$ & $\begin{array}{l}0.962^{\star *} \\
(0.43)\end{array}$ & \\
\hline timetr & & & $\begin{array}{l}0.009^{* * *} \\
(0.00)\end{array}$ & & $\begin{array}{l}0.009^{* * *} \\
(0.00)\end{array}$ & & & $\begin{array}{l}0.009^{* * *} \\
(0.00)\end{array}$ & $\begin{array}{l}0.001 \\
(0.00)\end{array}$ & \\
\hline $\log (G D P$ deflator) & & & $\begin{array}{l}0.453^{\star \star *} \\
(0.08)\end{array}$ & $\begin{array}{l}0.482^{\star * *} \\
(0.08)\end{array}$ & $\begin{array}{l}0.929^{* * *} \\
(0.06)\end{array}$ & $\begin{array}{l}0.777^{* * *} \\
(0.06)\end{array}$ & & & & \\
\hline log(Health prices) & & & $\begin{array}{l}-0.415^{* * *} \\
(0.07)\end{array}$ & $\begin{array}{l}-0.505^{\star * *} \\
(0.06)\end{array}$ & & & & & & \\
\hline lagged log(Technology) & & & $\begin{array}{l}0.908^{* * *} \\
(0.03)\end{array}$ & $\begin{array}{l}0.918^{* * *} \\
(0.04)\end{array}$ & & & $\begin{array}{l}0.919^{* * *} \\
(0.04)\end{array}$ & $\begin{array}{l}0.912^{* * *} \\
(0.03)\end{array}$ & $\begin{array}{l}0.930^{* * *} \\
(0.03)\end{array}$ & \\
\hline lagged dlog(Technology) & & & & & & & & & & $\begin{array}{l}1.027^{* * *} \\
(0.05)\end{array}$ \\
\hline $\begin{array}{l}\text { lagged log(quality ajusted } \\
\text { health prices) }\end{array}$ & & & & & $\begin{array}{l}-0.788^{* * *} \\
(0.03)\end{array}$ & $\begin{array}{l}-0.755^{* * *} \\
(0.03)\end{array}$ & & & & \\
\hline $\begin{array}{l}\text { log(Relative prices (Health } \\
\text { prices/PGDP)) }\end{array}$ & & & & & & & $\begin{array}{l}-0.503^{* * *} \\
(0.06)\end{array}$ & $\begin{array}{l}-0.415^{\star * *} \\
(0.07)\end{array}$ & $\begin{array}{l}-0.492^{\star * *} \\
(0.06)\end{array}$ & \\
\hline dlog(gdpv per capita) & & & & & & & & & & $\begin{array}{l}0.535^{\star * *} \\
(0.12)\end{array}$ \\
\hline $\begin{array}{l}\text { dlog (average age of } \\
\text { population) }\end{array}$ & & & & & & & & & & $\begin{array}{l}1.509 \\
(1.45)\end{array}$ \\
\hline $\begin{array}{l}\text { dlog(Relative prices (Health } \\
\text { prices/PGDP)) }\end{array}$ & & & & & & & & & & $\begin{array}{l}-0.626^{\star \star *} \\
(0.06)\end{array}$ \\
\hline _cons & $\begin{array}{l}-11.591^{* * *} \\
(2.08)\end{array}$ & $\begin{array}{l}-7.824^{* * *} \\
(2.19)\end{array}$ & $\begin{array}{l}-3.513^{* *} \\
(1.78)\end{array}$ & $\begin{array}{l}-5.889^{* * *} \\
(1.85)\end{array}$ & $\begin{array}{l}-7.535^{\star * *} \\
(1.86)\end{array}$ & $\begin{array}{l}-10.936^{* * *} \\
(1.90)\end{array}$ & $\begin{array}{l}-5.414^{* * *} \\
(1.54)\end{array}$ & $\begin{array}{l}-4.179^{* * *} \\
(1.54)\end{array}$ & $\begin{array}{l}-6.646^{* * *} \\
(1.38)\end{array}$ & $\begin{array}{l}0.006 \\
(0.02)\end{array}$ \\
\hline $\mathrm{N}$ & 474 & 474 & 463 & 463 & 453 & 453 & 463 & 463 & 463 & 447 \\
\hline r2 & 0.825 & 0.863 & 0.924 & 0.941 & 0.913 & 0.934 & 0.941 & 0.924 & 0.847 & 0.777 \\
\hline r2_a & 0.824 & 0.845 & 0.918 & 0.933 & 0.906 & 0.925 & 0.933 & 0.918 & 0.837 & 0.746 \\
\hline
\end{tabular}

Note: Projections are based on the estimates highlighted within the box 


\section{Adjustment for convergence effects}

87. The projection framework (equation A6 above) only projects the logarithmic growth rates of health expenditures to GDP and, as such, does not take into account possible convergence effects associated with differences in the levels of the ratio of health expenditures to GDP in the base period (2006-2010). Indeed, it seems natural that countries that display a rather low health expenditure ratio would tend to converge to OECD average levels. This is particularly important in the context of the projections that do not assume country-specific residual growth in expenditures or income elasticities (as in the baseline assumed in this paper), or for countries that have in the base year a very low level of spending, such as emerging economies.

88. Therefore, the projected (for period $t$ ) health spending ratios were adjusted as follows:

$$
\left(\frac{H E}{Y}\right)_{i, t}=\left[1+\left(\frac{(H E / Y)_{O E C D, 0}}{(H E / Y)_{i, 0}}\right) \cdot g_{i}\right] \cdot\left(\frac{H E}{Y}\right)_{i, 0}
$$

Where $g_{i}$ is the growth rate of health spending for country $i$ (from period 0 to period $\mathrm{t}$ ) derived from equation (A6); $\left(\frac{H E}{Y}\right)_{i, 0}$ is the health expenditure ratio for country $i$ in the base period; and, $\left(\frac{H E}{Y}\right)_{O E C D, 0}$ is the health expenditure ratio for the OECD average in the base period.

When the spending ratio of a given country is below (or above) the OECD average for the base year this adjustment will increase (decrease) the projected growth rate of expenditures to GDP, thus allowing for convergence to take place.

\section{Estimation of the survivor expenditure curve}

89. An average expenditure curve for survivors was estimated econometrically in a panel of 23 countries and 20 age groups, using a spline function as follows:

$$
\frac{\text { he age group }}{N_{\text {age group }}}=-199.1 . \text { age }+14.5 . \text { ag }^{2}-0.41 . \text { age }^{3}+0.005 . \text { age }^{4}-0.00002 . \text { age }^{5}
$$

Where he is the real health expenditure by age group, $N$ population by age group and age is the central point in each bracket (e.g., 2,7,12,..,97)

For each country, this expenditure curve by age group is multiplied by country-specific population by age group in order to obtain a total country-specific health expenditure. This expenditure is then calibrated to the OECD database total expenditure in the base year. 


\section{APPENDIX 3: INCOME ELASTICITY: REVIEW OF LITERATURE}

90. Whether health care is a luxury (income elasticity above one) or a necessity (elasticity below one) remains an unsettled issue. Since Newhouse (1977), a large part of the economic literature attempts to estimate this elasticity. Getzen (2000) argues that the higher the level of aggregation the higher the income elasticity of health care spending. Table A3.1 provides a summary of several studies. At the individual level the elasticity is found to be below one while at the macro level studies show elasticities greater than one.

91. Getzen (2000) argues that empirical studies often failed to distinguish between sources of variation between groups and within groups: an individual within an insured group may have little incentive to limit health expenditures, especially if the group is large and the individual's effect on the group is insignificant. Thus, an individual's health care spending is insensitive to income. By contrast, the group's total expenditure on health care is limited by its aggregate income. Total group spending will be more responsive to income than individual spending, and wider groups will be even more responsive. See OECD (2006) for a detailed review of these studies.

92. Dormont et al., (2011) presented new evidence on the elasticity of per capita public, private and total health care services. They argue that the income elasticity depends on the type of health care spending. Using pooled OLS estimation, they found income elasticity below or close to one in the case of per capita private health expenditures, whereas it exceeds one when considering per capita public or total health expenditures. The inclusion of a common trend or time dummies over sub-periods leads to a decrease of the latter income elasticity, though it remains largely above one.

93. These cross-sectional estimates use an implicit assumption of homogeneity across countries that seems unrealistic. To address this drawback the authors use panel estimation techniques. When controlling for individual fixed-effects, the inclusion of a common time trend significantly reduces the income elasticity to below one. This result is more robust than that of the pooled OLS. Testing a one-way error component model in the individual variables for each type of per capita health care expenditure, the authors find results that are fairly close to those of the one-way fixed effects model. Overall, results confirm that the inclusion of a common trend significantly lowers the income elasticity (below one). 
ECO/WKP(2013)40

Table A3.1. Survey of income elasticity estimates of health-care expenditures (or utilisation) by level of observation

\begin{tabular}{|c|c|}
\hline INDIVIDUALS (micro) & Income elasticity \\
\hline \multicolumn{2}{|l|}{ General (insured/mixed) } \\
\hline Newhouse and Phelps (1976) & $\leq 0.1$ \\
\hline $\operatorname{AMA}(1978)$ & $\approx 0$ \\
\hline Sunshine and Dicker (1987) & $\approx 0$ \\
\hline Manning et al. (1987) & $\approx 0$ \\
\hline Wedig (1988) & $\approx 0$ \\
\hline Wagstaff et al. (1991) & $\leq 0$ \\
\hline Hahn and Lefkowitz (1992) & $\leq 0$ \\
\hline AHCPR (1997) & $\leq 0$ \\
\hline \multicolumn{2}{|l|}{ Special / uninsured } \\
\hline Falk et al. (1933) & 0.7 \\
\hline Weeks (1961) & 0.3 \\
\hline Anderson et al. (1960) (1953 data) & 0.4 \\
\hline Anderson et al. (1960) (1958 data) & 0.2 \\
\hline \multicolumn{2}{|l|}{ Other } \\
\hline USPHS (1960) (physician visits) & 0.1 \\
\hline USPHS (1960) (dental visits) & 0.8 \\
\hline AMA (1978) (dental expenses) & $1.0-1.7$ \\
\hline Andersen and Benham (1970) (physician expenses) & 0.4 \\
\hline Andersen and Benham (1970) (dental expenses) & 1.2 \\
\hline Silver (1970) (physician expenses) & 0.85 \\
\hline Silver (1970) (dental expenses) & $2.4-3.2$ \\
\hline Newman and Anderson (1972) (dental expenses) & 0.8 \\
\hline Feldstein (1973) (dental expenses) & 1.2 \\
\hline Scanlon (1980) (Nursing home expenses) & 2.2 \\
\hline Sunshine and Dicker (1987) (dental expenses) & $0.7-1.5$ \\
\hline Hahn and Lefkowitz (1992) (dental expenses) & 1.0 \\
\hline AHCPR (1997) (dental expenses) & 1.1 \\
\hline Parker and Wong (1997) (Mexico, total expenses) & $0.9-1.6$ \\
\hline \multicolumn{2}{|l|}{$\begin{array}{l}\text { REGIONS (intermediate) } \\
\end{array}$} \\
\hline Feldstein (1971) (47 states, 1958-1967, \$hospital) & 0.5 \\
\hline Fuchs and Kramer (1972) (33 states, 1966, \$physician) & 0.9 \\
\hline Levit (1982) (50 states, 1966,1978, \$total) & 0.9 \\
\hline McLauglin (1987) (25 SMSAs, 1972-1982, \$hospital) & 0.7 \\
\hline Baker (1997) (3073 US counties, 1986-1990, \$Medicare) & 0.8 \\
\hline Di Matteo and Di Matteo (1998) (10 Canadian provinces 1965-1991) & 0.8 \\
\hline \multicolumn{2}{|l|}{$\begin{array}{l}\text { NATIONS (macro) } \\
\end{array}$} \\
\hline Abel-Smith (1967) (33 countries, 1961) & 1.3 \\
\hline Kleiman (1974) (16 countries, 1968) & 1.2 \\
\hline Newhouse (1977) (13 countries, 1972) & 1.3 \\
\hline Maxwell (1981) (10 countries, 1975) & 1.4 \\
\hline Gertler and van der Gaag (1990) (25 countries, 1975) & 1.3 \\
\hline Getzen (1990) (US, 1966-1987) & 1.6 \\
\hline Schieber (1990) (seven countries, 1960-1987) & 1.2 \\
\hline Gerdtham et al. (1992) (19 countries, 1987) & 1.2 \\
\hline Getzen and Poullier (1992) (19 countries, 1965-1986) & 1.4 \\
\hline Fogel (1999) (United States, long run) & 1.6 \\
\hline
\end{tabular}

Source: Getzen (2000). 


\section{Potential bias in the estimation}

94. The estimation of income elasticity may be biased for several reasons. The omission of variables (for instance, technological progress) may bias the estimation upward. Similarly, a misleading specification used to estimate the parameter may also provide biased results. For instance, a vast literature stresses that the results are strongly dependent on the non-stationarity and co-integration properties of the variables. Moreover, the causal relationship between income and health is not always well defined.

95. Despite the empirical evidence suggesting a long-run relationship between health expenditure and income, there is a risk for omitted variables. Recent studies have indicated that the observed increasing health care expenditure as a share of GDP may also be due to other factors, such as technological change or insurance coverage (Hall and Jones, 2007; Okunade and Murthy, 2002; Blomqvist and Carter, 1997). Technological advances could provide an explanation for the high estimates of income elasticity found at the macro level in the literature. On the other hand, Di Matteo and Di Matteo (1998) argue that because health care is labour intensive, its cost may increase as a function of average income, so that measured income elasticity is blurred by the price effect. Since the price elasticity is presumably negative, the income coefficient is likely to be biased downward.

96. According to Acemoglu et al., (2009), most of the studies are based on simple correlations between income and health expenditure across individuals, across countries and over time. Their study provides causal estimates of the effect of income on aggregate health spending in US regions. Their strategy is to instrument local area income with the variation of oil prices weighted by oil reserves. Their central estimate for the income elasticity is 0.7 , with a maximum bound at $95 \%$ interval of 1.1 . This result is robust to different specifications with the elasticity being almost always below one (see Table A3.2).

97. Using a dataset of health care expenditures and disposable personal income for the states in the United States over the years 1986-1998, Freeman (2003) finds that health care expenditures and incomes at state level are non-stationary and co-integrated and estimated income elasticity of health care at 0.817 to 0.844. These findings are close to the estimates of Di Matteo and Di Matteo (1998) for Canadian provincial data.

98. Moscone and Tosetti (2010) investigated the long-run economic relationship between health care expenditure and income in the United States at state level. Their estimation controls for cross-section dependence and unobserved heterogeneity. As others in the literature they find health expenditure and income to be non-stationary and co-integrated. Their elasticity estimates across states vary widely. However in the majority of them, the elasticity is lower than one. Their result suggests that health is a necessity rather than a luxury.

99. According to Atella and Marini (2004), the disagreement about income elasticity comes from two sources: the inclusion of specific regressors and functional specification used to estimate the parameter. Their survey does not find a single answer to the question of the value of the elasticity. When assuming homoskedasticity and no-correlation in errors, the authors find elasticities always greater than unity. Under the assumption of heteroskedastic and autocorrelated errors and of cross-country correlation, income elasticities are found to be lower than one.

100. Using panel co-integration techniques, Dreger and Reimers (2005) incorporate medical progress in their model, proxied by variables such as life expectancy or infant mortality. They find that the income elasticity should not be too different from one. This result confirms that the income elasticity may be biased upward if the role of technology is not taken into account. 
101. According to Baltagi and Moscone (2010), while income has been recognised as an important determinant of health care spending, there is no consensus on which other factors may influence health expenditure. Using a panel of 20 OECD countries, the authors studied the non-stationarity and cointegration properties of health expenditure and income. Their findings suggest that health care is a necessity rather than a luxury with estimated income elasticities much smaller than in other studies.

102. Using a co-integrated panel data regression approach, Bech et al., (2011) derived short-run as well as long-run relationships between health expenditure and explanatory variables in the EU-15 countries. Among those explanatory variables are economic, social, demographic and institutional variables and also variables related to capacity and production technology in the health care sector. They find life expectancy to be a more important driver than ageing. Regarding income, after having checked that both GDP and health expenditure are non-stationary, the authors show that the two variables are cointegrated. They find a unitary income elasticity of health care accounting for the dynamic structure of the relationship between health expenditure and GDP.

103. Narayan et al., (2011) examine whether health-care expenditure is a luxury or a necessity for OECD countries within a panel unit root and panel co-integration framework. They first calculate real health expenditure using the GDP deflator, and then they use a specific health-care price index. Based on real expenditure deflated by the GDP deflator, they find that both health expenditure and GDP contain a panel unit root and are co-integrated when a time trend is included in the model. The authors find that GDP has a positive and statistically significant effect on health but obtain mixed results concerning the income elasticity by country. For the panel as a whole the income elasticity is around one. Based on real expenditure deflated by the health deflator, GDP and health spending are found to be non-stationary and co-integrated with and without a trend. For the panel as a whole the elasticity of health with respect to GDP is less than one. The fact that the coefficients on GDP have changed when the GDP deflator is replaced by an health price index casts doubt on the reliability of the results using the GDP deflator. The authors conclude that there is no support for the proposition that health care is a luxury.

Table A3.2. Selected recent income elasticity estimates of health care expenditures

\begin{tabular}{lc}
\hline Papers & Elas ticity \\
\hline Acemoglu et al. (2009) & $\approx 0.7$ \\
Baltagi and Moscone (2010) & $<1$ \\
Bech et al. (2011) & $\approx 1$ \\
Dreger and Reimers (2005) & $\approx 1$ \\
Dormont et al. (2011) & $>1$ \\
Freeman (2003) (US States level) & $\approx 0.8$ \\
Holly et al. (2011) & 0.75 to 0.95 \\
Moscone and Tosetti (2010) (US States level) & $<1$ \\
Narayan et. al (2011) & $\approx 1$ \\
$\quad$ HE deflated by PGDP & $<1$ \\
$\quad$ HE deflated by Health price & \\
\hline
\end{tabular}

Source: Authors' compilation.

104. An interesting paper from Costa-Font et al., (2011) tests the luxury good hypothesis of health care by taking into account publication selection and aggregation bias. The authors use a meta-regression analysis on 167 comparable elasticity estimates from a set of 48 published studies and control for the standard error of each elasticity estimate (so-called precision), publication selection or the specific journal where the study was published and aggregation nature of the data. Their results suggest that publication bias exists, more prestigious journals exhibiting tendency to report larger elasticity effects. After removing 
the publication bias, they find an income elasticity estimate that ranges between 0.4 and 0.8 which contradicts the luxury good hypothesis. Regarding aggregation, it seems that studies using regional data found lower income elasticities.

105. This non-exhaustive literature review suggests that whether health care is a luxury or a necessity remains an unsettled issue. Results partly depend on the other determinants of health spending that are taken into account in the estimation and on the econometric techniques that are used. Nevertheless, a number of recent studies are leaning towards the result that the health care income elasticity is below one and this is also coherent with estimates presented in this paper. 


\section{APPENDIX 4. ESTIMATIONS TO CALIBRATE THE LTC FRAMEWORK}

Table A4.1. Dependency ratio: econometric estimates

\begin{tabular}{|c|c|c|c|}
\hline \multicolumn{4}{|l|}{ Dependent variable } \\
\hline \multicolumn{4}{|c|}{ Ratio of dependents by age group } \\
\hline & (1) & (2) & (3) \\
\hline & Pooled & Fixed effects & Random effects \\
\hline \multirow[t]{2}{*}{ Age } & $6.072^{\star \star \star}$ & $5.709^{* * *}$ & $5.926^{* * *}$ \\
\hline & $(0.16)$ & $(0.19)$ & $(0.17)$ \\
\hline \multirow[t]{2}{*}{ Health expenditure } & $0.189^{* * *}$ & $0.449^{* * *}$ & $0.294^{* * *}$ \\
\hline & $(0.05)$ & $(0.10)$ & $(0.08)$ \\
\hline \multirow[t]{2}{*}{ Life expectancy at birth } & $-6.270^{\star * *}$ & . & $-7.421^{\star * *}$ \\
\hline & $(1.37)$ & . & $(1.68)$ \\
\hline \multirow[t]{2}{*}{ cons } & 2.515 & $-25.467^{\star \star \star}$ & 7.330 \\
\hline & $(6.13)$ & $(0.62)$ & $(7.30)$ \\
\hline $\mathrm{N}$ & 180.000 & 180.000 & 180.000 \\
\hline \multicolumn{4}{|c|}{ Standard errors in parentheses } \\
\hline$=" * p<0.10$ & ${ }^{* *} p<0.05$ & ${ }^{* * *} p<0.01 "$ & \\
\hline
\end{tabular}

Table A4.2. LTC expenditure: econometric estimates

Dependent variable : LTC as a \% of GDP

\begin{tabular}{|c|c|c|c|c|c|}
\hline & Pooled & Pooled & Pooled & Pooled & Pooled \\
\hline $\begin{array}{l}\text { Old age dependency ratio } \\
\text { (People aged } 80 \text { and plus) }\end{array}$ & $\begin{array}{l}2.359^{* \star *} \\
(0.18)\end{array}$ & $\begin{array}{l}2.308^{* * *} \\
(0.17)\end{array}$ & $\begin{array}{l}1.553^{\star \star \star} \\
(0.18)\end{array}$ & $\begin{array}{l}1.668^{* * *} \\
(0.17)\end{array}$ & $\begin{array}{l}1.645^{\star \star \star} \\
(0.19)\end{array}$ \\
\hline $\begin{array}{l}\text { Participation rate of women } \\
\text { aged } 50-64\end{array}$ & & $\begin{array}{l}0.419^{\star *} \\
(0.18)\end{array}$ & $\begin{array}{l}0.704^{\star * *} \\
(0.17)\end{array}$ & $\begin{array}{l}0.382^{\star *} \\
(0.18)\end{array}$ & \\
\hline Productivity (total economy) & & & $\begin{array}{l}2.073^{* * *} \\
(0.25)\end{array}$ & & $\begin{array}{l}2.107^{* * *} \\
(0.29)\end{array}$ \\
\hline GDP per capita & & & & $\begin{array}{l}1.682^{* * *} \\
(0.19)\end{array}$ & \\
\hline $\begin{array}{l}\text { Exit rate from employment of } \\
\text { women aged } 50-64\end{array}$ & & & & & $\begin{array}{l}-0.144^{*} \\
(0.08)\end{array}$ \\
\hline _cons & $\begin{array}{l}7.243^{* * *} \\
(0.59)\end{array}$ & $\begin{array}{l}7.346^{* * *} \\
(0.58)\end{array}$ & $\begin{array}{l}-17.802^{\star \star \star} \\
(3.06)\end{array}$ & $\begin{array}{l}-12.065^{* * *} \\
(2.27)\end{array}$ & $\begin{array}{l}-18.696^{\star \star \star} \\
(3.53)\end{array}$ \\
\hline$N$ & 360.000 & 355.000 & 340.000 & 340.000 & 298.000 \\
\hline $\begin{array}{l}\text { Standard errors in parentheses } \\
="{ }^{*} p<0.10\end{array}$ & ${ }^{* *} p<0.05$ & ${ }^{* * *} p<0.0$ & & & \\
\hline
\end{tabular}


APPENDIX 5. DETAILED SCENARIO RESULTS FOR HEALTH AND LONG-TERM CARE

Table A5.1. Breakdown of the projections of public health care expenditure for each driver

\begin{tabular}{|c|c|c|c|c|c|c|c|c|c|c|c|c|c|c|}
\hline & $\begin{array}{c}\text { Health } \\
\text { expenditure } \\
\text { as a \% of } \\
\text { GDP }\end{array}$ & $\begin{array}{l}\text { Death- } \\
\text { related } \\
\text { costs }\end{array}$ & $\begin{array}{l}\text { Pure age } \\
\text { effect } \\
\text { (survivors) }\end{array}$ & $\begin{array}{l}\text { Adjustment } \\
\text { for healthy } \\
\text { ageing }\end{array}$ & $\begin{array}{l}\text { Income } \\
\text { effect }\end{array}$ & $\begin{array}{c}\text { Non-ageing } \\
\text { residual } \\
\text { effect }\end{array}$ & Total & $\begin{array}{l}\text { Death- } \\
\text { related } \\
\text { costs }\end{array}$ & $\begin{array}{l}\begin{array}{c}\text { Pure age } \\
\text { effect } \\
\text { (surivivors) }\end{array}\end{array}$ & $\begin{array}{l}\text { Adjustment } \\
\text { for healthy } \\
\text { ageing }\end{array}$ & $\begin{array}{l}\text { Income } \\
\text { effect }\end{array}$ & $\begin{array}{c}\text { Non-ageing } \\
\text { residual } \\
\text { effect }\end{array}$ & Total & \begin{tabular}{|c|} 
Health \\
expenditure \\
as a \% of \\
GDP
\end{tabular} \\
\hline & $\begin{array}{c}\text { Average } \\
2006-2010\end{array}$ & \multicolumn{6}{|c|}{ Increase in \% points of GDP 2010-2030 } & \multicolumn{6}{|c|}{ Increase in \% points of GDP 2010-2060 } & 2060 \\
\hline Australia & 5.6 & 0.2 & 0.5 & -0.3 & 0.0 & 0.0 & 0.4 & 0.5 & 1.0 & -0.6 & 0.0 & 0.0 & 0.8 & 6.4 \\
\hline Austria & 6.6 & 0.2 & 0.5 & -0.3 & 0.0 & 0.0 & 0.4 & 0.4 & 1.0 & -0.9 & 0.0 & 0.0 & 0.6 & 7.2 \\
\hline Belgium & 5.8 & 0.2 & 0.3 & -0.3 & 0.0 & 0.0 & 0.2 & 0.3 & 0.7 & -0.8 & 0.0 & 0.0 & 0.2 & 6.0 \\
\hline Canada & 5.8 & 0.3 & 0.6 & -0.3 & 0.0 & 0.0 & 0.6 & 0.5 & 0.9 & -0.7 & 0.0 & 0.0 & 0.7 & 6.6 \\
\hline Chile & 3.1 & 0.4 & 0.8 & -0.2 & 0.0 & 0.0 & 0.9 & 0.7 & 1.8 & -0.7 & 0.0 & 0.0 & 1.8 & 4.9 \\
\hline Czech Republic & 5.5 & 0.3 & 0.6 & -0.4 & 0.0 & 0.0 & 0.4 & 0.5 & 1.2 & -1.0 & 0.0 & 0.0 & 0.7 & 6.2 \\
\hline Denmark & 6.3 & 0.2 & 0.5 & -0.3 & 0.0 & 0.0 & 0.4 & 0.3 & 0.8 & -0.8 & 0.0 & 0.0 & 0.3 & 6.5 \\
\hline Estonia & 4.3 & 0.2 & 0.4 & -0.4 & 0.0 & 0.0 & 0.2 & 0.3 & 1.1 & -0.8 & 0.0 & 0.0 & 0.6 & 4.9 \\
\hline Finland & 5.2 & 0.2 & 0.5 & -0.4 & 0.0 & 0.0 & 0.4 & 0.3 & 0.7 & -0.7 & 0.0 & 0.0 & 0.3 & 5.6 \\
\hline France & 7.4 & 0.1 & 0.5 & -0.3 & 0.0 & 0.0 & 0.3 & 0.3 & 0.8 & -0.8 & 0.0 & 0.0 & 0.3 & 7.7 \\
\hline $\begin{array}{l}\text { Germany } \\
\text { Greece }\end{array}$ & $\begin{array}{l}7.3 \\
5.4\end{array}$ & $\begin{array}{l}0.2 \\
0.2\end{array}$ & $\begin{array}{l}0.6 \\
0.4\end{array}$ & $\begin{array}{l}-0.4 \\
-0.3\end{array}$ & $\begin{array}{l}0.0 \\
0.0\end{array}$ & $\begin{array}{l}0.0 \\
0.0\end{array}$ & $\begin{array}{l}0.5 \\
0.3\end{array}$ & $\begin{array}{l}0.4 \\
0.4\end{array}$ & $\begin{array}{l}1.0 \\
1.0\end{array}$ & $\begin{array}{l}-0.9 \\
-0.8\end{array}$ & $\begin{array}{l}0.0 \\
0.0\end{array}$ & $\begin{array}{l}0.0 \\
0.0\end{array}$ & $\begin{array}{l}0.6 \\
0.7\end{array}$ & $\begin{array}{l}7.8 \\
6.0\end{array}$ \\
\hline Hungary & $\begin{array}{l}.4 .4 \\
4.8\end{array}$ & 0.2 & $\begin{array}{l}0.4 \\
0.5\end{array}$ & -0.5 & 0.0 & 0.0 & 0.2 & 0.4 & 1.3 & -1.3 & 0.0 & 0.0 & 0.4 & 5.2 \\
\hline Iceland & 5.8 & 0.0 & 0.5 & -0.3 & 0.0 & 0.0 & 0.3 & 0.1 & 0.7 & -0.6 & 0.0 & 0.0 & 0.2 & 6.1 \\
\hline Israel & 4.0 & 0.2 & 0.4 & -0.3 & 0.0 & 0.0 & 0.3 & 0.5 & 0.9 & -0.7 & 0.0 & 0.0 & 0.7 & 4.8 \\
\hline Ireland & 5.5 & 0.1 & 0.5 & -0.3 & 0.0 & 0.0 & 0.3 & 0.3 & 1.0 & -0.8 & 0.0 & 0.0 & 0.5 & 6.1 \\
\hline Italy & 6.1 & 0.2 & 0.4 & -0.3 & 0.0 & 0.0 & 0.3 & 0.4 & 1.0 & -0.7 & 0.0 & 0.0 & 0.7 & 6.8 \\
\hline Japan & 6.1 & 0.3 & 0.7 & -0.3 & 0.0 & 0.0 & 0.6 & 0.4 & 1.0 & -0.7 & 0.0 & 0.0 & 0.8 & 6.9 \\
\hline Korea & 3.3 & 0.4 & 1.1 & -0.4 & 0.0 & 0.0 & 1.1 & 0.8 & 2.1 & -0.8 & 0.0 & 0.0 & 2.0 & 5.4 \\
\hline Luxembourg & 4.4 & 0.2 & 0.5 & -0.3 & 0.0 & 0.0 & 0.4 & 0.5 & 1.1 & -0.9 & 0.0 & 0.0 & 0.7 & 5.1 \\
\hline $\begin{array}{l}\text { Mexico } \\
\text { Netherlands }\end{array}$ & $\begin{array}{l}2.5 \\
6.4\end{array}$ & $\begin{array}{l}0.2 \\
0.3\end{array}$ & $\begin{array}{l}0.7 \\
0.6\end{array}$ & $\begin{array}{l}-0.3 \\
-0.3\end{array}$ & $\begin{array}{l}0.0 \\
0.0\end{array}$ & $\begin{array}{l}0.0 \\
0.0\end{array}$ & $\begin{array}{l}0.6 \\
0.6\end{array}$ & $\begin{array}{l}0.5 \\
0.4\end{array}$ & $\begin{array}{l}2.0 \\
1.0\end{array}$ & $\begin{array}{l}-0.9 \\
-0.8\end{array}$ & $\begin{array}{l}0.0 \\
0.0\end{array}$ & $\begin{array}{l}0.0 \\
0.0\end{array}$ & $\begin{array}{l}1.6 \\
0.7\end{array}$ & $\begin{array}{l}4.2 \\
7.1\end{array}$ \\
\hline New Zealand & 6.4 & 0.3 & $\begin{array}{l}.0 \\
0.5\end{array}$ & $\begin{array}{l}-0.5 \\
-0.3\end{array}$ & 0.0 & 0.0 & $\begin{array}{l}.0 \\
0.5\end{array}$ & 0.5 & 1.0 & $\begin{array}{l}-0.0 \\
-0.6\end{array}$ & 0.0 & 0.0 & 0.8 & 7.2 \\
\hline Norway & 5.1 & 0.2 & 0.4 & -0.3 & 0.0 & 0.0 & 0.3 & 0.4 & 0.8 & -0.7 & 0.0 & 0.0 & 0.5 & 5.6 \\
\hline Poland & 4.1 & 0.3 & 0.7 & -0.5 & 0.0 & 0.0 & 0.4 & 0.5 & 1.7 & -1.3 & 0.0 & 0.0 & 1.0 & 5.1 \\
\hline Portugal & 6.5 & 0.2 & 0.5 & -0.4 & 0.0 & 0.0 & 0.4 & 0.5 & 1.2 & -0.9 & 0.0 & 0.0 & 0.8 & 7.3 \\
\hline Slovak Republic & 5.4 & 0.3 & 0.7 & -0.5 & 0.0 & 0.0 & 0.5 & 0.7 & 1.8 & -1.4 & 0.0 & 0.0 & 1.1 & 6.5 \\
\hline Slovenia & 5.2 & 0.3 & 0.6 & -0.4 & 0.0 & 0.0 & 0.5 & 0.5 & 1.2 & -0.7 & 0.0 & 0.0 & 1.0 & 6.2 \\
\hline Spain & 5.6 & 0.2 & 0.5 & -0.3 & 0.0 & 0.0 & 0.4 & 0.5 & 1.3 & -0.8 & 0.0 & 0.0 & 1.0 & 6.6 \\
\hline Sweden & 6.6 & 0.2 & 0.3 & -0.3 & 0.0 & 0.0 & 0.2 & 0.3 & 0.6 & -0.7 & 0.0 & 0.0 & 0.3 & 6.8 \\
\hline Switzerland & 5.7 & 0.2 & 0.5 & -0.3 & 0.0 & 0.0 & 0.4 & 0.5 & 1.1 & -0.8 & 0.0 & 0.0 & 0.9 & 6.6 \\
\hline Turkey & 3.8 & 0.4 & 0.7 & -0.3 & 0.0 & 0.0 & 0.7 & 0.8 & 1.9 & -1.0 & 0.0 & 0.0 & 1.8 & 5.6 \\
\hline $\begin{array}{l}\text { United Kingdom } \\
\text { United States }\end{array}$ & $\begin{array}{l}6.5 \\
7.1\end{array}$ & $\begin{array}{l}0.1 \\
0.2\end{array}$ & $\begin{array}{l}0.3 \\
0.5\end{array}$ & $\begin{array}{l}-0.3 \\
-0.3\end{array}$ & $\begin{array}{l}0.0 \\
0.0\end{array}$ & $\begin{array}{l}0.0 \\
0.0\end{array}$ & $\begin{array}{l}0.2 \\
0.4\end{array}$ & $\begin{array}{l}0.3 \\
0.3\end{array}$ & $\begin{array}{l}0.7 \\
0.7\end{array}$ & $\begin{array}{l}-0.7 \\
-0.6\end{array}$ & $\begin{array}{l}0.0 \\
0.0\end{array}$ & $\begin{array}{l}0.0 \\
0.0\end{array}$ & $\begin{array}{l}0.2 \\
0.5\end{array}$ & $\begin{array}{l}6.8 \\
7.5\end{array}$ \\
\hline United States & 7.1 & 0.2 & 0.5 & -0.3 & 0.0 & $\begin{array}{l}0.0 \\
0.0\end{array}$ & 0.4 & 0.3 & 0.7 & -0.6 & 0.0 & 0.0 & 0.5 & $\begin{array}{l}7.5 \\
6.2\end{array}$ \\
\hline$O E C D$ average ${ }^{1}$ & 5.5 & 0.2 & 0.5 & -0.4 & 0.0 & 0.0 & 0.4 & 0.4 & 1.1 & -0.8 & 0.0 & 0.0 & 0.8 & 6.2 \\
\hline $\begin{array}{l}\text { Brazil } \\
\text { China }\end{array}$ & $\begin{array}{l}3.7 \\
1.9\end{array}$ & $\begin{array}{l}0.3 \\
0.4\end{array}$ & $\begin{array}{l}0.8 \\
0.9\end{array}$ & $\begin{array}{l}-0.3 \\
-0.4\end{array}$ & $\begin{array}{l}0.0 \\
0.0\end{array}$ & $\begin{array}{l}0.0 \\
0.0\end{array}$ & $\begin{array}{l}0.8 \\
0.9\end{array}$ & $\begin{array}{l}0.6 \\
0.7\end{array}$ & 2.1 & $\begin{array}{l}-1.0 \\
-11\end{array}$ & $\begin{array}{l}0.0 \\
0.0\end{array}$ & $\begin{array}{l}0.0 \\
0.0\end{array}$ & $\begin{array}{l}1.7 \\
1.7\end{array}$ & $\begin{array}{l}5.4 \\
3.6\end{array}$ \\
\hline India & $\begin{array}{l}1.9 \\
1.2\end{array}$ & $\begin{array}{l}.4 \\
0.2\end{array}$ & $\begin{array}{l}0.9 \\
0.5\end{array}$ & $\begin{array}{l}-0.4 \\
-0.4\end{array}$ & $\begin{array}{l}0.0 \\
0.0\end{array}$ & $\begin{array}{l}.0 \\
0.0\end{array}$ & $\begin{array}{l}0.9 \\
0.3\end{array}$ & 0.6 & $\begin{array}{l}2.0 \\
1.5\end{array}$ & $\begin{array}{l}-1.1 \\
-1.2\end{array}$ & $\begin{array}{l}0.0 \\
0.0\end{array}$ & 0.0 & $\begin{array}{l}1.1 \\
0.9\end{array}$ & $\begin{array}{l}3.6 \\
2.1\end{array}$ \\
\hline Indonesia & 1.2 & 0.3 & 0.7 & -0.4 & 0.0 & 0.0 & 0.6 & 0.7 & 2.0 & -1.3 & 0.0 & 0.0 & 1.3 & 2.5 \\
\hline Russia & 3.1 & 0.2 & 0.4 & -0.4 & 0.0 & 0.0 & 0.1 & 0.3 & 0.9 & -1.0 & 0.0 & 0.0 & 0.2 & 3.3 \\
\hline South Africa & 3.2 & 0.1 & 0.4 & -0.5 & 0.0 & 0.0 & 0.0 & 0.3 & 1.1 & -1.4 & 0.0 & 0.0 & 0.0 & 3.2 \\
\hline Non-OECD average ${ }^{1}$ & 2.4 & 0.2 & 0.6 & -0.4 & 0.0 & 0.0 & 0.5 & 0.5 & 1.6 & -1.2 & 0.0 & 0.0 & 1.0 & 3.4 \\
\hline Total average ${ }^{1}$ & 5.0 & 0.2 & 0.5 & -0.4 & 0.0 & 0.0 & 0.4 & 0.5 & 1.2 & -0.9 & 0.0 & 0.0 & 0.8 & 5.8 \\
\hline
\end{tabular}


Table A5.2. Breakdown of the projections of public health care expenditure for each driver

ECO/WKP(2013)40

Cost-pressure scenario

\begin{tabular}{|c|c|c|c|c|c|c|c|c|c|c|c|c|c|c|}
\hline & $\begin{array}{c}\text { Health } \\
\text { expenditure } \\
\text { as a } \% \text { of } \\
\text { GDP }\end{array}$ & $\begin{array}{l}\text { Death- } \\
\text { related } \\
\text { costs }\end{array}$ & $\begin{array}{c}\begin{array}{c}\text { Pure age } \\
\text { effect } \\
\text { (survivors) }\end{array}\end{array}$ & $\begin{array}{l}\text { Adjustment } \\
\text { for healthy } \\
\text { aging }\end{array}$ & $\begin{array}{l}\text { Income } \\
\text { effect }\end{array}$ & $\begin{array}{c}\text { Non-ageing } \\
\text { residual } \\
\text { effect }\end{array}$ & Total & $\begin{array}{l}\text { Death- } \\
\text { related } \\
\text { costs }\end{array}$ & $\begin{array}{c}\begin{array}{c}\text { Pure age } \\
\text { effect } \\
\text { (survivors) }\end{array}\end{array}$ & $\begin{array}{l}\text { Adjustment } \\
\text { for healthy } \\
\text { ageing }\end{array}$ & $\begin{array}{l}\text { Income } \\
\text { effect }\end{array}$ & $\begin{array}{c}\text { Non-ageing } \\
\text { residual } \\
\text { effect }\end{array}$ & Total & \begin{tabular}{|c} 
Health \\
expenditure \\
as a \% of \\
GDP
\end{tabular} \\
\hline & $\begin{array}{c}\text { Average } \\
2006-2011\end{array}$ & \multicolumn{6}{|c|}{ Increase in \% points of GDP 2010-2030 } & \multicolumn{6}{|c|}{ Increase in \% points of GDP 2010-2060 } & 2060 \\
\hline Australia & 5.6 & 0.2 & 0.5 & -0.3 & -0.4 & 1.9 & 2.0 & 0.5 & 1.0 & -0.6 & -0.8 & 6.3 & 6.3 & 12.0 \\
\hline Austria & 6.6 & 0.2 & 0.5 & -0.3 & -0.2 & 1.9 & 2.1 & 0.4 & 1.0 & -0.9 & -0.6 & 6.3 & 6.3 & 12.9 \\
\hline Belgium & 5.8 & 0.2 & 0.3 & -0.3 & -0.3 & 1.9 & 1.8 & 0.3 & 0.7 & -0.8 & -0.7 & 6.3 & 5.8 & 11.6 \\
\hline Canada & 5.8 & 0.3 & 0.6 & -0.3 & -0.3 & 1.9 & 2.2 & 0.5 & 0.9 & -0.7 & -0.7 & 6.3 & 6.3 & 12.2 \\
\hline Chile & 3.1 & 0.4 & 0.8 & -0.2 & -0.6 & 1.9 & 2.3 & 0.7 & 1.8 & -0.7 & -1.1 & 6.3 & 7.1 & 10.2 \\
\hline Czech Republic & 5.5 & 0.3 & 0.6 & -0.4 & -0.5 & 1.9 & 1.9 & 0.5 & 1.2 & -1.0 & -0.9 & 6.3 & 6.1 & 11.6 \\
\hline Denmark & 6.3 & 0.2 & 0.5 & -0.3 & -0.2 & 1.9 & 2.1 & 0.3 & 0.8 & -0.8 & -0.7 & 6.3 & 5.9 & 12.2 \\
\hline Estonia & 4.3 & 0.2 & 0.4 & -0.4 & -0.5 & 1.9 & 1.6 & 0.3 & 1.1 & -0.8 & -1.1 & 6.3 & 5.8 & 10.1 \\
\hline Finland & 5.2 & 0.2 & 0.5 & -0.4 & -0.3 & 1.9 & 2.0 & 0.3 & 0.7 & -0.7 & -0.7 & 6.3 & 5.9 & 11.2 \\
\hline France & 7.4 & 0.1 & 0.5 & -0.3 & -0.3 & 1.9 & 1.9 & 0.3 & 0.8 & -0.8 & -0.6 & 6.3 & 6.1 & 13.5 \\
\hline Germany & 7.3 & 0.2 & 0.6 & -0.4 & -0.3 & 1.9 & 2.1 & 0.4 & 1.0 & -0.9 & -0.7 & 6.3 & 6.2 & 13.5 \\
\hline Greece & 5.4 & 0.2 & 0.4 & -0.3 & -0.3 & 1.9 & 1.9 & 0.4 & 1.0 & -0.8 & -0.6 & 6.3 & 6.4 & 11.8 \\
\hline Hungary & 4.8 & 0.2 & 0.5 & -0.5 & -0.5 & 1.9 & 1.6 & 0.4 & 1.3 & -1.3 & -1.0 & 6.3 & 5.8 & 10.6 \\
\hline Iceland & 5.8 & 0.0 & 0.5 & -0.3 & -0.2 & 1.9 & 2.0 & 0.1 & 0.7 & -0.6 & -0.7 & 6.3 & 5.9 & 11.7 \\
\hline Israel & 4.0 & 0.2 & 0.4 & -0.3 & -0.2 & 1.9 & 2.0 & 0.5 & 0.9 & -0.7 & -0.7 & 6.3 & 6.4 & 10.4 \\
\hline Ireland & 5.5 & 0.1 & 0.5 & -0.3 & -0.2 & 1.9 & 2.1 & 0.3 & 1.0 & -0.8 & -0.5 & 6.3 & 6.4 & 11.9 \\
\hline Italy & 6.1 & 0.2 & 0.4 & -0.3 & -0.2 & 1.9 & 2.1 & 0.4 & 1.0 & -0.7 & -0.6 & 6.3 & 6.4 & 12.6 \\
\hline Japan & 6.1 & 0.3 & 0.7 & -0.3 & -0.3 & 1.9 & 2.3 & 0.4 & 1.0 & -0.7 & -0.8 & 6.3 & 6.3 & 12.5 \\
\hline Korea & 3.3 & 0.4 & 1.1 & -0.4 & -0.5 & 1.9 & 2.6 & 0.8 & 2.1 & -0.8 & -0.8 & 6.3 & 7.6 & 10.9 \\
\hline Luxembourg & 4.4 & 0.2 & 0.5 & -0.3 & -0.1 & 1.9 & 2.2 & 0.5 & 1.1 & -0.9 & -0.2 & 6.3 & 6.9 & 11.3 \\
\hline Mexico & 2.5 & 0.2 & 0.7 & -0.3 & -0.5 & 1.9 & 2.1 & 0.5 & 2.0 & -0.9 & -1.1 & 6.3 & 6.9 & 9.4 \\
\hline Netherlands & 6.4 & 0.3 & 0.6 & -0.3 & -0.3 & 1.9 & 2.2 & 0.4 & 1.0 & -0.8 & -0.7 & 6.3 & 6.3 & 12.7 \\
\hline New Zealand & 6.4 & 0.3 & 0.5 & -0.3 & -0.3 & 1.9 & 2.1 & 0.5 & 1.0 & -0.6 & -0.9 & 6.3 & 6.3 & 12.7 \\
\hline Norway & 5.1 & 0.2 & 0.4 & -0.3 & -0.4 & 1.9 & 1.9 & 0.4 & 0.8 & -0.7 & -0.7 & 6.3 & 6.1 & 11.2 \\
\hline Poland & 4.1 & 0.3 & 0.7 & -0.5 & -0.5 & 1.9 & 1.9 & 0.5 & 1.7 & -1.3 & -0.9 & 6.3 & 6.4 & 10.5 \\
\hline Portugal & 6.5 & 0.2 & 0.5 & -0.4 & -0.2 & 1.9 & 2.0 & 0.5 & 1.2 & -0.9 & -0.7 & 6.3 & 6.5 & 13.0 \\
\hline Slovak Republic & 5.4 & 0.3 & 0.7 & -0.5 & -0.5 & 1.9 & 1.9 & 0.7 & 1.8 & -1.4 & -0.9 & 6.3 & 6.5 & 11.9 \\
\hline Slovenia & 5.2 & 0.3 & 0.6 & -0.4 & -0.3 & 1.9 & 2.1 & 0.5 & 1.2 & -0.7 & -0.8 & 6.3 & 6.6 & 11.8 \\
\hline Spain & 5.6 & 0.2 & 0.5 & -0.3 & -0.3 & 1.9 & 2.0 & 0.5 & 1.3 & -0.8 & -0.6 & 6.3 & 6.7 & 12.3 \\
\hline Sweden & 6.6 & 0.2 & 0.3 & -0.3 & -0.3 & 1.9 & 1.8 & 0.3 & 0.6 & -0.7 & -0.7 & 6.3 & 5.9 & 12.4 \\
\hline Switzerland & 5.7 & 0.2 & 0.5 & -0.3 & -0.3 & 1.9 & 2.1 & 0.5 & 1.1 & -0.8 & -0.8 & 6.3 & 6.5 & 12.2 \\
\hline & 3.8 & 0.4 & 0.7 & -0.3 & -0.6 & 1.9 & 2.0 & 0.8 & 1.9 & -1.0 & -1.1 & 6.3 & 7.0 & 10.9 \\
\hline United Kingdom & 6.5 & 0.1 & 0.3 & -0.3 & -0.2 & 1.9 & 1.9 & 0.3 & 0.7 & -0.7 & -0.7 & 6.3 & 5.9 & 12.4 \\
\hline United States & 7.1 & 0.2 & 0.5 & -0.3 & -0.3 & 1.9 & 2.0 & 0.3 & 0.7 & -0.6 & -0.7 & 6.3 & 6.1 & 13.2 \\
\hline$O E C D$ average ${ }^{1}$ & 5.5 & 0.2 & 0.5 & -0.4 & -0.3 & 1.9 & 2.0 & 0.4 & 1.1 & -0.8 & -0.8 & 6.3 & 6.3 & 11.8 \\
\hline Brazil & 3.7 & 0.3 & 0.8 & -0.3 & -0.6 & 1.9 & 2.1 & 0.6 & 2.1 & -1.0 & -1.1 & 6.3 & 7.0 & 10.7 \\
\hline $\begin{array}{l}\text { China } \\
\text { China }\end{array}$ & $\begin{array}{l}.1 \\
1.9\end{array}$ & 0.4 & $\begin{array}{l}.0 \\
0.9\end{array}$ & $\begin{array}{l}-0.4 \\
-0.4\end{array}$ & $\begin{array}{l}-0.0 \\
-1.1\end{array}$ & 1.9 & 1.7 & 0.7 & 2.0 & -1.1 & -1.7 & $\begin{array}{l}.3 \\
6.3\end{array}$ & 6.4 & 8.3 \\
\hline India & 1.2 & 0.2 & 0.5 & -0.4 & -1.0 & 1.9 & 1.3 & 0.6 & 1.5 & -1.2 & -1.7 & 6.3 & 5.5 & 6.7 \\
\hline Indonesia & 1.2 & $\begin{array}{l}0.2 \\
0.3\end{array}$ & 0.7 & $\begin{array}{l}-0.4 \\
-0.4\end{array}$ & $\begin{array}{l}-1.0 \\
-0.8\end{array}$ & 1.9 & 1.7 & 0.7 & 2.0 & $\begin{array}{l}-1.2 \\
-1.3\end{array}$ & -1.5 & $\begin{array}{l}.3 \\
6.3\end{array}$ & $\begin{array}{l}.05 \\
6.2\end{array}$ & $\begin{array}{l}.11 \\
7.3\end{array}$ \\
\hline Russia & 3.1 & 0.2 & 0.4 & -0.4 & -0.6 & 1.9 & 1.5 & 0.3 & 0.9 & -1.0 & -1.0 & 6.3 & 5.5 & 8.6 \\
\hline South Africa & 3.2 & 0.1 & 0.4 & -0.5 & -0.6 & 1.9 & 1.4 & 0.3 & 1.1 & -1.4 & -1.2 & 6.3 & 5.2 & 8.4 \\
\hline Non-OECD average ${ }^{1}$ & 2.4 & 0.2 & 0.6 & -0.4 & -0.8 & 1.9 & 1.6 & 0.5 & 1.6 & -1.2 & -1.4 & 6.3 & 5.9 & 8.3 \\
\hline Total average ${ }^{1}$ & 5.0 & 0.2 & 0.5 & -0.4 & -0.4 & 1.9 & 2.0 & 0.5 & 1.2 & -0.9 & -0.8 & 6.3 & 6.3 & 11.3 \\
\hline
\end{tabular}


Table A5.3. Breakdown of the projections of public health care expenditure for each driver

Cost-containment scenario

\begin{tabular}{|c|c|c|c|c|c|c|c|c|c|c|c|c|c|c|}
\hline & $\begin{array}{c}\text { Health } \\
\text { expenditure } \\
\text { as a } \% \text { of } \\
\text { GDP }\end{array}$ & $\begin{array}{l}\text { Death- } \\
\text { related } \\
\text { costs }\end{array}$ & $\begin{array}{l}\text { Pure age } \\
\text { effect } \\
\text { (surivors) }\end{array}$ & $\begin{array}{l}\text { Adjustment } \\
\text { for healthy } \\
\text { ageing }\end{array}$ & $\begin{array}{l}\text { Income } \\
\text { effect }\end{array}$ & $\begin{array}{l}\text { Non-ageing } \\
\text { residual } \\
\text { effect }\end{array}$ & Total & $\begin{array}{l}\text { Death- } \\
\text { related } \\
\text { costs }\end{array}$ & $\begin{array}{c}\begin{array}{c}\text { Pure age } \\
\text { effect } \\
\text { (surivors) }\end{array}\end{array}$ & $\begin{array}{l}\text { Adjustment } \\
\text { for healthy } \\
\text { ageing }\end{array}$ & $\begin{array}{l}\text { Income } \\
\text { effect }\end{array}$ & $\begin{array}{l}\text { Non-ageing } \\
\text { residual } \\
\text { effect }\end{array}$ & Total & \begin{tabular}{|c|} 
Health \\
expenditure \\
as a \% of \\
GDP
\end{tabular} \\
\hline & $\begin{array}{c}\text { Average } \\
2006-2010\end{array}$ & \multicolumn{6}{|c|}{ Increase in \% points of GDP $2010-2030$} & \multicolumn{6}{|c|}{ Increase in \% points of GDP 2010-2060 } & 2060 \\
\hline Australia & 5.6 & 0.2 & 0.5 & -0.3 & -0.4 & 1.5 & 1.5 & 0.5 & 1.0 & -0.6 & -0.8 & 2.5 & 2.5 & 8.1 \\
\hline Austria & 6.6 & 0.2 & 0.5 & -0.3 & -0.2 & 1.5 & 1.7 & 0.4 & 1.0 & -0.9 & -0.6 & 2.5 & 2.4 & 9.1 \\
\hline Belgium & 5.8 & 0.2 & 0.3 & -0.3 & -0.3 & 1.5 & 1.4 & 0.3 & 0.7 & -0.8 & -0.7 & 2.5 & 1.9 & 7.7 \\
\hline Canada & 5.8 & 0.3 & 0.6 & -0.3 & -0.3 & 1.5 & 1.8 & 0.5 & 0.9 & -0.7 & -0.7 & 2.5 & 2.5 & 8.3 \\
\hline Chile & 3.1 & 0.4 & 0.8 & -0.2 & -0.6 & 1.5 & 1.8 & 0.7 & 1.8 & -0.7 & -1.1 & 2.5 & 3.2 & 6.3 \\
\hline Czech Republic & 5.5 & 0.3 & 0.6 & -0.4 & -0.5 & 1.5 & 1.4 & 0.5 & 1.2 & -1.0 & -0.9 & 2.5 & 2.2 & 7.7 \\
\hline Denmark & 6.3 & 0.2 & 0.5 & -0.3 & -0.2 & 1.5 & 1.6 & 0.3 & 0.8 & -0.8 & -0.7 & 2.5 & 2.0 & 8.3 \\
\hline Estonia & 4.3 & 0.2 & 0.4 & -0.4 & -0.5 & 1.5 & 1.1 & 0.3 & 1.1 & -0.8 & -1.1 & 2.5 & 2.0 & 6.2 \\
\hline Finland & 5.2 & 0.2 & 0.5 & -0.4 & -0.3 & 1.5 & 1.5 & 0.3 & 0.7 & -0.7 & -0.7 & 2.5 & 2.0 & 7.3 \\
\hline France & 7.4 & 0.1 & 0.5 & -0.3 & -0.3 & 1.5 & 1.4 & 0.3 & 0.8 & -0.8 & -0.6 & 2.5 & 2.2 & 9.6 \\
\hline Germany & $\begin{array}{l}7.3 \\
54\end{array}$ & 0.2 & 0.6 & -0.4 & $\begin{array}{l}-0.3 \\
-0.3\end{array}$ & $\begin{array}{l}1.5 \\
15\end{array}$ & $\begin{array}{l}1.6 \\
14\end{array}$ & 0.4 & 1.0 & $\begin{array}{l}-0.9 \\
-0.8\end{array}$ & -0.7 & $\begin{array}{l}2.5 \\
25\end{array}$ & $\begin{array}{l}2.3 \\
25\end{array}$ & 9.6 \\
\hline Greece & 5.4 & 0.2 & 0.4 & -0.3 & -0.3 & 1.5 & 1.4 & 0.4 & 1.0 & -0.8 & -0.6 & 2.5 & 2.5 & 7.9 \\
\hline Hungary & 4.8 & 0.2 & 0.5 & -0.5 & -0.5 & 1.5 & 1.2 & 0.4 & 1.3 & -1.3 & -1.0 & 2.5 & 1.9 & 6.7 \\
\hline Iceland & 5.8 & 0.0 & 0.5 & -0.3 & -0.2 & 1.5 & 1.5 & 0.1 & 0.7 & -0.6 & -0.7 & 2.5 & 2.0 & 7.8 \\
\hline Israel & 4.0 & 0.2 & 0.4 & -0.3 & -0.2 & 1.5 & 1.5 & 0.5 & 0.9 & -0.7 & -0.7 & 2.5 & 2.5 & 6.6 \\
\hline Ireland & 5.5 & 0.1 & 0.5 & -0.3 & -0.2 & 1.5 & 1.6 & 0.3 & 1.0 & -0.8 & -0.5 & 2.5 & 2.5 & 8.0 \\
\hline 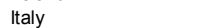 & & 0.2 & 0.4 & -0.3 & -0.2 & 1.5 & 1.6 & 0.4 & 1.0 & -0.7 & & & 2.6 & 8.7 \\
\hline Japan & 6.1 & 0.3 & 0.7 & -0.3 & -0.3 & 1.5 & 1.8 & 0.4 & 1.0 & -0.7 & -0.8 & 2.5 & 2.5 & 8.6 \\
\hline Korea & 3.3 & 0.4 & 1.1 & -0.4 & -0.5 & 1.5 & 2.1 & 0.8 & 2.1 & -0.8 & -0.8 & 2.5 & 3.7 & 7.0 \\
\hline Luxembourg & 4.4 & 0.2 & 0.5 & -0.3 & -0.1 & 1.5 & 1.7 & 0.5 & 1.1 & -0.9 & -0.2 & 2.5 & 3.0 & 7.4 \\
\hline Mexico & 2.5 & 0.2 & 0.7 & -0.3 & -0.5 & 1.5 & 1.6 & 0.5 & 2.0 & -0.9 & -1.1 & 2.5 & 3.0 & 5.5 \\
\hline Netherlands & 6.4 & 0.3 & 0.6 & -0.3 & -0.3 & 1.5 & 1.8 & 0.4 & 1.0 & -0.8 & -0.7 & 2.5 & 2.4 & 8.8 \\
\hline New Zealand & 6.4 & 0.3 & 0.5 & -0.3 & -0.3 & 1.5 & 1.6 & 0.5 & 1.0 & -0.6 & -0.9 & 2.5 & 2.4 & 8.8 \\
\hline Norway & 5.1 & 0.2 & 0.4 & -0.3 & -0.4 & 1.5 & 1.4 & 0.4 & 0.8 & -0.7 & -0.7 & 2.5 & 2.2 & 7.3 \\
\hline Poland & 4.1 & 0.3 & 0.7 & -0.5 & -0.5 & 1.5 & 1.4 & 0.5 & 1.7 & -1.3 & -0.9 & 2.5 & 2.6 & 6.7 \\
\hline Portugal & 6.5 & 0.2 & 0.5 & -0.4 & -0.2 & 1.5 & 1.6 & 0.5 & 1.2 & -0.9 & -0.7 & 2.5 & 2.6 & 9.1 \\
\hline Slovak Republic & 5.4 & 0.3 & 0.7 & -0.5 & -0.5 & 1.5 & 1.5 & 0.7 & 1.8 & -1.4 & -0.9 & 2.5 & 2.6 & 8.0 \\
\hline Slovenia & 5.2 & 0.3 & 0.6 & -0.4 & -0.3 & 1.5 & 1.7 & 0.5 & 1.2 & -0.7 & -0.8 & 2.5 & 2.7 & 7.9 \\
\hline Spain & 5.6 & 0.2 & 0.5 & -0.3 & -0.3 & 1.5 & 1.6 & 0.5 & 1.3 & -0.8 & -0.6 & 2.5 & 2.8 & 8.5 \\
\hline Sweden & 6.6 & 0.2 & 0.3 & -0.3 & -0.3 & 1.5 & 1.3 & 0.3 & 0.6 & -0.7 & -0.7 & 2.5 & 2.0 & 8.6 \\
\hline Switzerland & 5.7 & 0.2 & 0.5 & -0.3 & -0.3 & 1.5 & 1.6 & 0.5 & 1.1 & -0.8 & -0.8 & 2.5 & 2.6 & 8.3 \\
\hline & 3.8 & 0.4 & 0.7 & -0.3 & -0.6 & 1.5 & 1.5 & 0.8 & 1.9 & -1.0 & -1.1 & 2.5 & 3.1 & 7.0 \\
\hline United Kingdom & 6.5 & 0.1 & 0.3 & -0.3 & -0.2 & 1.5 & 1.4 & 0.3 & 0.7 & -0.7 & -0.7 & 2.5 & 2.0 & 8.5 \\
\hline United States & 7.1 & 0.2 & 0.5 & -0.3 & -0.3 & 1.5 & 1.5 & 0.3 & 0.7 & -0.6 & -0.7 & 2.5 & 2.2 & 9.3 \\
\hline$O E C D$ average ${ }^{1}$ & 5.5 & 0.2 & 0.5 & -0.4 & -0.3 & 1.5 & 1.6 & 0.4 & 1.1 & -0.8 & -0.8 & 2.5 & 2.5 & 7.9 \\
\hline Brazil & 3.7 & 0.3 & 0.8 & -0.3 & -0.6 & 1.5 & 1.6 & 0.6 & 2.1 & -1.0 & -1.1 & 2.5 & 3.1 & 6.8 \\
\hline $\begin{array}{l}\text { China } \\
\text { Chat }\end{array}$ & $\begin{array}{l}.1 .9 \\
1.9\end{array}$ & 0.4 & 0.9 & -0.4 & -1.1 & 1.5 & 1.3 & 0.7 & 2.0 & -1.1 & -1.7 & 2.5 & 2.5 & 4.4 \\
\hline India & 1.2 & 0.2 & 0.5 & -0.4 & -1.0 & 1.5 & 0.8 & 0.6 & 1.5 & -1.2 & -1.7 & 2.5 & 1.6 & 2.8 \\
\hline Indonesia & 1.2 & 0.3 & 0.7 & -0.4 & -0.8 & 1.5 & 1.3 & 0.7 & 2.0 & -1.3 & -1.5 & 2.5 & 2.3 & 3.5 \\
\hline Russia & 3.1 & 0.2 & 0.4 & -0.4 & -0.6 & 1.5 & 1.0 & 0.3 & 0.9 & -1.0 & -1.0 & 2.5 & 1.6 & 4.7 \\
\hline South Africa & 3.2 & 0.1 & 0.4 & -0.5 & -0.6 & 1.5 & 0.9 & 0.3 & 1.1 & -1.4 & -1.2 & 2.5 & 1.3 & 4.5 \\
\hline Non-OECD average ${ }^{1}$ & 2.4 & 0.2 & 0.6 & -0.4 & -0.8 & 1.5 & 1.2 & 0.5 & 1.6 & -1.2 & -1.4 & 2.5 & 2.1 & 4.4 \\
\hline Total average ${ }^{1}$ & 5.0 & 0.2 & 0.5 & -0.4 & -0.4 & 1.5 & 1.5 & 0.5 & 1.2 & -0.9 & -0.8 & 2.5 & 2.4 & 7.4 \\
\hline
\end{tabular}


Table A5.4. Breakdown of the projections of public health care expenditure for each driver

ECO/WKP(2013)40

Sensitivity analysis: income elasticity $=0.6$

\begin{tabular}{|c|c|c|c|c|c|c|c|c|c|c|c|c|c|c|}
\hline & $\begin{array}{c}\text { Health } \\
\text { expenditure } \\
\text { as a \% of } \\
\text { GDP }\end{array}$ & $\begin{array}{l}\text { Death- } \\
\text { related } \\
\text { costs }\end{array}$ & $\begin{array}{l}\begin{array}{c}\text { Pure age } \\
\text { effect } \\
\text { (surivors) }\end{array}\end{array}$ & $\begin{array}{l}\text { Adjustment } \\
\text { for healthy } \\
\text { ageing }\end{array}$ & $\begin{array}{l}\text { Income } \\
\text { effect }\end{array}$ & $\begin{array}{c}\text { Non-ageing } \\
\text { residual } \\
\text { effect }\end{array}$ & Total & $\begin{array}{l}\text { Death- } \\
\text { related } \\
\text { costs }\end{array}$ & 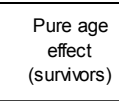 & $\begin{array}{l}\text { Adjustment } \\
\text { for healthy } \\
\text { ageing }\end{array}$ & $\begin{array}{l}\text { Income } \\
\text { effect }\end{array}$ & $\begin{array}{c}\text { Non-ageing } \\
\text { residual } \\
\text { effect }\end{array}$ & Total & \begin{tabular}{|c|c} 
Health \\
expenditure \\
as a \% of \\
GDP
\end{tabular} \\
\hline & $\begin{array}{c}\text { Average } \\
2006-2010\end{array}$ & \multicolumn{6}{|c|}{ Increase in \% points of GDP 2010-2030 } & \multicolumn{6}{|c|}{ Increase in \% points of GDP 2010-2060 } & 2060 \\
\hline Australia & 5.6 & 0.2 & 0.5 & -0.3 & -0.7 & 1.5 & 1.2 & 0.5 & 1.0 & -0.6 & -1.5 & 2.5 & 1.8 & 7.4 \\
\hline Austria & 6.6 & 0.2 & & -0.3 & -0.5 & 1.5 & 1.4 & 0.4 & 1.0 & -0.9 & -1.1 & 2.5 & 1.9 & 8.5 \\
\hline Belgium & 5.8 & 0.2 & 0.3 & -0.3 & -0.5 & 1.5 & 1.1 & 0.3 & 0.7 & -0.8 & -1.3 & 2.5 & 1.3 & 7.1 \\
\hline Canada & 5.8 & 0.3 & 0.6 & -0.3 & -0.5 & 1.5 & 1.5 & 0.5 & 0.9 & -0.7 & -1.4 & 2.5 & 1.8 & 7.7 \\
\hline Chile & 3.1 & 0.4 & 0.8 & -0.2 & -1.1 & 1.5 & 1.3 & 0.7 & 1.8 & -0.7 & -1.9 & 2.5 & 2.4 & 5.4 \\
\hline Czech Republic & 5.5 & 0.3 & 0.6 & -0.4 & -0.9 & 1.5 & 1.0 & 0.5 & 1.2 & -1.0 & -1.7 & 2.5 & 1.5 & 7.0 \\
\hline Denmark & 6.3 & 0.2 & 0.5 & -0.3 & -0.4 & 1.5 & 1.5 & 0.3 & 0.8 & -0.8 & -1.3 & 2.5 & 1.4 & 7.7 \\
\hline Estonia & 4.3 & 0.2 & 0.4 & -0.4 & -1.0 & 1.5 & 0.6 & 0.3 & 1.1 & -0.8 & -2.0 & 2.5 & 1.1 & 5.4 \\
\hline Finland & 5.2 & 0.2 & 0.5 & -0.4 & -0.6 & 1.5 & 1.2 & 0.3 & 0.7 & -0.7 & -1.3 & 2.5 & 1.4 & 6.7 \\
\hline France & 7.4 & 0.1 & 0.5 & -0.3 & -0.6 & 1.5 & 1.2 & 0.3 & 0.8 & -0.8 & -1.1 & 2.5 & 1.6 & 9.0 \\
\hline Germany & 7.3 & 0.2 & 0.6 & -0.4 & -0.6 & 1.5 & 1.4 & 0.4 & 1.0 & -0.9 & -1.3 & 2.5 & 1.8 & 9.0 \\
\hline & 5.4 & 0.2 & 0.4 & -0.3 & -0.6 & 1.5 & 1.2 & 0.4 & 1.0 & -0.8 & & & 2.0 & 7.3 \\
\hline Hungary & 4.8 & 0.2 & 0.5 & -0.5 & -0.9 & 1.5 & 0.7 & 0.4 & 1.3 & -1.3 & -1.8 & 2. & 1.2 & 5.9 \\
\hline Iceland & 5.8 & 0.0 & 0.5 & -0.3 & -0.4 & 1.5 & 1.3 & 0.1 & 0.7 & -0.6 & -1.3 & 2 & 1.4 & 7.2 \\
\hline Israel & 4.0 & 0.2 & 0.4 & -0.3 & -0.5 & 1.5 & 1.3 & 0.5 & 0.9 & -0.7 & -1.2 & 2.5 & 2.0 & 6.0 \\
\hline Ireland & 5.5 & 0.1 & 0.5 & -0.3 & -0.4 & 1.5 & 1.4 & 0.3 & 1.0 & -0.8 & -0.9 & 2.5 & 2.1 & 7.6 \\
\hline Italy & 6.1 & 0.2 & 0.4 & -0.3 & -0.3 & 1.5 & 1.4 & 0.4 & 1.0 & -0.7 & -1.1 & 2.5 & 2.1 & 8.2 \\
\hline Japan & 6.1 & 0.3 & 0.7 & -0.3 & -0.5 & 1.5 & 1.5 & 0.4 & 1.0 & -0.7 & -1.4 & 2.5 & 1.8 & 7.9 \\
\hline Korea & 3.3 & 0.4 & 1.1 & -0.4 & -0.9 & 1.5 & 1.7 & 0.8 & 2.1 & -0.8 & -1.5 & 2.5 & 3.0 & 6.3 \\
\hline Luxembourg & 4.4 & 0.2 & 0.5 & -0.3 & -0.3 & 1.5 & 1.6 & 0.5 & 1.1 & -0.9 & -0.3 & 2.5 & 2.9 & 7.3 \\
\hline Mexico & 2.5 & 0.2 & 0.7 & -0.3 & -0.9 & 1.5 & 1.2 & 0.5 & 2.0 & -0.9 & -1.9 & 2.5 & 2.2 & 4.7 \\
\hline Netherlands & 6.4 & 0.3 & 0.6 & -0.3 & -0.6 & 1.5 & 1.5 & 0.4 & 1.0 & -0.8 & -1.3 & 2.5 & 1.8 & 8.2 \\
\hline New Zealand & 6.4 & 0.3 & 0.5 & -0.3 & -0.6 & 1.5 & 1.3 & 0.5 & 1.0 & -0.6 & -1.6 & 2.5 & 1.7 & 8.1 \\
\hline Norway & 5.1 & 0.2 & 0.4 & -0.3 & -0.7 & 1.5 & 1.1 & 0.4 & 0.8 & -0.7 & -1.4 & 2.5 & 1.6 & 6.7 \\
\hline Poland & 4.1 & 0.3 & 0.7 & -0.5 & -0.9 & 1.5 & 1.0 & 0.5 & 1.7 & -1.3 & -1.6 & 2.5 & 1.9 & 6.0 \\
\hline Portugal & 6.5 & 0.2 & 0.5 & -0.4 & -0.5 & 1.5 & 1.3 & 0.5 & 1.2 & -0.9 & -1.2 & 2.5 & 2.0 & 8.5 \\
\hline Slovak Republic & 5.4 & 0.3 & 0.7 & -0.5 & -1.0 & 1.5 & 1.0 & 0.7 & 1.8 & -1.4 & -1.7 & 2.5 & 1.9 & 7.3 \\
\hline Slovenia & 5.2 & 0.3 & 0.6 & -0.4 & -0.6 & 1.5 & 1.4 & 0.5 & 1.2 & -0.7 & -1.4 & 2.5 & 2.1 & 7.3 \\
\hline Spain & 5.6 & 0.2 & 0.5 & -0.3 & -0.6 & 1.5 & 1.3 & 0.5 & 1.3 & -0.8 & -1.2 & 2.5 & 2.3 & 7.9 \\
\hline Sweden & 6.6 & 0.2 & 0.3 & -0.3 & -0.7 & 1.5 & 1.0 & 0.3 & 0.6 & -0.7 & -1.4 & 2.5 & 1.3 & 7.9 \\
\hline Switzerland & 5.7 & 0.2 & 0.5 & -0.3 & -0.5 & 1.5 & 1.4 & 0.5 & 1.1 & -0.8 & -1.4 & 2.5 & 1.9 & 7.6 \\
\hline & 3.8 & 0.4 & 0.7 & -0.3 & -1.2 & 1.5 & 1.0 & 0.8 & 1.9 & -1.0 & -1.9 & 2.5 & 2.3 & 6.1 \\
\hline United Kir & 6.5 & 0.1 & 0.3 & -0.3 & -0.5 & 1.5 & 1.2 & 0.3 & 0.7 & -0.7 & -1.3 & 2. & 1.4 & 7.9 \\
\hline United States & 7.1 & 0.2 & 0.5 & -0.3 & -0.5 & 1.5 & 1.3 & 0.3 & 0.7 & -0.6 & -1.3 & 2.5 & 1.7 & 8.7 \\
\hline$O E C D$ average ${ }^{1}$ & 5.5 & 0.2 & 0.5 & -0.4 & -0.6 & 1.5 & 1.2 & 0.4 & 1.1 & -0.8 & -1.4 & 2.5 & 1.8 & 7.3 \\
\hline Brazil & 3.7 & 0.3 & 0.8 & -0.3 & -1.2 & 1.5 & 1.1 & 0.6 & 2.1 & -1.0 & -2.0 & 2.5 & 2.2 & 5.9 \\
\hline & 1.9 & 0.4 & & -0.4 & -2.0 & 1.5 & 0.4 & 0.7 & 2.0 & -1.1 & -2.8 & 2.5 & 1.4 & 3.3 \\
\hline Ind & 1.2 & 0.2 & 0 & -0.4 & -1 & 1.5 & 0.1 & 0.6 & 1. & -1.2 & -2.8 & 2.5 & 0.5 & 1.7 \\
\hline & 1.2 & 0.3 & 0. & -0.4 & -1.5 & 1.5 & 0.6 & 0.7 & 2.0 & -1.3 & -2.6 & 2.5 & 1.2 & 2.4 \\
\hline Russia & 3.1 & 0.2 & 0.4 & -0.4 & -1.1 & 1.5 & 0.5 & 0.3 & 0.9 & -1.0 & -1.8 & 2.5 & 0.8 & 3.9 \\
\hline South Africa & 3.2 & 0.1 & 0.4 & -0.5 & -1.1 & 1.5 & 0.4 & 0.3 & 1.1 & -1.4 & -2.0 & 2.5 & 0.4 & 3.6 \\
\hline Non-OECD average ${ }^{1}$ & 2.4 & 0.2 & 0.6 & -0.4 & -1.4 & 1.5 & 0.5 & 0.5 & 1.6 & -1.2 & -2.3 & 2.5 & 1.1 & 3.5 \\
\hline Total average $^{1}$ & 5.0 & 0.2 & 0.5 & -0.4 & -0.8 & 1.5 & 1.1 & 0.5 & 1.2 & -0.9 & -1.5 & 2.5 & 1.7 & 6.7 \\
\hline
\end{tabular}


Table A5.5. Breakdown of the projections of public health care expenditure for each driver

Sensitivity analysis: income elasticity $=1$

\begin{tabular}{|c|c|c|c|c|c|c|c|c|c|c|c|c|c|c|}
\hline & $\begin{array}{c}\text { Health } \\
\text { expenditure } \\
\text { as a \% of } \\
\text { GDP }\end{array}$ & $\begin{array}{l}\text { Death- } \\
\text { related } \\
\text { costs }\end{array}$ & $\begin{array}{l}\begin{array}{c}\text { Pure age } \\
\text { effect } \\
\text { (surivors) }\end{array}\end{array}$ & $\begin{array}{l}\text { Adjustment } \\
\text { for healthy } \\
\text { ageing }\end{array}$ & $\begin{array}{l}\text { Income } \\
\text { effect }\end{array}$ & $\begin{array}{c}\text { Non-ageing } \\
\text { residual } \\
\text { effect }\end{array}$ & Total & $\begin{array}{l}\text { Death- } \\
\text { related } \\
\text { costs }\end{array}$ & 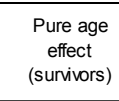 & $\begin{array}{l}\text { Adjustment } \\
\text { for healthy } \\
\text { ageing }\end{array}$ & $\begin{array}{l}\text { Income } \\
\text { effect }\end{array}$ & $\begin{array}{c}\text { Non-ageing } \\
\text { residual } \\
\text { effect }\end{array}$ & Total & \begin{tabular}{|c|c} 
Health \\
expenditure \\
as a \% of \\
GDP
\end{tabular} \\
\hline & $\begin{array}{c}\text { Average } \\
2006-2010\end{array}$ & \multicolumn{6}{|c|}{ Increase in \% points of GDP $2010-2030$} & \multicolumn{6}{|c|}{ Increase in \% points of GDP 2010-2060 } & 2060 \\
\hline Australia & 5.6 & 0.2 & 0.5 & -0.3 & 0.0 & 1.5 & 1.9 & 0.5 & 1.0 & -0.6 & 0.0 & 2.5 & 3.2 & 8.9 \\
\hline Austria & 6.6 & 0.2 & & -0.3 & 0.0 & 1.5 & 1.9 & 0.4 & 1.0 & -0.9 & 0.0 & 2.5 & 3.0 & 9.6 \\
\hline Belgium & 5.8 & 0.2 & 0.3 & -0.3 & 0.0 & 1.5 & 1.6 & 0.3 & 0.7 & -0.8 & 0.0 & 2.5 & 2.7 & 8.4 \\
\hline Canada & 5.8 & 0.3 & 0.6 & -0.3 & 0.0 & 1.5 & 2.0 & 0.5 & 0.9 & -0.7 & 0.0 & 2.5 & 3.2 & 9.0 \\
\hline Chile & 3.1 & 0.4 & 0.8 & -0.2 & 0.0 & 1.5 & 2.4 & 0.7 & 1.8 & -0.7 & 0.0 & 2.5 & 4.3 & 7.4 \\
\hline Czech Republic & 5.5 & 0.3 & 0.6 & -0.4 & 0.0 & 1.5 & 1.9 & 0.5 & 1.2 & -1.0 & 0.0 & 2.5 & 3.2 & 8.7 \\
\hline Denmark & 6.3 & 0.2 & 0.5 & -0.3 & 0.0 & 1.5 & 1.8 & 0.3 & 0.8 & -0.8 & 0.0 & 2.5 & 2.7 & 9.0 \\
\hline Estonia & 4.3 & 0.2 & 0.4 & -0.4 & 0.0 & 1.5 & 1.7 & 0.3 & 1.1 & -0.8 & 0.0 & 2.5 & 3.1 & 7.3 \\
\hline Finland & 5.2 & 0.2 & 0.5 & -0.4 & 0.0 & 1.5 & 1.8 & 0.3 & 0.7 & -0.7 & 0.0 & 2.5 & 2.8 & 8.0 \\
\hline France & 7.4 & 0.1 & 0.5 & -0.3 & 0.0 & 1.5 & 1.7 & 0.3 & 0.8 & -0.8 & 0.0 & 2.5 & 2.8 & 10.2 \\
\hline Germany & 7.3 & 0.2 & 0.6 & -0.4 & 0.0 & 1.5 & 1.9 & 0.4 & 1.0 & -0.9 & 0.0 & 2.5 & 3.0 & 10.3 \\
\hline & 5.4 & 0.2 & 0.4 & -0.3 & 0.0 & 1.5 & 1.7 & 0.4 & 1.0 & -0.8 & 0.0 & & 3.1 & 8.5 \\
\hline Hungary & 4.8 & 0.2 & 0.5 & -0.5 & 0.0 & 1.5 & 1.7 & 0.4 & 1.3 & -1.3 & 0.0 & 2. & 2.9 & 7.7 \\
\hline Iceland & 5.8 & 0.0 & 0.5 & -0.3 & 0.0 & 1.5 & 1.7 & 0.1 & 0.7 & -0.6 & 0.0 & 2. & 2.7 & 8.5 \\
\hline Israel & 4.0 & 0.2 & 0.4 & -0.3 & 0.0 & 1.5 & 1.8 & 0.5 & 0.9 & -0.7 & 0.0 & 2.5 & 3.2 & 7.2 \\
\hline Ireland & 5.5 & 0.1 & 0.5 & -0.3 & 0.0 & 1.5 & 1.8 & 0.3 & 1.0 & -0.8 & 0.0 & 2.5 & 3.0 & 8.5 \\
\hline Italy & 6.1 & 0.2 & 0.4 & -0.3 & 0.0 & 1.5 & 1.8 & 0.4 & 1.0 & -0.7 & 0.0 & 2.5 & 3.1 & 9.3 \\
\hline Japan & 6.1 & 0.3 & 0.7 & -0.3 & 0.0 & 1.5 & 2.1 & 0.4 & 1.0 & -0.7 & 0.0 & 2.5 & 3.2 & 9.3 \\
\hline Korea & 3.3 & 0.4 & 1.1 & -0.4 & 0.0 & 1.5 & 2.6 & 0.8 & 2.1 & -0.8 & 0.0 & 2.5 & 4.5 & 7.8 \\
\hline Luxembourg & 4.4 & 0.2 & 0.5 & -0.3 & 0.0 & 1.5 & 1.8 & 0.5 & 1.1 & -0.9 & 0.0 & 2.5 & 3.2 & 7.6 \\
\hline Mexico & 2.5 & 0.2 & 0.7 & -0.3 & 0.0 & 1.5 & 2.1 & 0.5 & 2.0 & -0.9 & 0.0 & 2.5 & 4.1 & 6.6 \\
\hline Netherlands & 6.4 & 0.3 & 0.6 & -0.3 & 0.0 & 1.5 & 2.0 & 0.4 & 1.0 & -0.8 & 0.0 & 2.5 & 3.1 & 9.5 \\
\hline New Zealand & 6.4 & 0.3 & 0.5 & -0.3 & 0.0 & 1.5 & 2.0 & 0.5 & 1.0 & -0.6 & 0.0 & 2.5 & 3.3 & 9.7 \\
\hline Norway & 5.1 & 0.2 & 0.4 & -0.3 & 0.0 & 1.5 & 1.8 & 0.4 & 0.8 & -0.7 & 0.0 & 2.5 & 3.0 & 8.0 \\
\hline Poland & 4.1 & 0.3 & 0.7 & -0.5 & 0.0 & 1.5 & 1.9 & 0.5 & 1.7 & -1.3 & 0.0 & 2.5 & 3.4 & 7.5 \\
\hline Portugal & 6.5 & 0.2 & 0.5 & -0.4 & 0.0 & 1.5 & 1.8 & 0.5 & 1.2 & -0.9 & 0.0 & 2.5 & 3.3 & 9.7 \\
\hline Slovak Republic & 5.4 & 0.3 & 0.7 & -0.5 & 0.0 & 1.5 & 2.0 & 0.7 & 1.8 & -1.4 & 0.0 & 2.5 & 3.6 & 9.0 \\
\hline Slovenia & 5.2 & 0.3 & 0.6 & -0.4 & 0.0 & 1.5 & 2.0 & 0.5 & 1.2 & -0.7 & 0.0 & 2.5 & 3.5 & 8.7 \\
\hline Spain & 5.6 & 0.2 & 0.5 & -0.3 & 0.0 & 1.5 & 1.9 & 0.5 & 1.3 & -0.8 & 0.0 & 2.5 & 3.5 & 9.1 \\
\hline Sweden & 6.6 & 0.2 & 0.3 & -0.3 & 0.0 & 1.5 & 1.6 & 0.3 & 0.6 & -0.7 & 0.0 & 2.5 & 2.7 & 9.3 \\
\hline Switzerland & 5.7 & 0.2 & 0.5 & -0.3 & 0.0 & 1.5 & 1.9 & 0.5 & 1.1 & -0.8 & 0.0 & 2.5 & 3.3 & 9.0 \\
\hline & 3.8 & 0.4 & 0.7 & -0.3 & 0.0 & 1.5 & 2.2 & 0.8 & 1.9 & -1.0 & 0.0 & 2.5 & 4.2 & 8.0 \\
\hline United Kir & 6.5 & 0.1 & 0.3 & -0.3 & 0.0 & 1.5 & 1.7 & 0.3 & 0.7 & -0.7 & 0.0 & 2. & 2.7 & 9.2 \\
\hline United States & 7.1 & 0.2 & 0.5 & -0.3 & 0.0 & 1.5 & 1.8 & 0.3 & 0.7 & -0.6 & 0.0 & 2.5 & 2.9 & 10.0 \\
\hline$O E C D$ average ${ }^{1}$ & 5.5 & 0.2 & 0.5 & -0.4 & 0.0 & 1.5 & 1.9 & 0.4 & 1.1 & -0.8 & 0.0 & 2.5 & 3.2 & 8.7 \\
\hline Brazil & 3.7 & 0.3 & 0.8 & -0.3 & 0.0 & 1.5 & 2.2 & 0.6 & 2.1 & -1.0 & 0.0 & 2.5 & 4.2 & 7.9 \\
\hline & 1.9 & 0.4 & & -0.4 & 0.0 & 1.5 & 2.4 & 0.7 & 2.0 & -1.1 & 0.0 & 2.5 & 4.2 & 6.1 \\
\hline Ind & 1.2 & 0.2 & 0 & -0.4 & 0 & 1.5 & 1.8 & 0.6 & 1. & -1.2 & 0.0 & 2.5 & 3.3 & 4.5 \\
\hline & 1.2 & 0.3 & 0.7 & -0.4 & 0 & 1.5 & 2.1 & 0.7 & 2.0 & -1.3 & 0.0 & 2.5 & 3.8 & 5.0 \\
\hline Russia & 3.1 & 0.2 & 0.4 & -0.4 & 0.0 & 1.5 & 1.6 & 0.3 & 0.9 & -1.0 & 0.0 & 2.5 & 2.6 & 5.8 \\
\hline South Africa & 3.2 & 0.1 & 0.4 & -0.5 & 0.0 & 1.5 & 1.5 & 0.3 & 1.1 & -1.4 & 0.0 & 2.5 & 2.4 & 5.6 \\
\hline Non-OECD average ${ }^{1}$ & 2.4 & 0.2 & 0.6 & -0.4 & 0.0 & 1.5 & 1.9 & 0.5 & 1.6 & -1.2 & 0.0 & 2.5 & 3.4 & 5.8 \\
\hline Total average ${ }^{1}$ & 5.0 & 0.2 & 0.5 & -0.4 & 0.0 & 1.5 & 1.9 & 0.5 & 1.2 & -0.9 & 0.0 & 2.5 & 3.3 & 8.2 \\
\hline
\end{tabular}


Table A5.6. Breakdown of the projections of public health care expenditure for each driver

ECO/WKP(2013)40

Country-specific residuals converging to zero

\begin{tabular}{|c|c|c|c|c|c|c|c|c|c|c|c|c|c|c|}
\hline & $\begin{array}{c}\text { Health } \\
\text { expenditure } \\
\text { as a } \% \text { of } \\
\text { GDP }\end{array}$ & $\begin{array}{l}\text { Death- } \\
\text { related } \\
\text { costs }\end{array}$ & $\begin{array}{l}\text { Pure age } \\
\text { effect } \\
\text { (surivors) }\end{array}$ & $\begin{array}{l}\text { Adjustment } \\
\text { for healthy } \\
\text { ageing }\end{array}$ & $\begin{array}{c}\text { Income } \\
\text { effect }\end{array}$ & $\begin{array}{c}\text { Non-ageing } \\
\text { residual } \\
\text { effect }\end{array}$ & Total & $\begin{array}{l}\text { Death- } \\
\text { related } \\
\text { costs }\end{array}$ & $\begin{array}{l}\text { Pure age } \\
\text { effect } \\
\text { (survivors) }\end{array}$ & $\begin{array}{l}\text { Adjustment } \\
\text { for healthy } \\
\text { ageing }\end{array}$ & $\begin{array}{l}\text { Income } \\
\text { effect }\end{array}$ & $\begin{array}{c}\text { Non-ageing } \\
\text { residual } \\
\text { effect }\end{array}$ & Total & \begin{tabular}{|c|} 
Health \\
expenditure \\
as a $\%$ of \\
GDP
\end{tabular} \\
\hline & $\begin{array}{c}\text { Average } \\
2006-2011\end{array}$ & \multicolumn{6}{|c|}{ Increase in \% points of GDP 2010-2030 } & \multicolumn{6}{|c|}{ Increase in \% points of GDP 2010-2060 } & 2060 \\
\hline Australia & 5.6 & 0.2 & 0.5 & -0.3 & -0.4 & 6.2 & 6.2 & 0.5 & 1.0 & -0.6 & -0.8 & 12.4 & 12.4 & 18.0 \\
\hline Austria & 6.6 & 0.2 & 0.5 & -0.3 & -0.2 & 4.6 & 4.8 & 0.4 & 1.0 & -0.9 & -0.6 & 8.8 & 8.8 & 15.4 \\
\hline Belgium & 5.8 & 0.2 & 0.3 & -0.3 & -0.3 & 1.6 & 1.5 & 0.3 & 0.7 & -0.8 & -0.7 & 2.6 & 2.1 & 7.9 \\
\hline Canada & 5.8 & 0.3 & 0.6 & -0.3 & -0.3 & 2.0 & 2.3 & 0.5 & 0.9 & -0.7 & -0.7 & 3.4 & 3.4 & 9.3 \\
\hline Chile & 3.1 & 0.4 & 0.8 & -0.2 & -0.6 & 1.5 & 1.8 & 0.7 & 1.8 & -0.7 & -1.1 & 2.5 & 3.2 & 6.3 \\
\hline Czech Republic & 5.5 & 0.3 & 0.6 & -0.4 & -0.5 & -1.0 & -1.1 & 0.5 & 1.2 & -1.0 & -0.9 & -1.5 & -1.7 & 3.8 \\
\hline Denmark & 6.3 & 0.2 & 0.5 & -0.3 & -0.2 & 4.2 & 4.3 & 0.3 & 0.8 & -0.8 & -0.7 & 7.8 & 7.4 & 13.7 \\
\hline Estonia & 4.3 & 0.2 & 0.4 & -0.4 & -0.5 & 1.5 & 1.1 & 0.3 & 1.1 & -0.8 & -1.1 & 2.5 & 2.0 & 6.2 \\
\hline Finland & 5.2 & 0.2 & 0.5 & -0.4 & -0.3 & 3.5 & 3.5 & 0.3 & 0.7 & -0.7 & -0.7 & 6.4 & 6.0 & 11.3 \\
\hline France & 7.4 & 0.1 & 0.5 & -0.3 & -0.3 & 0.1 & 0.0 & 0.3 & 0.8 & -0.8 & -0.6 & 0.1 & -0.2 & 7.2 \\
\hline Germany & 7.3 & 0.2 & 0.6 & -0.4 & -0.3 & 1.1 & 1.3 & 0.4 & 1.0 & -0.9 & -0.7 & 1.8 & 1.7 & 8.9 \\
\hline & 5.4 & 0.2 & 0.4 & -0.3 & -0.3 & 3.0 & 3.0 & 0.4 & 1.0 & & & & & 10.8 \\
\hline Hungary & 4.8 & 0.2 & 0.5 & -0.5 & -0.5 & 0.4 & 0.1 & 0.4 & 1.3 & -1.3 & -1.0 & 0. & 0.0 & 4.8 \\
\hline Iceland & 5.8 & 0.0 & 0.5 & -0.3 & -0.2 & 8.4 & 8.5 & 0.1 & 0.7 & -0.6 & -0.7 & 18.2 & 17.7 & 23.5 \\
\hline Israel & 4.0 & 0.2 & 0.4 & -0.3 & -0.2 & 1.5 & 1.5 & 0.5 & 0.9 & -0.7 & -0.7 & 2.5 & 2.5 & 6.6 \\
\hline Ireland & 5.5 & 0.1 & 0.5 & -0.3 & -0.2 & 1.5 & 1.6 & 0.3 & 1.0 & -0.8 & -0.5 & 2.5 & 2.5 & 8.0 \\
\hline Italy & 6.1 & 0.2 & 0.4 & -0.3 & -0.2 & 0.4 & 0.6 & 0.4 & 1.0 & -0.7 & -0.6 & 0.7 & 0.8 & 6.9 \\
\hline Japan & 6.1 & 0.3 & 0.7 & -0.3 & -0.3 & 1.5 & 1.8 & 0.4 & 1.0 & -0.7 & -0.8 & 2.5 & 2.5 & 8.6 \\
\hline Korea & 3.3 & 0.4 & 1.1 & -0.4 & -0.5 & 1.7 & 2.4 & 0.8 & 2.1 & -0.8 & -0.8 & 2.9 & 4.1 & 7.5 \\
\hline Luxembourg & 4.4 & 0.2 & 0.5 & -0.3 & -0.1 & 0.9 & 1.2 & 0.5 & 1.1 & -0.9 & -0.2 & 1.5 & 2.1 & 6.5 \\
\hline Mexico & 2.5 & 0.2 & 0.7 & -0.3 & -0.5 & 1.5 & 1.6 & 0.5 & 2.0 & -0.9 & -1.1 & 2.5 & 3.0 & 5.5 \\
\hline Netherlands & 6.4 & 0.3 & 0.6 & -0.3 & -0.3 & -0.2 & 0.1 & 0.4 & 1.0 & -0.8 & -0.7 & -0.2 & -0.3 & 6.1 \\
\hline New Zealand & 6.4 & 0.3 & 0.5 & -0.3 & -0.3 & 2.6 & 2.7 & 0.5 & 1.0 & -0.6 & -0.9 & 4.5 & 4.4 & 10.9 \\
\hline Norway & 5.1 & 0.2 & 0.4 & -0.3 & -0.4 & 0.6 & 0.5 & 0.4 & 0.8 & -0.7 & -0.7 & 0.9 & 0.7 & 5.7 \\
\hline Poland & 4.1 & 0.3 & 0.7 & -0.5 & -0.5 & -2.1 & -2.2 & 0.5 & 1.7 & -1.3 & -0.9 & -2.9 & -2.8 & 1.3 \\
\hline Portugal & 6.5 & 0.2 & 0.5 & -0.4 & -0.2 & 5.6 & 5.7 & 0.5 & 1.2 & -0.9 & -0.7 & 11.2 & 11.3 & 17.8 \\
\hline Slovak Republic & 5.4 & 0.3 & 0.7 & -0.5 & -0.5 & -3.3 & -3.3 & 0.7 & 1.8 & -1.4 & -0.9 & -4.0 & -3.8 & 1.6 \\
\hline Slovenia & 5.2 & 0.3 & 0.6 & -0.4 & -0.3 & 1.5 & 1.7 & 0.5 & 1.2 & -0.7 & -0.8 & 2.5 & 2.7 & 7.9 \\
\hline Spain & 5.6 & 0.2 & 0.5 & -0.3 & -0.3 & 4.4 & 4.5 & 0.5 & 1.3 & -0.8 & -0.6 & 8.3 & 8.7 & 14.3 \\
\hline Sweden & 6.6 & 0.2 & 0.3 & -0.3 & -0.3 & 1.2 & 1.1 & 0.3 & 0.6 & -0.7 & -0.7 & 2.1 & 1.6 & 8.2 \\
\hline Switzerland & 5.7 & 0.2 & 0.5 & -0.3 & -0.3 & 2.1 & 2.2 & 0.5 & 1.1 & -0.8 & -0.8 & 3.6 & 3.7 & 9.4 \\
\hline & 3.8 & 0.4 & 0.7 & -0.3 & -0.6 & 1.5 & 1.5 & 0.8 & 1.9 & -1.0 & -1.1 & 2.5 & & 7.0 \\
\hline United Kin & 6.5 & 0.1 & 0.3 & -0.3 & -0.2 & 0.1 & 0.1 & 0.3 & 0.7 & -0.7 & -0.7 & 0.2 & -0.3 & 6.3 \\
\hline United States & 7.1 & 0.2 & 0.5 & -0.3 & -0.3 & 0.5 & 0.6 & 0.3 & 0.7 & -0.6 & -0.7 & 0.8 & 0.6 & 7.7 \\
\hline$O E C D$ average ${ }^{1}$ & 5.5 & 0.2 & 0.5 & -0.4 & -0.3 & 1.8 & 1.9 & 0.4 & 1.1 & -0.8 & -0.8 & 3.4 & 3.4 & 8.8 \\
\hline Brazil & 3.7 & 0.3 & 0.8 & -0.3 & -0.6 & 1.5 & 1.6 & 0.6 & 2.1 & -1.0 & -1.1 & 2.5 & 3.1 & 6.8 \\
\hline & 1.9 & 0.4 & 0.9 & -0.4 & & 1.5 & 1.3 & 0.7 & 2.0 & -1. & -1.7 & 2.5 & 2.5 & 4.4 \\
\hline & 1.2 & 0.2 & 0 & -0.4 & -1.0 & 1.5 & 0.8 & 0.6 & 1.5 & -1. & -1.7 & 2. & 6 & 2.8 \\
\hline esia & 1.2 & 0.3 & 0. & -0.4 & -0.8 & 1.5 & 1.3 & 7 & 2.0 & -1.3 & -1.5 & 2.5 & 2.3 & 3.5 \\
\hline Russia & 3.1 & 0.2 & 0.4 & -0.4 & -0.6 & 1.5 & 1.0 & 0.3 & 0.9 & -1.0 & -1.0 & 2.5 & 1.6 & 4.7 \\
\hline South Africa & 3.2 & 0.1 & 0.4 & -0.5 & -0.6 & 1.5 & 0.9 & 0.3 & 1.1 & -1.4 & -1.2 & 2.5 & 1.3 & 4.5 \\
\hline Non-OECD average ${ }^{1}$ & 2.4 & 0.2 & 0.6 & -0.4 & -0.8 & 1.5 & 1.2 & 0.5 & 1.6 & -1.2 & -1.4 & 2.5 & 2.1 & 4.4 \\
\hline Total average ${ }^{1}$ & 5.0 & 0.2 & 0.5 & -0.4 & -0.4 & 1.7 & 1.8 & 0.5 & 1.2 & -0.9 & -0.8 & 3.3 & 3.2 & 8.2 \\
\hline
\end{tabular}


Table A5.7. Breakdown of the projections of public health care expenditure for each driver

Compression of morbidity

\begin{tabular}{|c|c|c|c|c|c|c|c|c|c|c|c|c|c|c|}
\hline & $\begin{array}{c}\text { Health } \\
\text { expenditure } \\
\text { as a \% of } \\
\text { GDP }\end{array}$ & $\begin{array}{l}\text { Death- } \\
\text { related } \\
\text { costs }\end{array}$ & $\begin{array}{l}\begin{array}{c}\text { Pure age } \\
\text { effect } \\
\text { (surivors) }\end{array}\end{array}$ & $\begin{array}{l}\text { Adjustment } \\
\text { for healthy } \\
\text { ageing }\end{array}$ & $\begin{array}{l}\text { Income } \\
\text { effect }\end{array}$ & $\begin{array}{l}\text { Non-ageing } \\
\text { residual } \\
\text { effect }\end{array}$ & Total & $\begin{array}{l}\text { Death- } \\
\text { related } \\
\text { costs }\end{array}$ & $\begin{array}{l}\begin{array}{l}\text { Pure age } \\
\text { effect } \\
\text { (surivivors) }\end{array}\end{array}$ & $\begin{array}{l}\text { Adjustment } \\
\text { for healthy } \\
\text { ageing }\end{array}$ & $\begin{array}{l}\text { Income } \\
\text { effect }\end{array}$ & $\begin{array}{c}\text { Non-ageing } \\
\text { residual } \\
\text { effect }\end{array}$ & Total & \begin{tabular}{|c|c} 
Health \\
expenditure \\
as a \% of \\
GDP
\end{tabular} \\
\hline & $\begin{array}{c}\text { Average } \\
2006-2010\end{array}$ & \multicolumn{6}{|c|}{ Increase in \% points of GDP 2010-2030 } & \multicolumn{6}{|c|}{ Increase in \% points of GDP 2010-2060 } & 2060 \\
\hline Australia & 5.6 & 0.2 & 0.5 & -0.5 & -0.4 & 1.5 & 1.3 & 0.5 & 1.0 & -1.2 & -0.8 & 2.5 & 1.9 & 7.5 \\
\hline Austria & 6.6 & 0.2 & & -0.6 & -0.2 & 1.5 & 1.4 & 0.4 & 1.0 & -1.5 & -0.6 & 2.5 & 1.8 & 8.4 \\
\hline Belgium & 5.8 & 0.2 & 0.3 & -0.6 & -0.3 & 1.5 & 1.1 & 0.3 & 0.7 & -1.4 & -0.7 & 2.5 & 1.3 & 7.1 \\
\hline Canada & 5.8 & 0.3 & 0.6 & -0.6 & -0.3 & 1.5 & 1.6 & 0.5 & 0.9 & -1.2 & -0.7 & 2.5 & 1.9 & 7.8 \\
\hline Chile & 3.1 & 0.4 & 0.8 & -0.4 & -0.6 & 1.5 & 1.6 & 0.7 & 1.8 & -1.3 & -1.1 & 2.5 & 2.6 & 5.7 \\
\hline Czech Republic & 5.5 & 0.3 & 0.6 & -0.8 & -0.5 & 1.5 & 1.0 & 0.5 & 1.2 & -1.9 & -0.9 & 2.5 & 1.4 & 6.9 \\
\hline Denmark & 6.3 & 0.2 & 0.5 & -0.6 & -0.2 & 1.5 & 1.3 & 0.3 & 0.8 & -1.5 & -0.7 & 2.5 & 1.4 & 7.6 \\
\hline Estonia & 4.3 & 0.2 & 0.4 & -0.6 & -0.5 & 1.5 & 0.9 & 0.3 & 1.1 & -1.5 & -1.1 & 2.5 & 1.3 & 5.5 \\
\hline Finland & 5.2 & 0.2 & 0.5 & -0.6 & -0.3 & 1.5 & 1.2 & 0.3 & 0.7 & -1.4 & -0.7 & 2.5 & 1.4 & 6.6 \\
\hline France & 7.4 & 0.1 & 0.5 & -0.6 & -0.3 & 1.5 & 1.2 & 0.3 & 0.8 & -1.3 & -0.6 & 2.5 & 1.6 & 9.0 \\
\hline Germany & 7.3 & 0.2 & 0.6 & -0.6 & -0.3 & 1.5 & 1.4 & 0.4 & 1.0 & -1.6 & -0.7 & 2.5 & 1.6 & 8.9 \\
\hline & 5.4 & 0.2 & 0.4 & -0.6 & -0.3 & 1.5 & 1.2 & 0.4 & 1.0 & -1.5 & & & & 7.2 \\
\hline Hungary & 4.8 & 0.2 & 0.5 & -0.9 & -0.5 & 1.5 & 0.7 & 0.4 & 1.3 & -2.2 & -1.0 & 2. & 1.0 & 5.8 \\
\hline Iceland & 5.8 & 0.0 & 0.5 & -0.5 & -0.2 & 1.5 & 1.3 & 0.1 & 0.7 & -1.1 & -0.7 & 2. & 1.4 & 7.3 \\
\hline Israel & 4.0 & 0.2 & 0.4 & -0.4 & -0.2 & 1.5 & 1.4 & 0.5 & 0.9 & -1.2 & -0.7 & 2.5 & 2.0 & 6.0 \\
\hline Ireland & 5.5 & 0.1 & 0.5 & -0.6 & -0.2 & 1.5 & 1.3 & 0.3 & 1.0 & -1.5 & -0.5 & 2.5 & 1.8 & 7.4 \\
\hline Italy & 6.1 & 0.2 & 0.4 & -0.6 & -0.2 & 1.5 & 1.3 & 0.4 & 1.0 & -1.4 & -0.6 & 2.5 & 1.9 & 8.0 \\
\hline Japan & 6.1 & 0.3 & 0.7 & -0.6 & -0.3 & 1.5 & 1.6 & 0.4 & 1.0 & -1.2 & -0.8 & 2.5 & 1.9 & 8.0 \\
\hline Korea & 3.3 & 0.4 & 1.1 & -0.6 & -0.5 & 1.5 & 1.9 & 0.8 & 2.1 & -1.5 & -0.8 & 2.5 & 3.0 & 6.3 \\
\hline Luxembourg & 4.4 & 0.2 & 0.5 & -0.6 & -0.1 & 1.5 & 1.4 & 0.5 & 1.1 & -1.6 & -0.2 & 2.5 & 2.3 & 6.7 \\
\hline Mexico & 2.5 & 0.2 & 0.7 & -0.5 & -0.5 & 1.5 & 1.4 & 0.5 & 2.0 & -1.6 & -1.1 & 2.5 & 2.3 & 4.8 \\
\hline Netherlands & 6.4 & 0.3 & 0.6 & -0.7 & -0.3 & 1.5 & 1.4 & 0.4 & 1.0 & -1.4 & -0.7 & 2.5 & 1.8 & 8.2 \\
\hline New Zealand & 6.4 & 0.3 & 0.5 & -0.5 & -0.3 & 1.5 & 1.4 & 0.5 & 1.0 & -1.2 & -0.9 & 2.5 & 1.8 & 8.2 \\
\hline Norway & 5.1 & 0.2 & 0.4 & -0.6 & -0.4 & 1.5 & 1.1 & 0.4 & 0.8 & -1.3 & -0.7 & 2.5 & 1.6 & 6.7 \\
\hline Poland & 4.1 & 0.3 & 0.7 & -0.9 & -0.5 & 1.5 & 1.0 & 0.5 & 1.7 & -2.3 & -0.9 & 2.5 & 1.5 & 5.6 \\
\hline Portugal & 6.5 & 0.2 & 0.5 & -0.7 & -0.2 & 1.5 & 1.3 & 0.5 & 1.2 & -1.7 & -0.7 & 2.5 & 1.8 & 8.3 \\
\hline Slovak Republic & 5.4 & 0.3 & 0.7 & -0.9 & -0.5 & 1.5 & 1.1 & 0.7 & 1.8 & -2.4 & -0.9 & 2.5 & 1.6 & 7.0 \\
\hline Slovenia & 5.2 & 0.3 & 0.6 & -0.6 & -0.3 & 1.5 & 1.5 & 0.5 & 1.2 & -1.4 & -0.8 & 2.5 & 2.0 & 7.2 \\
\hline Spain & 5.6 & 0.2 & 0.5 & -0.6 & -0.3 & 1.5 & 1.3 & 0.5 & 1.3 & -1.5 & -0.6 & 2.5 & 2.2 & 7.8 \\
\hline Sweden & 6.6 & 0.2 & 0.3 & -0.5 & -0.3 & 1.5 & 1.1 & 0.3 & 0.6 & -1.3 & -0.7 & 2.5 & 1.4 & 8.0 \\
\hline Switzerland & 5.7 & 0.2 & 0.5 & -0.6 & -0.3 & 1.5 & 1.4 & 0.5 & 1.1 & -1.4 & -0.8 & 2.5 & 2.0 & 7.7 \\
\hline & 3.8 & 0.4 & 0.7 & -0.6 & -0.6 & 1.5 & 1.3 & 0.8 & 1.9 & -1.7 & -1.1 & 2.5 & 2.4 & 6.2 \\
\hline United Kir & 6.5 & 0.1 & 0.3 & -0.6 & -0.2 & 1.5 & 1.1 & 0.3 & 0.7 & -1.4 & -0.7 & 2.5 & 1.3 & 7.9 \\
\hline United States & 7.1 & 0.2 & 0.5 & -0.5 & -0.3 & 1.5 & 1.4 & 0.3 & 0.7 & -1.2 & -0.7 & 2.5 & 1.7 & 8.8 \\
\hline$O E C D$ average ${ }^{1}$ & 5.5 & 0.2 & 0.5 & -0.6 & -0.3 & 1.5 & 1.3 & 0.4 & 1.1 & -1.5 & -0.8 & 2.5 & 1.8 & 7.2 \\
\hline Brazil & 3.7 & 0.3 & 0.8 & -0.6 & -0.6 & 1.5 & 1.3 & 0.6 & 2.1 & -1.8 & -1.1 & 2.5 & 2.3 & 6.0 \\
\hline & 1.9 & 0.4 & & -0.7 & & 1.5 & 0.9 & 0.7 & 2.0 & -1.9 & -1.7 & 2.5 & 1.6 & 3.6 \\
\hline Ind & 1.2 & 0.2 & & -0.7 & -1 & 1.5 & 0.6 & 0.6 & 1. & -2 & -1.7 & 2.5 & 0.9 & 2.1 \\
\hline esia & 1.2 & 0.3 & 0 & -0.7 & -0.8 & 1.5 & 0.9 & 0.7 & 2.0 & -2.2 & -1.5 & 2.5 & 1.4 & 2.5 \\
\hline Russia & 3.1 & 0.2 & 0.4 & -0.8 & -0.6 & 1.5 & 0.7 & 0.3 & 0.9 & -1.7 & -1.0 & 2.5 & 0.9 & 4.1 \\
\hline South Africa & 3.2 & 0.1 & 0.4 & -0.9 & -0.6 & 1.5 & 0.5 & 0.3 & 1.1 & -2.0 & -1.2 & 2.5 & 0.7 & 3.9 \\
\hline Non-OECD average ${ }^{1}$ & 2.4 & 0.2 & 0.6 & -0.7 & -0.8 & 1.5 & 0.8 & 0.5 & 1.6 & -1.9 & -1.4 & 2.5 & 1.3 & 3.7 \\
\hline Total average $^{1}$ & 5.0 & 0.2 & 0.5 & -0.6 & -0.4 & 1.5 & 1.2 & 0.5 & 1.2 & -1.6 & -0.8 & 2.5 & 1.7 & 6.7 \\
\hline
\end{tabular}


Table A5.8. Breakdown of the projections of public health care expenditure for each driver

ECO/WKP(2013)40

Expansion of morbidity

\begin{tabular}{|c|c|c|c|c|c|c|c|c|c|c|c|c|c|c|}
\hline & $\begin{array}{c}\text { Health } \\
\text { expenditure } \\
\text { as a \% of } \\
\text { GDP } \\
\end{array}$ & $\begin{array}{l}\text { Death- } \\
\text { related } \\
\text { costs }\end{array}$ & $\begin{array}{c}\begin{array}{c}\text { Pure age } \\
\text { effect } \\
\text { (survivors) }\end{array}\end{array}$ & $\begin{array}{l}\text { Adjustment } \\
\text { for healthy } \\
\text { ageing }\end{array}$ & $\begin{array}{c}\text { Income } \\
\text { effect }\end{array}$ & $\begin{array}{c}\text { Non-ageing } \\
\text { residual } \\
\text { effect }\end{array}$ & Total & $\begin{array}{l}\text { Death- } \\
\text { related } \\
\text { costs }\end{array}$ & $\begin{array}{c}\begin{array}{c}\text { Pure age } \\
\text { effect } \\
\text { (survivors) }\end{array}\end{array}$ & $\begin{array}{l}\text { Adjustment } \\
\text { for healthy } \\
\text { ageing }\end{array}$ & $\begin{array}{c}\text { Income } \\
\text { effect }\end{array}$ & $\begin{array}{c}\text { Non-ageing } \\
\text { residual } \\
\text { effect }\end{array}$ & Total & \begin{tabular}{|c|} 
Health \\
expenditure \\
as a \% of \\
GDP \\
\end{tabular} \\
\hline & $\begin{array}{c}\text { Average } \\
2006-2010 \\
\end{array}$ & \multicolumn{6}{|c|}{ Increase in \% points of GDP 2010-2030 } & \multicolumn{6}{|c|}{ Increase in \% points of GDP 2010-2060 } & 2060 \\
\hline Australia & 5.6 & 0.2 & 0.5 & 0.0 & -0.4 & 1.5 & 1.8 & 0.5 & 1.0 & 0.0 & -0.8 & 2.5 & 3.1 & 8.7 \\
\hline Austria & 6.6 & 0.2 & 0.5 & 0.0 & -0.2 & 1.5 & 2.0 & 0.4 & 1.0 & 0.0 & -0.6 & 2.5 & 3.3 & 9.9 \\
\hline Belgium & 5.8 & 0.2 & 0.3 & 0.0 & -0.3 & 1.5 & 1.7 & 0.3 & 0.7 & 0.0 & -0.7 & 2.5 & 2.7 & 8.5 \\
\hline Canada & 5.8 & 0.3 & 0.6 & 0.0 & -0.3 & 1.5 & 2.1 & 0.5 & 0.9 & 0.0 & -0.7 & 2.5 & 3.1 & 9.0 \\
\hline Chile & 3.1 & 0.4 & 0.8 & 0.0 & -0.6 & 1.5 & 2.0 & 0.7 & 1.8 & 0.0 & -1.1 & 2.5 & 3.9 & 6.9 \\
\hline Czech Republic & 5.5 & & 0.6 & 0.0 & $\begin{array}{r}-0.5 \\
-0.5\end{array}$ & & & 0.5 & 1.2 & 0.0 & -0.9 & 2.5 & 3.2 & 8.8 \\
\hline $\begin{array}{l}\text { Denmark } \\
\text { Estonia }\end{array}$ & $\begin{array}{l}6.3 \\
4.3\end{array}$ & $\begin{array}{l}0.2 \\
0.2\end{array}$ & $\begin{array}{l}0.5 \\
0.4\end{array}$ & $\begin{array}{l}0.0 \\
0.0\end{array}$ & $\begin{array}{l}-0.2 \\
-0.5\end{array}$ & $\begin{array}{l}1.5 \\
1.5\end{array}$ & $\begin{array}{l}2.0 \\
1.5\end{array}$ & $\begin{array}{l}0.3 \\
0.3\end{array}$ & $\begin{array}{l}0.8 \\
1.1\end{array}$ & $\begin{array}{l}0.0 \\
0.0\end{array}$ & $\begin{array}{r}-0.7 \\
-1.1\end{array}$ & $\begin{array}{l}2.5 \\
25\end{array}$ & $\begin{array}{l}2.9 \\
2.8\end{array}$ & $\begin{array}{l}9.1 \\
7.1\end{array}$ \\
\hline Finland & 5.2 & 0.2 & 0.5 & 0.0 & -0.3 & 1.5 & 1.9 & 0.3 & 0.7 & 0.0 & -0.7 & 2.5 & $\begin{array}{l}2.0 \\
2.8\end{array}$ & 8.0 \\
\hline $\begin{array}{l}\text { Finland } \\
\text { France }\end{array}$ & $\begin{array}{l}5.2 \\
7.4\end{array}$ & $\begin{array}{l}0.2 \\
0.1\end{array}$ & $\begin{array}{l}0.5 \\
0.5\end{array}$ & 0.0 & -0.3 & 1.5 & 1.8 & 0.3 & 0.8 & 0.0 & -0.6 & 2.5 & 2.9 & 10.3 \\
\hline Germany & 7.3 & 0.2 & 0.6 & 0.0 & -0.3 & 1.5 & 2.0 & 0.4 & 1.0 & 0.0 & -0.7 & 2.5 & 3.2 & 10.5 \\
\hline Greece & 5.4 & 0.2 & 0.4 & 0.0 & -0.3 & 1.5 & 1.8 & 0.4 & 1.0 & 0.0 & -0.6 & 2.5 & 3.3 & 8.7 \\
\hline Hungary & 4.8 & 0.2 & 0.5 & 0.0 & -0.5 & 1.5 & 1.7 & 0.4 & 1.3 & 0.0 & -1.0 & 2.5 & 3.2 & 8.0 \\
\hline Iceland & 5.8 & 0.0 & 0.5 & 0.0 & -0.2 & 1.5 & 1.8 & 0.1 & 0.7 & 0.0 & -0.7 & 2.5 & 2.6 & 8.4 \\
\hline Israel & 4.0 & 0.2 & 0.4 & 0.0 & -0.2 & 1.5 & 1.8 & 0.5 & 0.9 & 0.0 & -0.7 & 2.5 & 3.2 & 7.2 \\
\hline Ireland & 5.5 & 0.1 & 0.5 & 0.0 & -0.2 & 1.5 & 1.9 & 0.3 & 1.0 & 0.0 & -0.5 & 2.5 & 3.3 & 8.8 \\
\hline Italy & 6.1 & 0.2 & 0.4 & 0.0 & -0.2 & 1.5 & 1.9 & 0.4 & 1.0 & 0.0 & -0.6 & 2.5 & 3.3 & 9.4 \\
\hline Japan & 6.1 & 0.3 & 0.7 & 0.0 & -0.3 & 1.5 & 2.1 & 0.4 & 1.0 & 0.0 & -0.8 & 2.5 & 3.1 & 9.2 \\
\hline Korea & 3.3 & 0.4 & 1.1 & 0.0 & -0.5 & 1.5 & 2.5 & 0.8 & 2.1 & 0.0 & -0.8 & 2.5 & 4.5 & 7.8 \\
\hline Luxembourg & 4.4 & 0.2 & 0.5 & 0.0 & -0.1 & 1.5 & 2.0 & 0.5 & 1.1 & 0.0 & -0.2 & 2.5 & 3.9 & 8.3 \\
\hline Mexico & 2.5 & 0.2 & 0.7 & 0.0 & -0.5 & 1.5 & 1.9 & 0.5 & 2.0 & 0.0 & -1.1 & 2.5 & 3.9 & 6.4 \\
\hline Netherlands & 6.4 & 0.3 & 0.6 & 0.0 & -0.3 & 1.5 & 2.1 & 0.4 & 1.0 & 0.0 & -0.7 & 2.5 & 3.2 & 9.6 \\
\hline New Zealand & 6.4 & 0.3 & 0.5 & 0.0 & -0.3 & 1.5 & 2.0 & 0.5 & 1.0 & 0.0 & -0.9 & 2.5 & 3.0 & 9.5 \\
\hline Norway & 5.1 & 0.2 & 0.4 & 0.0 & -0.4 & 1.5 & 1.7 & 0.4 & 0.8 & 0.0 & -0.7 & 2.5 & 3.0 & 8.1 \\
\hline Poland & 4.1 & 0.3 & 0.7 & 0.0 & -0.5 & 1.5 & 1.9 & 0.5 & 1.7 & 0.0 & -0.9 & 2.5 & 3.9 & 8.0 \\
\hline Portugal & 6.5 & 0.2 & 0.5 & 0.0 & -0.2 & 1.5 & 2.0 & 0.5 & 1.2 & 0.0 & -0.7 & 2.5 & 3.5 & 10.0 \\
\hline Slovak Republic & 5.4 & 0.3 & 0.7 & 0.0 & -0.5 & 1.5 & 2.0 & 0.7 & 1.8 & 0.0 & -0.9 & 2.5 & 4.0 & 9.4 \\
\hline Slovenia & 5.2 & 0.3 & 0.6 & 0.0 & -0.3 & 1.5 & 2.0 & 0.5 & 1.2 & 0.0 & -0.8 & 2.5 & 3.5 & 8.6 \\
\hline Spain & 5.6 & 0.2 & 0.5 & 0.0 & -0.3 & 1.5 & 1.9 & 0.5 & 1.3 & 0.0 & -0.6 & 2.5 & 3.6 & 9.2 \\
\hline Sweden & 6.6 & 0.2 & 0.3 & 0.0 & -0.3 & 1.5 & 1.6 & 0.3 & 0.6 & 0.0 & -0.7 & 2.5 & 2.7 & 9.2 \\
\hline Switzerland & 5.7 & 0.2 & 0.5 & 0.0 & -0.3 & 1.5 & 2.0 & 0.5 & 1.1 & 0.0 & -0.8 & 2.5 & 3.3 & 9.0 \\
\hline Turkey & 3.8 & 0.4 & 0.7 & 0.0 & -0.6 & 1.5 & 1.9 & 0.8 & 1.9 & 0.0 & -1.1 & 2.5 & 4.1 & 7.9 \\
\hline United Kingdom & 6.5 & 0.1 & 0.3 & 0.0 & -0.2 & 1.5 & 1.7 & 0.3 & 0.7 & 0.0 & -0.7 & 2.5 & 2.7 & 9.2 \\
\hline United States & 7.1 & 0.2 & 0.5 & 0.0 & -0.3 & 1.5 & 1.9 & 0.3 & 0.7 & 0.0 & -0.7 & 2.5 & 2.9 & 9.9 \\
\hline$O E C D$ average ${ }^{1}$ & 5.5 & 0.2 & 0.5 & 0.0 & -0.3 & 1.5 & 1.9 & 0.4 & 1.1 & 0.0 & -0.8 & 2.5 & 3.3 & 8.7 \\
\hline Brazil & 3.7 & 0.3 & 0.8 & 0.0 & -0.6 & 1.5 & 1.9 & 0.6 & 2.1 & 0.0 & -1.1 & 2.5 & 4.1 & 7.8 \\
\hline China & 1.9 & 0.4 & 0.9 & 0.0 & -1.1 & 1.5 & 1.6 & 0.7 & 2.0 & 0.0 & -1.7 & 2.5 & 3.5 & 5.5 \\
\hline India & 1.2 & 0.2 & 0.5 & 0.0 & -1.0 & 1.5 & 1.2 & 0.6 & 1.5 & 0.0 & -1.7 & 2.5 & 2.8 & 4.0 \\
\hline Indonesia & 1.2 & 0.3 & 0.7 & 0.0 & -0.8 & 1.5 & 1.7 & 0.7 & 2.0 & 0.0 & -1.5 & 2.5 & 3.6 & 4.8 \\
\hline Russia & 3.1 & 0.2 & 0.4 & 0.0 & -0.6 & 1.5 & 1.4 & 0.3 & 0.9 & 0.0 & -1.0 & 2.5 & 2.6 & 5.7 \\
\hline South Africa & 3.2 & 0.1 & 0.4 & 0.0 & -0.6 & 1.5 & 1.4 & 0.3 & 1.1 & 0.0 & -1.2 & 2.5 & 2.7 & 5.9 \\
\hline Non-OECD average ${ }^{1}$ & 2.4 & 0.2 & 0.6 & 0.0 & -0.8 & 1.5 & 1.5 & 0.5 & 1.6 & 0.0 & -1.4 & 2.5 & 3.2 & 5.6 \\
\hline Total average ${ }^{1}$ & 5.0 & 0.2 & 0.5 & 0.0 & -0.4 & 1.5 & 1.9 & 0.5 & 1.2 & 0.0 & -0.8 & 2.5 & 3.3 & 8.3 \\
\hline
\end{tabular}


Table A5.9. Breakdown of the projections of total long-term care expenditure for each driver

Demographic scenario

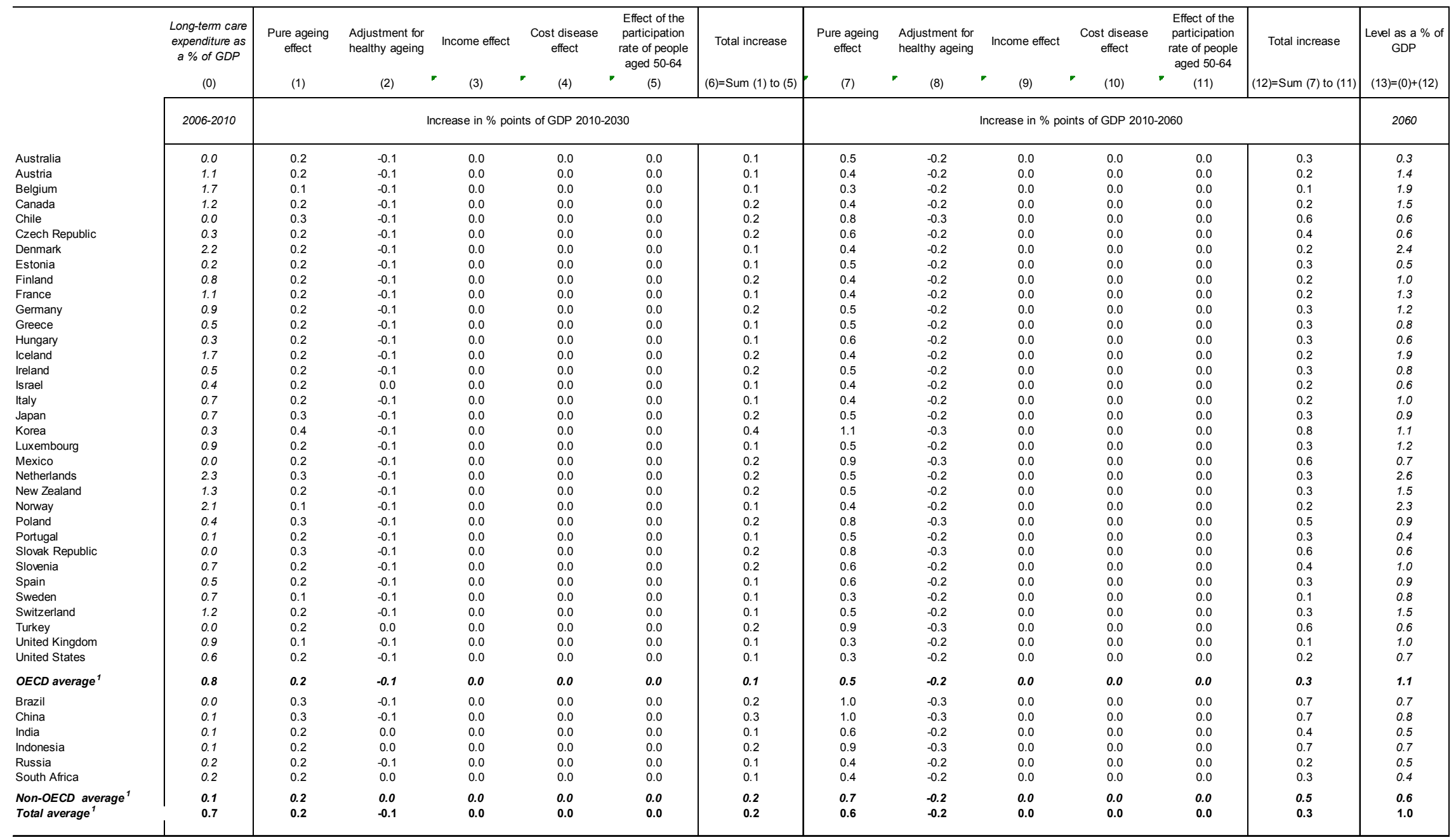


Table A5.10. Breakdown of the projections of total long-term care expenditure for each driver

ECO/WKP(2013)40

Cost-pressure scenario

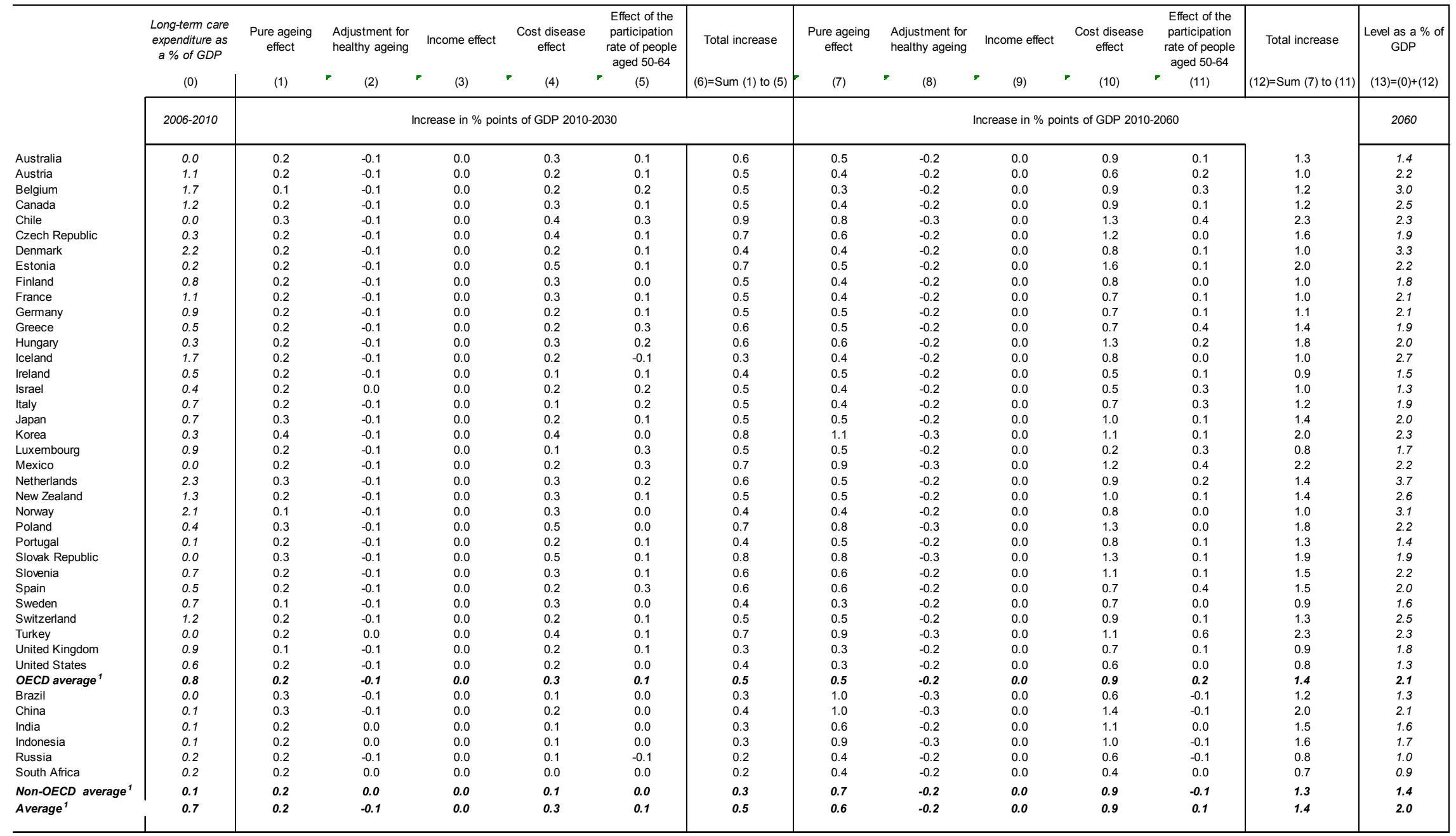


Table A5.11. Breakdown of the projections of total long-term care expenditure for each driver

Cost-containment

\begin{tabular}{|c|c|c|c|c|c|c|c|c|c|c|c|c|c|c|}
\hline & $\begin{array}{l}\text { Long-tem care } \\
\text { expenditure as } \\
\text { a \% of GDP }\end{array}$ & $\begin{array}{l}\text { Pure ageing } \\
\text { effect }\end{array}$ & $\begin{array}{l}\text { Adjustment for } \\
\text { healthy ageing }\end{array}$ & Income effect & $\begin{array}{c}\text { Cost disease } \\
\text { effect }\end{array}$ & $\begin{array}{c}\text { Effect of the } \\
\text { participation } \\
\text { rate of people } \\
\text { aged 50-64 }\end{array}$ & Total increase & $\begin{array}{c}\text { Pure ageing } \\
\text { effect }\end{array}$ & $\begin{array}{l}\text { Adjustment for } \\
\text { healthy ageing }\end{array}$ & Income effect & $\begin{array}{c}\text { Cost disease } \\
\text { effect }\end{array}$ & $\begin{array}{c}\text { Effect of the } \\
\text { participation } \\
\text { rate of people } \\
\text { aged } 50-64\end{array}$ & Total increase & $\begin{array}{c}\text { Level as a \% of } \\
\text { GDP }\end{array}$ \\
\hline & $\Rightarrow \quad(0)$ & (1) & (2) & (3) & (4) & $=\quad(5)$ & (6)=Sum (1) to (5) & (7) & (8) & (9) & $\times \quad(10)$ & $=\quad(11)$ & $(12)=\operatorname{Sum}(7)$ to $(11)$ & $(13)=(0)+(12)$ \\
\hline & $2006-2010$ & & & Increase in \% poi & ints of GDP 2010 & 0-2030 & & & & Increase in \% po & oints of GDP 2010 & 0-2060 & & 2060 \\
\hline Australia & 0.0 & 0.2 & -0.1 & 0.0 & 0.1 & 0.1 & 0.3 & 0.5 & -0.2 & 0.0 & 0.4 & 0.1 & 0.8 & 0.8 \\
\hline Austria & 1.1 & 0.2 & -0.1 & 0.0 & 0.0 & 0.1 & 0.3 & 0.4 & -0.2 & 0.0 & 0.3 & 0.2 & 0.7 & $\begin{array}{l}0.0 \\
1.8\end{array}$ \\
\hline Belgium & 1.7 & 0.1 & -0.1 & 0.0 & 0.0 & 0.2 & 0.3 & 0.3 & -0.2 & 0.0 & 0.3 & 0.3 & 0.7 & 2.5 \\
\hline Canada & 1.2 & 0.2 & -0.1 & 0.0 & 0.0 & 0.1 & 0.3 & 0.4 & -0.2 & 0.0 & 0.4 & 0.1 & 0.7 & 1.9 \\
\hline Chile & 0.0 & 0.3 & -0.1 & 0.0 & 0.1 & 0.3 & 0.6 & 0.8 & -0.3 & 0.0 & 0.5 & 0.4 & 1.5 & 1.5 \\
\hline Czech Republic & 0.3 & 0.2 & -0.1 & 0.0 & 0.1 & 0.1 & 0.3 & 0.6 & -0.2 & 0.0 & 0.5 & 0.0 & 0.9 & 1.1 \\
\hline Estonia & 0.2 & 0.2 & -0.1 & 0.0 & 0.1 & 0.1 & 0.3 & 0.5 & -0.2 & 0.0 & 0.6 & 0.1 & 0.9 & 1.1 \\
\hline Finland & 0.8 & 0.2 & -0.1 & 0.0 & 0.1 & 0.0 & 0.3 & 0.4 & -0.2 & 0.0 & 0.3 & 0.0 & 0.5 & 1.3 \\
\hline France & 1.1 & 0.2 & -0.1 & 0.0 & 0.0 & 0.1 & 0.2 & 0.4 & -0.2 & 0.0 & 0.3 & 0.1 & 0.6 & 1.7 \\
\hline Germany & 0.9 & 0.2 & -0.1 & 0.0 & 0.0 & 0.1 & 0.3 & 0.5 & -0.2 & 0.0 & 0.3 & 0.1 & 0.7 & 1.6 \\
\hline Greece & 0.5 & 0.2 & -0.1 & 0.0 & 0.0 & 0.3 & 0.4 & 0.5 & -0.2 & 0.0 & 0.3 & 0.4 & 0.9 & 1.5 \\
\hline Hungary & 0.3 & 0.2 & -0.1 & 0.0 & 0.1 & 0.2 & 0.3 & 0.6 & -0.2 & 0.0 & 0.5 & 0.2 & 1.0 & 1.2 \\
\hline $\begin{array}{l}\text { Iceland } \\
\text { Ireland }\end{array}$ & 1.7 & 0.2 & -0.1 & 0.0 & 0.0 & -0.1 & 0.1 & 0.4 & -0.2 & 0.0 & 0.3 & 0.0 & 0.5 & 2.2 \\
\hline $\begin{array}{l}\text { Ireland } \\
\text { Israel }\end{array}$ & $\begin{array}{l}0.5 \\
0.4\end{array}$ & $\begin{array}{l}0.2 \\
0.2\end{array}$ & $\begin{array}{l}-0.1 \\
0.0\end{array}$ & $\begin{array}{l}0.0 \\
0.0\end{array}$ & 0.0 & 0.1 & 0.3 & $\begin{array}{l}0.5 \\
0.4\end{array}$ & $\begin{array}{l}-0.2 \\
-0.2\end{array}$ & $\begin{array}{l}0.0 \\
0.0\end{array}$ & 0.2 & 0.1 & 0.6 & 1.2 \\
\hline Italy & 0.7 & 0.2 & $\begin{array}{l}0.1 \\
-0.1\end{array}$ & 0.0 & $\begin{array}{l}.0 \\
0.0\end{array}$ & $\begin{array}{l}0.2 \\
0.2\end{array}$ & $\begin{array}{l}0.4 \\
0.3\end{array}$ & $\begin{array}{l}0.4 \\
0.4\end{array}$ & $\begin{array}{l}-0.2 \\
-02\end{array}$ & $\begin{array}{l}0.0 \\
0.0\end{array}$ & $\begin{array}{l}0.2 \\
0.3\end{array}$ & $\begin{array}{l}0.3 \\
0.3\end{array}$ & $\begin{array}{l}0.1 \\
0.8\end{array}$ & $\begin{array}{l}1.1 \\
1.5\end{array}$ \\
\hline Japan & 0.7 & 0.3 & -0.1 & 0.0 & 0.0 & 0.1 & 0.3 & 0.5 & -0.2 & 0.0 & 0.4 & 0.1 & 0.8 & 1.4 \\
\hline Korea & 0.3 & 0.4 & -0.1 & 0.0 & 0.1 & 0.0 & 0.5 & 1.1 & -0.3 & 0.0 & 0.4 & 0.1 & 1.3 & 1.6 \\
\hline Luxembourg & 0.9 & 0.2 & -0.1 & 0.0 & 0.0 & 0.3 & 0.4 & 0.5 & -0.2 & 0.0 & 0.1 & 0.3 & 0.7 & 1.7 \\
\hline Mexico & 0.0 & 0.2 & -0.1 & 0.0 & 0.0 & 0.3 & 0.5 & 0.9 & -0.3 & 0.0 & 0.4 & 0.4 & 1.5 & 1.5 \\
\hline Netherlands & 2.3 & 0.3 & -0.1 & 0.0 & 0.0 & 0.2 & 0.4 & 0.5 & -0.2 & 0.0 & 0.3 & 0.2 & 0.8 & 3.1 \\
\hline $\begin{array}{l}\text { Poland } \\
\text { Potuag }\end{array}$ & 0.4 & 0.3 & -0.1 & 0.0 & 0.1 & 0.0 & 0.3 & 0.8 & -0.3 & 0.0 & 0.5 & 0.0 & & 1.4 \\
\hline $\begin{array}{l}\text { Portugal } \\
\text { Slovak Republic }\end{array}$ & $\begin{array}{l}0.1 \\
0.0\end{array}$ & 0.2 & -0.1 & 0.0 & 0.0 & 0.1 & 0.2 & 0.5 & -0.2 & 0.0 & 0.3 & 0.1 & 0.8 & 0.9 \\
\hline $\begin{array}{l}\text { Slovak Republic } \\
\text { Slovenia }\end{array}$ & 0.7 & 0.3 & -0.1 & 0.0 & 0.1 & 0.1 & 0.4 & 0.8 & $\begin{array}{r}-0.3 \\
-0.2\end{array}$ & $\begin{array}{l}0.0 \\
0.0\end{array}$ & 0.5 & 0.1 & 1.1 & $\begin{array}{l}1.1 \\
1 .\end{array}$ \\
\hline Spain & 0.5 & 0.2 & $\begin{array}{l}-0.1 \\
-0.1\end{array}$ & $\begin{array}{l}0.0 \\
0.0\end{array}$ & $\begin{array}{l}0.1 \\
0.0\end{array}$ & $\begin{array}{l}0.1 \\
0.3\end{array}$ & $\begin{array}{l}0.4 \\
0.5\end{array}$ & $\begin{array}{l}0.6 \\
0.6\end{array}$ & $\begin{array}{l}-0.2 \\
-0.2\end{array}$ & $\begin{array}{l}0.0 \\
0.0\end{array}$ & $\begin{array}{l}0.4 \\
0.3\end{array}$ & $\begin{array}{l}0.1 \\
0.4\end{array}$ & $\begin{array}{l}0.9 \\
1.0\end{array}$ & $\begin{array}{l}1.5 \\
1.6\end{array}$ \\
\hline Sweden & 0.7 & 0.1 & -0.1 & 0.0 & 0.1 & 0.0 & 0.1 & 0.3 & -0.2 & 0.0 & 0.3 & 0.0 & 0.5 & 1.1 \\
\hline Switzerland & 1.2 & 0.2 & -0.1 & 0.0 & 0.0 & 0.1 & 0.3 & 0.5 & -0.2 & 0.0 & 0.4 & 0.1 & 0.7 & 1.9 \\
\hline Turkey & 0.0 & 0.2 & 0.0 & 0.0 & 0.1 & 0.1 & 0.3 & 0.9 & -0.3 & 0.0 & 0.4 & 0.6 & 1.6 & 1.6 \\
\hline United Kingdom & 0.9 & 0.1 & -0.1 & 0.0 & 0.0 & 0.1 & 0.2 & 0.3 & -0.2 & 0.0 & 0.3 & 0.1 & 0.5 & 1.4 \\
\hline United States & 0.6 & 0.2 & -0.1 & 0.0 & 0.0 & 0.0 & 0.2 & 0.3 & -0.2 & 0.0 & 0.3 & 0.0 & 0.4 & 1.0 \\
\hline$O E C D$ average ${ }^{1}$ & 0.8 & 0.2 & -0.1 & 0.0 & 0.0 & 0.1 & 0.3 & 0.5 & -0.2 & 0.0 & 0.3 & 0.2 & 0.8 & 1.6 \\
\hline Brazil & 0.0 & 0.3 & -0.1 & 0.0 & 0.0 & 0.0 & 0.3 & 1.0 & -0.3 & 0.0 & 0.3 & -0.1 & 0.9 & 0.9 \\
\hline China & 0.1 & 0.3 & -0.1 & 0.0 & 0.1 & 0.0 & 0.3 & 1.0 & -0.3 & 0.0 & 0.5 & -0.1 & 1.1 & 1.2 \\
\hline India & 0.1 & 0.2 & 0.0 & 0.0 & 0.1 & 0.0 & 0.2 & 0.6 & -0.2 & 0.0 & 0.4 & 0.0 & 0.8 & 0.9 \\
\hline Indonesia & 0.1 & 0.2 & 0.0 & 0.0 & 0.1 & 0.0 & 0.2 & 0.9 & -0.3 & 0.0 & 0.4 & -0.1 & 1.0 & 1.0 \\
\hline Russia & 0.2 & 0.2 & -0.1 & 0.0 & 0.1 & -0.1 & 0.1 & 0.4 & -0.2 & 0.0 & 0.3 & -0.1 & 0.4 & 0.7 \\
\hline South Africa & 0.2 & 0.2 & 0.0 & 0.0 & 0.0 & 0.0 & 0.2 & 0.4 & -0.2 & 0.0 & 0.2 & 0.0 & 0.5 & 0.6 \\
\hline Non-OECD average ${ }^{1}$ & 0.1 & 0.2 & 0.0 & 0.0 & 0.1 & 0.0 & 0.2 & 0.7 & -0.2 & 0.0 & 0.3 & -0.1 & 0.8 & 0.9 \\
\hline Total average ${ }^{1}$ & 0.7 & 0.2 & -0.1 & 0.0 & 0.0 & 0.1 & 0.3 & 0.6 & -0.2 & 0.0 & 0.3 & 0.1 & 0.8 & 1.5 \\
\hline
\end{tabular}


Table A5.12. Breakdown of the projections of total long-term care expenditure for each driver

ECO/WKP(2013)40

Income elasticity $=2(1.5$ for non-OECD countries $)$

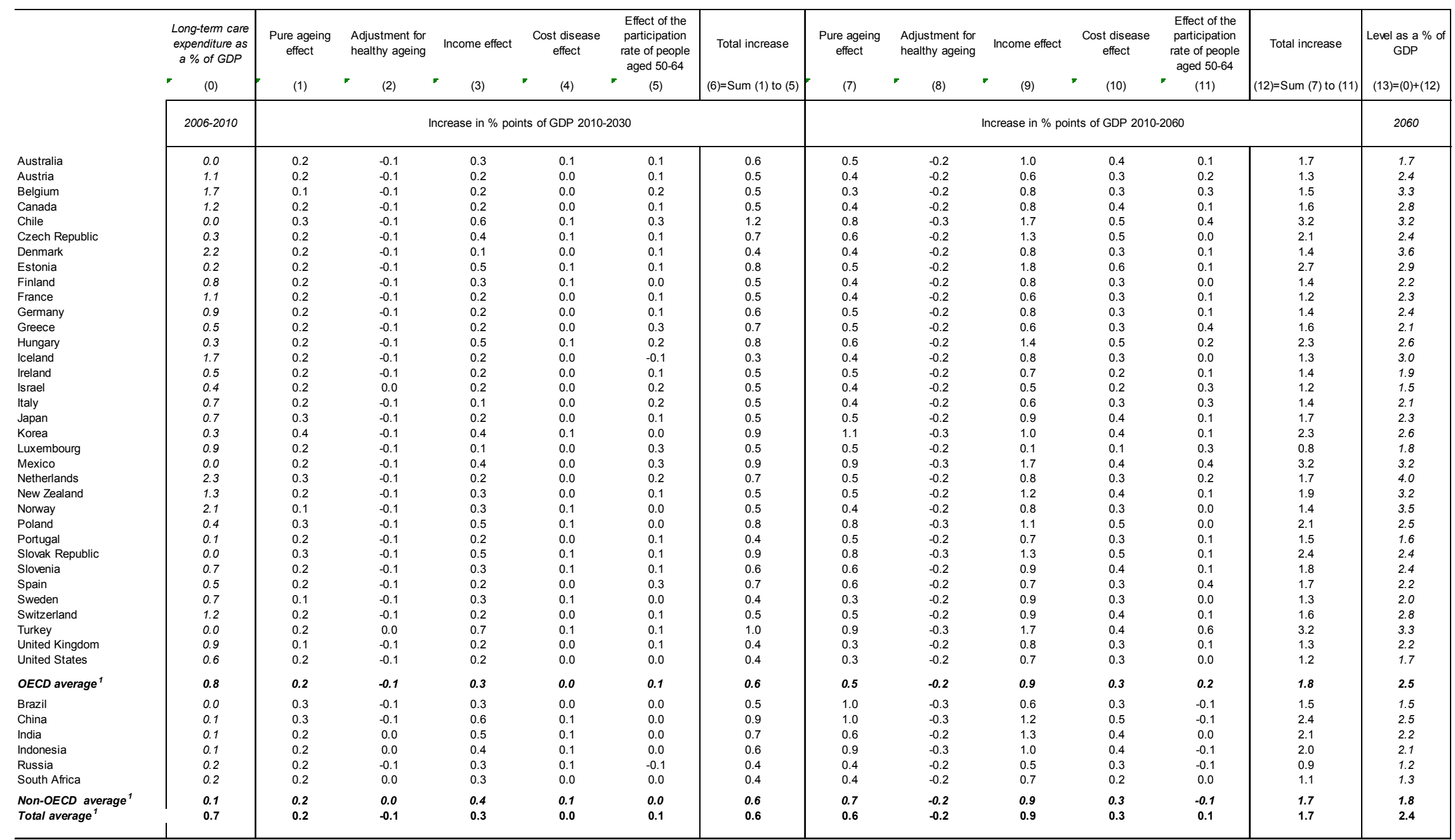


Table A5.13. Breakdown of the projections of total long-term care expenditure for each driver

Sensitivity analysis: life expectancy -2 standard deviation

\begin{tabular}{|c|c|c|c|c|c|c|c|c|c|c|c|c|c|c|}
\hline & $\begin{array}{l}\text { Long-term care } \\
\text { expenditure as } \\
\text { a \% of GDP } \\
\text { (0) }\end{array}$ & $\begin{array}{l}\text { Pure ageing } \\
\text { effect }\end{array}$ & $\begin{array}{l}\text { Adjustment for } \\
\text { healthy ageing } \\
\text { (2) }\end{array}$ & $\begin{array}{l}\text { Income effect } \\
\text { (3) }\end{array}$ & $\begin{array}{l}\begin{array}{c}\text { Cost disease } \\
\text { effect }\end{array} \\
\text { (4) }\end{array}$ & $\begin{array}{c}\text { Effect of the } \\
\text { participation } \\
\text { rate of people } \\
\text { aged 50-64 } \\
\quad \text { (5) }\end{array}$ & \begin{tabular}{|c|} 
Total increase \\
$(6)=$ Sum (1) to (5)
\end{tabular} & $\begin{array}{l}\text { Pure ageing } \\
\text { effect } \\
\text { (7) }\end{array}$ & $\begin{array}{l}\text { Adjustment for } \\
\text { healthy ageing } \\
\text { (8) }\end{array}$ & $\begin{array}{l}\text { Income effect } \\
\text { (9) }\end{array}$ & $\begin{array}{c}\begin{array}{c}\text { Cost disease } \\
\text { effect }\end{array} \\
\quad \text { (10) }\end{array}$ & $\begin{array}{c}\text { Effect of the } \\
\text { participation } \\
\text { rate of people } \\
\text { aged 50-64 } \\
(11)\end{array}$ & $\begin{array}{c}\text { Total increase } \\
(12)=\text { Sum (7) to (11) }\end{array}$ & $\begin{array}{l}\begin{array}{l}\text { Level as a \% of } \\
\text { GDP } \\
(13)=(0)+(12)\end{array}\end{array}$ \\
\hline & 2006-2010 & \multicolumn{6}{|c|}{ Increase in \% points of GDP 2010-2030 } & \multicolumn{6}{|c|}{ Increase in \% points of GDP 2010-2060 } & 2060 \\
\hline Australia & 0.0 & 0.2 & -0.1 & 0.0 & 0.1 & 0.1 & 0.3 & 0.5 & -0.4 & 0.0 & 0.4 & 0.1 & 0.6 & 0.6 \\
\hline $\begin{array}{l}\text { Austria } \\
\text { Belgium }\end{array}$ & 1.1 & 0.2 & -0.1 & 0.0 & 0.0 & 0.1 & 0.2 & 0.4 & -0.4 & 0.0 & 0.3 & 0.2 & 0.5 & 1.6 \\
\hline $\begin{array}{l}\text { Belgium } \\
\text { Canada }\end{array}$ & $\begin{array}{l}1.7 \\
1.2\end{array}$ & $\begin{array}{l}0.1 \\
0.2\end{array}$ & $\begin{array}{l}-0.1 \\
-0.1\end{array}$ & 0.0 & 0.0 & 0.2 & 0.3 & 0.3 & $\begin{array}{l}-0.3 \\
-0.4\end{array}$ & 0.0 & 0.3 & 0.3 & 0.6 & 2.3 \\
\hline Chile & 0.0 & 0.3 & -0.1 & 0.0 & 0.1 & $\begin{array}{l}0.1 \\
0.3\end{array}$ & 0.5 & 0.8 & 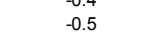 & 0.0 & $\begin{array}{l}0.4 \\
0.5\end{array}$ & 0.4 & $\begin{array}{l}0.5 \\
1.2\end{array}$ & $\begin{array}{l}1.7 \\
1.2\end{array}$ \\
\hline Czech Republic & 0.3 & 0.2 & -0.1 & 0.0 & 0.1 & 0.1 & 0.2 & 0.6 & -0.4 & 0.0 & 0.5 & 0.0 & 0.6 & 0.9 \\
\hline Estonia & 0.2 & 0.2 & -0.1 & 0.0 & 0.1 & 0.1 & 0.2 & 0.5 & -0.4 & 0.0 & 0.6 & 0.1 & 0.7 & 0.9 \\
\hline Finland & 0.8 & 0.2 & -0.1 & 0.0 & 0.1 & 0.0 & 0.2 & 0.4 & -0.4 & 0.0 & 0.3 & 0.0 & 0.4 & 1.2 \\
\hline France & 1.1 & 0.2 & -0.1 & 0.0 & 0.0 & 0.1 & 0.2 & 0.4 & -0.4 & 0.0 & 0.3 & 0.1 & 0.4 & 1.5 \\
\hline Germany & 0.9 & 0.2 & -0.1 & 0.0 & 0.0 & 0.1 & 0.3 & 0.5 & -0.4 & 0.0 & 0.3 & 0.1 & 0.5 & 1.4 \\
\hline Greece & 0.5 & 0.2 & -0.1 & 0.0 & 0.0 & 0.3 & 0.4 & 0.5 & -0.4 & 0.0 & 0.3 & 0.4 & 0.7 & 1.3 \\
\hline Hungary & 0.3 & 0.2 & -0.1 & 0.0 & 0.1 & 0.2 & 0.3 & 0.6 & -0.4 & 0.0 & 0.5 & 0.2 & 0.8 & 1.0 \\
\hline Iceland & 1.7 & 0.2 & -0.1 & 0.0 & 0.0 & -0.1 & 0.1 & 0.4 & -0.3 & 0.0 & 0.3 & 0.0 & 0.3 & 2.1 \\
\hline $\begin{array}{l}\text { Ireland } \\
\text { slreel }\end{array}$ & 0.5 & 0.2 & -0.1 & 0.0 & 0.0 & 0.1 & 0.2 & 0.5 & -0.4 & 0.0 & 0.2 & 0.1 & 0.4 & 1.0 \\
\hline $\begin{array}{l}\text { Strael } \\
\text { Italy }\end{array}$ & $\begin{array}{l}0.4 \\
0.7\end{array}$ & $\begin{array}{l}0.2 \\
0.2\end{array}$ & $\begin{array}{l}-0.1 \\
-0.1\end{array}$ & $\begin{array}{l}0.0 \\
0.0\end{array}$ & $\begin{array}{l}0.0 \\
0.0\end{array}$ & $\begin{array}{l}0.2 \\
0.2\end{array}$ & $\begin{array}{l}0.3 \\
0.3\end{array}$ & $\begin{array}{l}0.4 \\
0.4\end{array}$ & $\begin{array}{l}-0.3 \\
-0.4\end{array}$ & $\begin{array}{l}0.0 \\
0.0\end{array}$ & 0.2 & 0.3 & 0.5 & 0.9 \\
\hline $\begin{array}{l}\text { tilay } \\
\text { Japan }\end{array}$ & $\begin{array}{l}0.7 \\
0.7\end{array}$ & $\begin{array}{l}0.2 \\
0.3\end{array}$ & $\begin{array}{l}-0.1 \\
-0.1\end{array}$ & $\begin{array}{l}0.0 \\
0.0\end{array}$ & $\begin{array}{l}0.0 \\
0.0\end{array}$ & $\begin{array}{l}0.2 \\
0.1\end{array}$ & $\begin{array}{l}0.3 \\
0.3\end{array}$ & $\begin{array}{l}0.4 \\
0.5\end{array}$ & $\begin{array}{l}-0.4 \\
-0.4\end{array}$ & $\begin{array}{l}0.0 \\
0.0\end{array}$ & $\begin{array}{l}0.3 \\
0.4\end{array}$ & $\begin{array}{l}0.3 \\
0.1\end{array}$ & $\begin{array}{l}0.6 \\
0.6\end{array}$ & $\begin{array}{l}7.3 \\
1.2\end{array}$ \\
\hline Korea & 0.3 & 0.4 & -0.1 & 0.0 & 0.1 & 0.0 & 0.4 & 1.1 & -0.6 & 0.0 & 0.4 & 0.1 & 1.0 & 1.3 \\
\hline Luxembourg & 0.9 & 0.2 & -0.1 & 0.0 & 0.0 & 0.3 & 0.3 & 0.5 & -0.4 & 0.0 & 0.1 & 0.3 & 0.5 & 1.5 \\
\hline Mexico & 0.0 & 0.2 & -0.1 & 0.0 & 0.0 & 0.3 & 0.4 & 0.9 & -0.5 & 0.0 & 0.4 & 0.4 & 1.2 & 1.2 \\
\hline Norway & 2.1 & 0.1 & -0.1 & 0.0 & 0.1 & 0.0 & 0.1 & 0.4 & -0.4 & 0.0 & 0.3 & 0.0 & 0.4 & 2.5 \\
\hline Poland & 0.4 & 0.3 & -0.1 & 0.0 & 0.1 & 0.0 & 0.2 & 0.8 & -0.5 & 0.0 & 0.5 & 0.0 & 0.8 & 1.1 \\
\hline $\begin{array}{l}\text { Portugal } \\
\text { SLovk Renublic }\end{array}$ & 0.1 & 0.2 & -0.1 & 0.0 & 0.0 & 0.1 & 0.2 & 0.5 & -0.4 & 0.0 & 0.3 & 0.1 & 0.6 & 0.7 \\
\hline $\begin{array}{l}\text { Slovak Republic } \\
\text { Slovenia }\end{array}$ & 0.0 & 0.3 & $\begin{array}{l}-0.1 \\
-0.1\end{array}$ & 0.0 & 0.1 & 0.1 & 0.3 & 0.8 & $\begin{array}{l}-0.5 \\
-0.4\end{array}$ & 0.0 & 0.5 & 0.1 & 0.8 & 0.9 \\
\hline $\begin{array}{l}\text { SSlovenia } \\
\text { Spain }\end{array}$ & $\begin{array}{l}0.7 \\
0.5\end{array}$ & $\begin{array}{l}0.2 \\
0.2\end{array}$ & $\begin{array}{l}-0.1 \\
-0.1\end{array}$ & $\begin{array}{l}0.0 \\
0.0\end{array}$ & $\begin{array}{l}0.1 \\
0.0\end{array}$ & $\begin{array}{l}0.1 \\
0.3\end{array}$ & $\begin{array}{l}0.3 \\
0.4\end{array}$ & 0.6 & -0.4 & $\begin{array}{l}0.0 \\
0.0\end{array}$ & 0.4 & $\begin{array}{l}0.1 \\
0.4\end{array}$ & 0.7 & 1.3 \\
\hline $\begin{array}{l}\text { Spain } \\
\text { Sweden }\end{array}$ & $\begin{array}{l}0.5 \\
0.7\end{array}$ & $\begin{array}{l}0.2 \\
0.1\end{array}$ & $\begin{array}{l}-0.1 \\
-0.1\end{array}$ & $\begin{array}{l}0.0 \\
0.0\end{array}$ & $\begin{array}{l}0.0 \\
0.1\end{array}$ & $\begin{array}{l}0.3 \\
0.0\end{array}$ & $\begin{array}{l}0.4 \\
0.1\end{array}$ & $\begin{array}{l}0.6 \\
0.3\end{array}$ & $\begin{array}{l}-0.4 \\
-0.3\end{array}$ & $\begin{array}{l}0.0 \\
0.0\end{array}$ & $\begin{array}{l}0.3 \\
0.3\end{array}$ & $\begin{array}{l}0.4 \\
0.0\end{array}$ & $\begin{array}{l}0.8 \\
0.3\end{array}$ & $\begin{array}{l}7.4 \\
1.0\end{array}$ \\
\hline Switzerland & 1.2 & 0.2 & -0.1 & 0.0 & 0.0 & 0.1 & 0.2 & 0.5 & -0.4 & 0.0 & 0.4 & 0.1 & 0.5 & 1.7 \\
\hline Turkey & 0.0 & 0.2 & -0.1 & 0.0 & 0.1 & 0.1 & 0.3 & 0.9 & -0.5 & 0.0 & 0.4 & 0.6 & 1.3 & 1.4 \\
\hline United Kingdom & 0.9 & 0.1 & -0.1 & 0.0 & 0.0 & 0.1 & 0.1 & 0.3 & -0.3 & 0.0 & 0.3 & 0.1 & 0.4 & 1.2 \\
\hline United States & 0.6 & 0.2 & -0.1 & 0.0 & 0.0 & 0.0 & 0.1 & 0.3 & -0.3 & 0.0 & 0.3 & 0.0 & 0.3 & 0.8 \\
\hline$O E C D$ average ${ }^{1}$ & 0.8 & 0.2 & -0.1 & 0.0 & 0.0 & 0.1 & 0.3 & 0.5 & -0.4 & 0.0 & 0.3 & 0.2 & 0.6 & 1.4 \\
\hline Brazil & 0.0 & 0.3 & -0.1 & 0.0 & 0.0 & 0.0 & 0.2 & 1.0 & -0.6 & 0.0 & 0.3 & -0.1 & 0.6 & 0.6 \\
\hline China & 0.1 & 0.3 & -0.1 & 0.0 & 0.1 & 0.0 & 0.2 & 1.0 & -0.6 & 0.0 & 0.5 & -0.1 & 0.8 & 0.9 \\
\hline India & 0.1 & 0.2 & -0.1 & 0.0 & 0.1 & 0.0 & 0.2 & 0.6 & -0.4 & 0.0 & 0.4 & 0.0 & 0.7 & 0.7 \\
\hline Indonesia & 0.1 & 0.2 & -0.1 & 0.0 & 0.1 & 0.0 & 0.2 & 0.9 & -0.5 & 0.0 & 0.4 & -0.1 & 0.7 & 0.8 \\
\hline Russia & 0.2 & 0.2 & -0.1 & 0.0 & 0.1 & -0.1 & 0.1 & 0.4 & -0.4 & 0.0 & 0.3 & -0.1 & 0.3 & 0.5 \\
\hline South Africa & 0.2 & 0.2 & -0.1 & 0.0 & 0.0 & 0.0 & 0.1 & 0.4 & -0.3 & 0.0 & 0.2 & 0.0 & 0.3 & 0.5 \\
\hline Non-OECD average ${ }^{1}$ & 0.1 & 0.2 & -0.1 & 0.0 & 0.1 & 0.0 & 0.2 & 0.7 & -0.5 & 0.0 & 0.3 & -0.1 & 0.6 & 0.7 \\
\hline Total average $^{7}$ & 0.7 & 0.2 & -0.1 & 0.0 & 0.0 & 0.1 & 0.2 & 0.6 & -0.4 & 0.0 & 0.3 & 0.1 & 0.6 & 1.3 \\
\hline
\end{tabular}


Table A5.14. Breakdown of the projections of total long-term care expenditure for each driver

ECO/WKP(2013)40

Sensitivity analysis: life expectancy +2 standard deviations

\begin{tabular}{|c|c|c|c|c|c|c|c|c|c|c|c|c|c|c|}
\hline & $\begin{array}{l}\text { Long-term care } \\
\text { expenditure as } \\
a \% \text { of GDP } \\
\text { (0) }\end{array}$ & $\begin{array}{l}\text { Pure ageing } \\
\text { effect }\end{array}$ & $\begin{array}{l}\text { Adjustment for } \\
\text { healthy ageing } \\
\text { (2) }\end{array}$ & $\begin{array}{l}\text { Income effect } \\
\text { (3) }\end{array}$ & $\begin{array}{l}\text { Cost disease } \\
\text { effect } \\
\text { (4) }\end{array}$ & $\begin{array}{l}\text { Effect of the } \\
\text { participation } \\
\text { rate of people } \\
\text { aged 50-64 } \\
\text { (5) }\end{array}$ & $\begin{array}{c}\text { Total increase } \\
\text { (6)=Sum (1) to (5) }\end{array}$ & $\begin{array}{l}\text { Pure ageing } \\
\text { effect } \\
\text { (7) }\end{array}$ & $\begin{array}{l}\text { Adjustment for } \\
\text { healthy ageing } \\
\text { (8) }\end{array}$ & Income effect & $\begin{array}{c}\begin{array}{c}\text { Cost disease } \\
\text { effect }\end{array} \\
\text { (10) }\end{array}$ & $\begin{array}{c}\text { Effect of the } \\
\text { participation } \\
\text { rate of people } \\
\text { aged 50-64 } \\
\Rightarrow \quad(11)\end{array}$ & Total increase & $\begin{array}{c}\text { Level as a \% of } \\
\text { GDP } \\
(13)=(0)+(12)\end{array}$ \\
\hline & 2006-2010 & \multicolumn{6}{|c|}{ Increase in \% points of GDP 2010-2030 } & \multicolumn{6}{|c|}{ Increase in \% points of GDP 2010-2060 } & 2060 \\
\hline Australia & 0.0 & 0.2 & 0.0 & 0.0 & 0.1 & 0.1 & 0.4 & 0.5 & 0.0 & 0.0 & 0.4 & 0.1 & 1.0 & 1.0 \\
\hline $\begin{array}{l}\text { Austria } \\
\text { Belqum }\end{array}$ & 1.1 & 0.2 & 0.0 & 0.0 & 0.0 & 0.1 & 0.4 & 0.4 & 0.0 & 0.0 & 0.3 & 0.2 & 0.9 & 2.0 \\
\hline & 1.7 & 0.1 & 0.0 & 0.0 & & 0.2 & 0.4 & 0.3 & 0.0 & 0.0 & 0.3 & 0.3 & 0.9 & \\
\hline $\begin{array}{l}\text { Canada } \\
\text { Chile }\end{array}$ & 1.2 & 0.2 & 0.0 & 0.0 & 0.0 & 0.1 & 0.4 & 0.4 & 0.0 & 0.0 & 0.4 & 0.1 & 1.0 & 2.2 \\
\hline Czech Republic & $\begin{array}{l}0.0 \\
0.3\end{array}-3 \mathrm{r}-\mathrm{r}$ & $\begin{array}{l}0.3 \\
0.2\end{array}$ & $\begin{array}{l}0.0 \\
0.0\end{array}$ & $\begin{array}{l}0.0 \\
0.0\end{array}$ & $\begin{array}{l}0.1 \\
0.1\end{array}$ & $\begin{array}{l}0.3 \\
0.1\end{array}$ & $\begin{array}{l}0.7 \\
0.4\end{array}$ & 0.8 & 0.1 & 0.0 & 0.5 & 0.4 & 1.0 & 1.8 \\
\hline Denmark & 2.2 & 0.2 & 0.0 & 0.0 & 0.0 & 0.1 & 0.3 & 0.4 & 0.0 & 0.0 & 0.3 & 0.1 & 0.8 & $\begin{array}{l}1.4 \\
3.0\end{array}$ \\
\hline Estonia & 0.2 & 0.2 & 0.0 & 0.0 & 0.1 & 0.1 & 0.4 & 0.5 & 0.0 & 0.0 & 0.6 & 0.1 & 1.2 & 1.4 \\
\hline Finland & 0.8 & 0.2 & 0.0 & 0.0 & 0.1 & 0.0 & 0.3 & 0.4 & 0.0 & 0.0 & 0.3 & 0.0 & 0.8 & $\begin{array}{l}1.4 \\
1.6\end{array}$ \\
\hline France & 1.1 & 0.2 & 0.0 & 0.0 & 0.0 & 0.1 & 0.3 & 0.4 & 0.0 & 0.0 & 0.3 & 0.1 & 0.8 & 1.9 \\
\hline Germany & 0.9 & 0.2 & 0.0 & 0.0 & 0.0 & 0.1 & 0.4 & 0.5 & 0.0 & 0.0 & 0.3 & 0.1 & 0.9 & 1.9 \\
\hline Greece & & & & & & & 0.5 & 0.5 & & & & & & 1.7 \\
\hline Hungary & 0.3 & 0.2 & 0.0 & 0.0 & 0.1 & 0.2 & 0.4 & 0.6 & 0.0 & 0.0 & 0.5 & 0.2 & 1.2 & 1.5 \\
\hline Iceland & 1.7 & 0.2 & 0.0 & 0.0 & 0.0 & -0.1 & 0.2 & 0.4 & 0.0 & 0.0 & 0.3 & 0.0 & 0.7 & 2.4 \\
\hline $\begin{array}{l}\text { Ireland } \\
\text { |lrael| }\end{array}$ & 0.5 & 0.2 & 0.0 & 0.0 & 0.0 & 0.1 & 0.3 & 0.5 & 0.0 & 0.0 & 0.2 & 0.1 & 0.9 & 1.4 \\
\hline $\begin{array}{l}\text { Itraeal } \\
\text { Italy }\end{array}$ & $\begin{array}{l}0.4 \\
0.7\end{array}$ & $\begin{array}{l}0.2 \\
0.2\end{array}$ & $\begin{array}{l}0.0 \\
0.0\end{array}$ & $\begin{array}{l}0.0 \\
0.0\end{array}$ & $\begin{array}{l}0.0 \\
0.0\end{array}$ & $\begin{array}{l}0.2 \\
0.2\end{array}$ & $\begin{array}{l}0.4 \\
0.4\end{array}$ & $\begin{array}{l}0.4 \\
0.4\end{array}$ & $\begin{array}{l}0.0 \\
0.0\end{array}$ & $\begin{array}{l}0.0 \\
0.0\end{array}$ & $\begin{array}{l}0.2 \\
0.3\end{array}$ & $\begin{array}{l}0.3 \\
0.3\end{array}$ & $\begin{array}{l}0.9 \\
1.0\end{array}$ & $\begin{array}{l}1.3 \\
1.8\end{array}$ \\
\hline $\begin{array}{l}\text { Japan } \\
\text { Japan }\end{array}$ & 0.7 & $\begin{array}{l}0.2 \\
0.3\end{array}$ & $\begin{array}{l}0.0 \\
0.0\end{array}$ & $\begin{array}{l}0.0 \\
0.0\end{array}$ & 0.0 & $\begin{array}{l}0.2 \\
0.1\end{array}$ & $\begin{array}{l}0.4 \\
0.4\end{array}$ & $\begin{array}{l}0.4 \\
0.5\end{array}$ & $\begin{array}{l}0.0 \\
0.0\end{array}$ & 0.0 & 0.4 & 0.1 & 1.0 & $\begin{array}{l}1.8 \\
1.7\end{array}$ \\
\hline Korea & 0.3 & 0.4 & 0.0 & 0.0 & 0.1 & 0.0 & 0.5 & 1.1 & 0.1 & 0.0 & 0.4 & 0.1 & 1.7 & 2.0 \\
\hline Luxembourg & 0.9 & 0.2 & 0.0 & 0.0 & 0.0 & 0.3 & 0.5 & 0.5 & 0.0 & 0.0 & 0.1 & 0.3 & 1.0 & 1.9 \\
\hline Mexico & 0.0 & 0.2 & 0.0 & 0.0 & 0.0 & 0.3 & 0.5 & 0.9 & 0.1 & 0.0 & 0.4 & 0.4 & 1.8 & 1.8 \\
\hline Netherlands & 2.3 & 0.3 & 0.0 & 0.0 & 0.0 & 0.2 & 0.5 & 0.5 & 0.0 & 0.0 & 0.3 & 0.2 & 1.1 & 3.4 \\
\hline New Zealand & 1.3 & 0.2 & 0.0 & 0.0 & 0.0 & 0.1 & 0.3 & 0.5 & 0.0 & 0.0 & 0.4 & 0.1 & 1.0 & 2.3 \\
\hline & 2.1 & 0.1 & 0.0 & 0.0 & 0.1 & 0.0 & 0.2 & 0.4 & 0.0 & 0.0 & 0.3 & 0.0 & 0.8 & 2.9 \\
\hline Poland & 0.4 & 0.3 & 0.0 & 0.0 & 0.1 & 0.0 & 0.4 & 0.8 & 0.1 & 0.0 & 0.5 & 0.0 & 1.3 & 1.7 \\
\hline Portugal & 0.1 & 0.2 & 0.0 & 0.0 & 0.0 & 0.1 & 0.3 & 0.5 & 0.0 & 0.0 & 0.3 & 0.1 & 1.0 & 1.1 \\
\hline Slovak Republic & 0.0 & 0.3 & 0.0 & 0.0 & 0.1 & 0.1 & 0.5 & 0.8 & 0.1 & 0.0 & 0.5 & 0.1 & 1.4 & 1.5 \\
\hline Slovenia & 0.7 & 0.2 & 0.0 & 0.0 & 0.1 & 0.1 & 0.4 & 0.6 & 0.0 & 0.0 & 0.4 & 0.1 & 1.2 & 1.8 \\
\hline $\begin{array}{l}\text { Spain } \\
\text { Sweden }\end{array}$ & $\begin{array}{l}0.5 \\
0.7\end{array}$ & 0.2 & 0.0 & 0.0 & 0.0 & 0.3 & 0.5 & 0.6 & $\begin{array}{l}0.0 \\
0.0\end{array}$ & 0.0 & 0.3 & 0.4 & 1.3 & 1.8 \\
\hline $\begin{array}{l}\text { Sweden } \\
\text { Switerland }\end{array}$ & 12 & & 00 & 0.0 & 0.1 & 0.0 & 0.2 & 0.3 & & 0.0 & & & & \\
\hline $\begin{array}{l}\text { Switzerland } \\
\text { Turkey }\end{array}$ & $\begin{array}{l}1.2 \\
0.0\end{array}$ & $\begin{array}{l}0.2 \\
0.2\end{array}$ & 0.0 & $\begin{array}{l}0.0 \\
0.0\end{array}$ & 0.0 & 0.1 & 0.3 & 0.5 & 0.0 & 0.0 & 0.4 & 0.1 & 1.0 & 2.2 \\
\hline Turkey & 0.0 & 0.2 & 0.0 & 0.0 & 0.1 & 0.1 & 0.4 & 0.9 & 0.1 & 0.0 & 0.4 & 0.6 & 1.9 & 1.9 \\
\hline $\begin{array}{l}\text { Unitited Kingdom } \\
\text { United States }\end{array}$ & $\begin{array}{l}0.9 \\
0.6\end{array}$ & $\begin{array}{l}0.1 \\
0.2\end{array}$ & $\begin{array}{l}0.0 \\
0.0\end{array}$ & $\begin{array}{l}0.0 \\
0.0\end{array}$ & $\begin{array}{l}0.0 \\
0.0\end{array}$ & $\begin{array}{l}0.1 \\
0.0\end{array}$ & $\begin{array}{l}0.3 \\
0.2\end{array}$ & $\begin{array}{l}0.3 \\
0.3\end{array}$ & $\begin{array}{l}0.0 \\
0.0\end{array}$ & $\begin{array}{l}0.0 \\
0.0\end{array}$ & $\begin{array}{l}0.3 \\
0.3\end{array}$ & $\begin{array}{l}0.1 \\
0.0\end{array}$ & $\begin{array}{l}0.7 \\
0.6\end{array}$ & $\begin{array}{l}1.6 \\
1.2\end{array}$ \\
\hline$O E C D$ average ${ }^{1}$ & 0.8 & 0.2 & 0.0 & 0.0 & 0.0 & 0.1 & 0.4 & 0.5 & 0.0 & 0.0 & 0.3 & 0.2 & 1.1 & 1.9 \\
\hline Brazil & 0.0 & 0.3 & 0.0 & 0.0 & 0.0 & 0.0 & 0.3 & 1.0 & 0.1 & 0.0 & 0.3 & -0.1 & 1.2 & 1.2 \\
\hline & 0.1 & 0.3 & 0.0 & 0.0 & 0.1 & 0.0 & 0.4 & 1.0 & 0.1 & 0.0 & 0.5 & & 1.5 & 1.6 \\
\hline India & 0.1 & 0.2 & 0.0 & 0.0 & 0.1 & 0.0 & 0.3 & 0.6 & 0.0 & 0.0 & 0.4 & 0.0 & 1.1 & 1.1 \\
\hline $\begin{array}{l}\text { IIdonesia } \\
\text { Russia }\end{array}$ & $\begin{array}{l}0.1 \\
0.2\end{array}$ & $\begin{array}{l}0.2 \\
0.2\end{array}$ & $\begin{array}{l}0.0 \\
0.0\end{array}$ & $\begin{array}{l}0.0 \\
0.0\end{array}$ & $\begin{array}{l}0.1 \\
0.1\end{array}$ & $\begin{array}{c}0.0 \\
-0.1\end{array}$ & $\begin{array}{l}0.3 \\
0.2\end{array}$ & 0.9 & $\begin{array}{l}0.1 \\
0.0\end{array}$ & $\begin{array}{l}0.0 \\
0 \\
0\end{array}$ & $\begin{array}{l}0.4 \\
0.3\end{array}$ & $\begin{array}{l}-0.1 \\
-0.1\end{array}$ & $\begin{array}{l}1.3 \\
0.7\end{array}$ & $\begin{array}{l}1.4 \\
0.9\end{array}$ \\
\hline South Africa & 0.2 & $\begin{array}{l}0.2 \\
0.2\end{array}$ & $\begin{array}{l}0.0 \\
0.0\end{array}$ & 0.0 & $\begin{array}{l}0.1 \\
0.0\end{array}$ & $\begin{array}{l}-0.1 \\
0.0\end{array}$ & $\begin{array}{l}0.2 \\
0.2\end{array}$ & $\begin{array}{l}0.4 \\
0.4\end{array}$ & $\begin{array}{l}0.0 \\
0.0\end{array}$ & $\begin{array}{l}0.0 \\
0.0\end{array}$ & $\begin{array}{l}0.3 \\
0.2\end{array}$ & 0.0 & 0.6 & $\begin{array}{l}0.9 \\
0.8\end{array}$ \\
\hline Non-OECD average 1 & 0.1 & 0.2 & 0.0 & 0.0 & 0.1 & 0.0 & 0.3 & 0.7 & 0.0 & 0.0 & 0.3 & -0.1 & 1.1 & 1.2 \\
\hline Total average ${ }^{1}$ & 0.7 & 0.2 & 0.0 & 0.0 & 0.0 & 0.1 & 0.4 & 0.6 & 0.0 & 0.0 & 0.3 & 0.1 & 1.1 & 1.8 \\
\hline
\end{tabular}


Table A5.15. Breakdown of the projections of total long-term care expenditure for each driver

Sensitivity analysis: health expenditure cost-pressure scenario

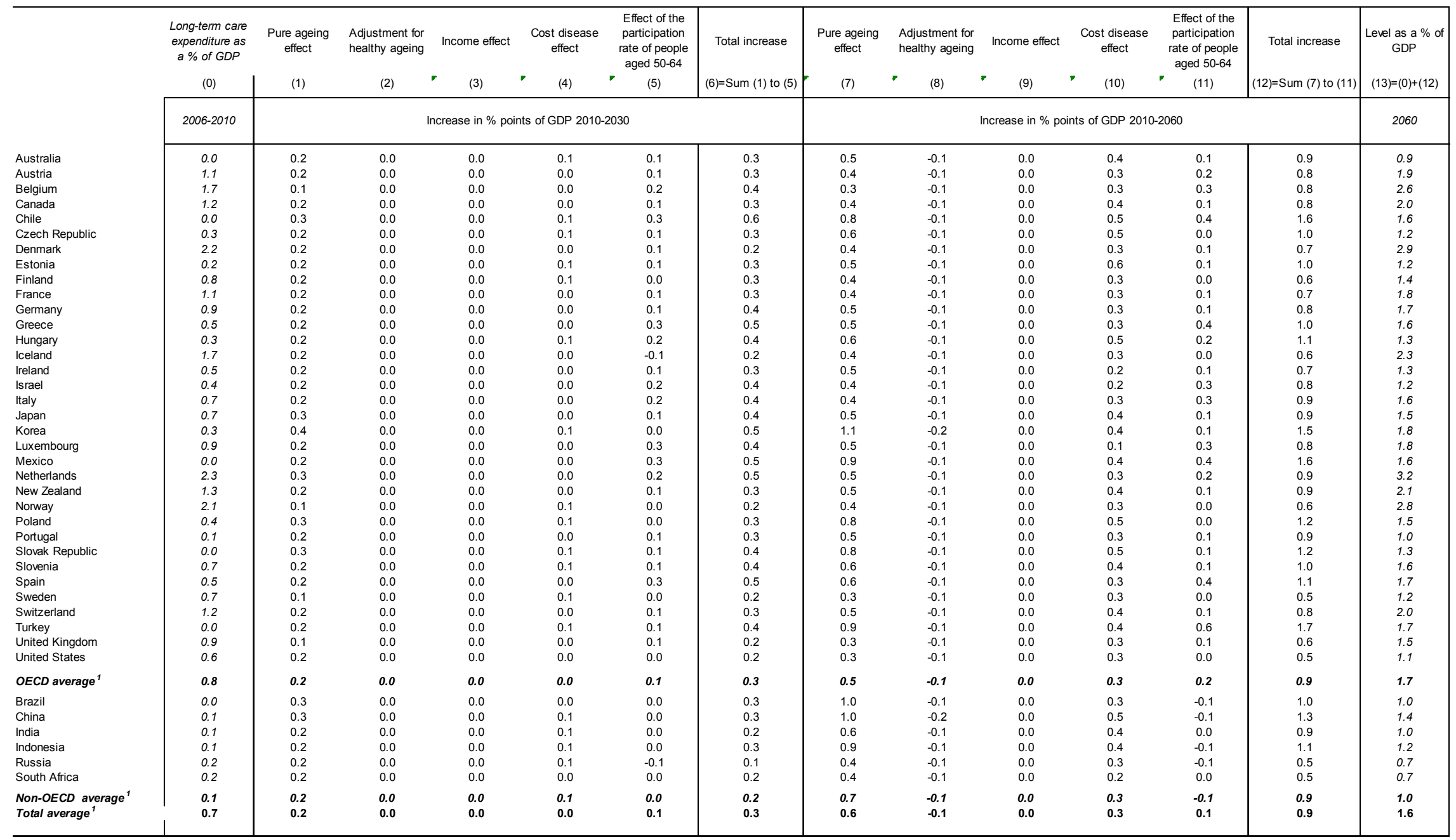


ECO/WKP(2013)40

\section{REFERENCES}

Acemoglu, D., A. Finkelstein and M. Notowidigdo (2009), "Income and Health Spending: Evidence from Oil Shocks", CEPR Discussion Papers No. 7255.

Alzheimer Europe (2006), Dementia in Europe Yearbook 2006, Luxembourg

Aprile, R. (2004), "How to Take Account of Death-Related Costs in Projecting Health Care Expenditure Updated Version”, Ragioneria Generale Dello Stato.

Atella V. and G. Marini (2004), "The Determinants of Health Care Expenditure: A Never Ending Story?", SSRN Working Paper No 607162.

Baltagi B.H. and F. Moscone (2010), "Health Care Expenditure and Income in the OECD Reconsidered: Evidence from Panel Data", Institute for the Study of Labor (IZA).

Baumol, W.J. (1967), "Macroeconomics of Unbalanced Growth: The Anatomy of Urban Crisis", American Economic Review 57: pp. 415-426.

Baumol, W.J. (1993), "Health Care, Education and the Cost of Disease: A Looming Crisis for Public Choice", Public Choice 77:17-28.

Bech, M. et al. (2011), "Ageing and Health Care Expenditure in EU-15", European Journal of Health Economics 12, pp. 469-478.

Bessen J. and T. Grid (2012), “Which Patent Systems Are Better For Inventors?”, forthcoming.

Blomqvist, A.G. and R.A.L. Carter (1997), "Is Health Care Really a Luxury?", Journal of Health Economics 16 2, pp. 207-230.

Breyer F. and S. Felder (2006), "Life Expectancy and Health Care Expenditures: A New Calculation for Germany Using the Costs of Dying", Health Policy 75, pp. 178-186.

Breyer F, J. Costa-i-Font and S. Felder (2011), “Does Ageing Really Affect Health Expenditures? If so, Why?", Vox EU, May.

Burniaux, J.-M., R. Duval and F. Jaumotte (2003), "Coping with Ageing: a Dynamic Approach to Quantify the Impact of Alternative Policy Options on Future Labour Supply in OECD Countries", OECD Economics Department Working Papers No. 371, OECD, Paris.

Colombo, F. et al (2011), "Help Wanted? Providing and Paying for Long-Term Care", OECD Health Policy Studies, OECD Publishing, Paris.

Comas-Herrera, A. and R. Wittenberg, eds., (2003), European study of Long-Term Care Expenditure: Investigating the Sensitivity of Projections of Future Long-Term Care Expenditure in Germany, 
Spain, Italy and the United Kingdom to Changes in Assumptions About Demography, Dependency, Informal Care, Formal Care and Unit Costs, PSSRU, LSE Health and Social Care, London School of Economics.

Costa-Font, J., M. Gemmill and G. Rubert (2011), "Biases in the Healthcare Luxury Good Hypothesis?: A Meta-Regression Analysis”, Journal of the Royal Statistical Society, Series A 174, Part 1, pp. 95-107.

Culyer, A.J. (1990), “Cost Containment in Europe”, Health Care Systems in Transition, OECD, Paris.

Cutler, D. (2001), "The Reduction in Disability among the Elderly", Proceedings of the National Academy of Science, Vol. 98, No. 12, June.

Di Matteo, L. and R. Di Matteo (1998), "Evidence on the Determinants of Canadian Provincial Government Health Expenditures: 1965-1991”, Journal of Health Economics 17(2), pp. 211-228

Dormont, B. and H. Huber (2005), "Ageing and Changes in Medical Practices: Reassessing the Influence of Demography", mimeo, THEMA University of Paris X, Paris.

Dormont, B., M. Grignon and H. Huber (2006), "Health Expenditure Growth: Reassessing the Threat of Ageing", Health Economics, 15 (9), pp. 947-63.

Dormont, B. et al. (2011), "Health Expenditures, Longevity and Growth", in Ageing, Health and Productivity, Oxford University Press.

Dreger, C. and H.-E. Reimers (2005), "Health Care Expenditures in OECD Countries: A panel Unit Root and Cointegration Analysis", IZA Discussion Paper 1469, Bonn.

Duarte, F. (2012), "Price Elasticity of Expenditure Across Health Care Service", Journal of Health Economics 31, pp. 824-841.

Duval, R. and C. de la Maisonneuve (2010), "Long-Run Growth Scenarios for the World Economy", Journal of Policy Modeling, Elsevier, Vol. 32(1).

European Commission (2009), Ageing Report: Economic and Budgetary Projections for the EU-27 Member States, 2008-2060.

Felder, S., M. Meier and H. Schmitt (2000), "Health Care Expenditure in the Last Months of Life", Journal of Health Economics, 19, pp. 679-95.

Fouré, J., A. Bénassy-Quéré and L. Fontagné (2010), "The World Economy in 2050: A Tentative Picture", CEPII, Working Paper No. 2010-27.

Freeman, D.G. (2003), "Is Health Care a Necessity or a Luxury? Pooled Estimates of Income Elasticity from US State-Level Data", Applied Economics, 35(5): pp. 495-502.

Fuchs, V. (1972), Essays in the Economics of Health and Medical Care, National Bureau of Economic Research, New York.

Fuchs, V. (1984), “ “Though Much is Taken” -- Reflections on Ageing, Health and Medical Care”, NBER Working Paper No.1269. 
Fujisawa, R. and F. Colombo (2009), "The Long-term Care Workforce: Overview and Strategies to Adapt Supply to a Growing Demand”, OECD Health Working Paper, No. 44, OECD Publishing, Paris.

Gerdtham, U., J. Sogaard., F. Anderson and B. Jonsson (1992), “An Econometric Analysis of Health Care Expenditure: A Cross-Section Study of the OECD Countries", Journal of Health Economics, Vol. 11, No. 1, pp. 63-84.

Getzen, T. (2000), "Health Care is an Individual Necessity and a National Luxury: Applying Multilevel Decision Models to the Analysis of Health Care Expenditure", Journal of Health Economics 19, pp. 259-270.

Goldman et al. (2005), "Consequences of Health Trends and Medical Innovation for the Future Elderly", Health Affairs, September.

Gray, A. (2004), Estimating the impact of ageing populations on future health expenditures, Public lecture to the National Institute of Economics and Business and the National Institute of Health and Human Science, 4 November, Canberra.

Hall, R. and C. Jones (2007), "The Value of Life and the Rise in Health Spending”, The Quarterly Journal of Economics, February, pp. 39-72.

Holly, A., X. Ke and P. Saksena (2011), "The Determinants of Health Expenditure: A Country-Level Panel Data Analysis", World Health Organisation Working Paper.

Hitiris, T. and J. Posnett (1992), "The Determinants and Effects of Health Expenditure in Developed Countries", Journal of Health Economics, Vol. 11, No. 2, pp. 173-81.

Jacobzone, S. (2003), "Ageing and the Challenges of New Technologies: Can OECD Social and Health Care Systems Provide for the Future?", The Geneva Papers on Risk and Insurance, Vol. 28, No. 2, April, pp. 254-74.

Johansson et al. (2012), "Long-Term Growth Scenarios", OECD Economics Department Working Papers No 1000, OECD, Paris.

Jönsson, B. and I. Eckerlund (2003), "Why do Different Countries Spend Different Amounts on Health Care?", A Disease-based Comparison of Health Systems, OECD, Paris.

KPMG Consulting (2001), Impact of New Technology on Victorian Public Hospital Costs, Report to the Victorian Department of Human Services, September.

Moise, P. and S. Jacobzone (2003), "Population Ageing, Health Expenditure and Treatment: an ARD Perspective", A Disease-based Comparison of Health Systems, OECD, Paris.

Moscone F. And Tosetti E. (2010), "Health expenditure and income in the United States", Health Economics 19: 1385-1403.

Mushkin, E.P. and J.S. Landefeld (1979), Biomedical Research: Costs and Benefits, Ballinger Publishing Company, Cambridge, Massachusetts.

Narayan P.K., S. Narayan and R. Smyth (2011), "Is Health Care Really a Luxury in OECD Countries? Evidence from Alternative Price Deflators", Applied Economics 43, pp. 3631-3643. 
Newhouse, J.P. (1977), "Medical Care Expenditure: A Cross-National Survey", Journal of Human Resources 12, pp. pp. 115-125.

Newhouse (1992), "Medical Care Costs: How Much Welfare Loss?", Journal of Economic Perspectives, Vol. 6, No. 3, pp. 3-21.

OECD (2005), Long-term Care for Older People, Paris.

OECD (2006), "Projecting OECD Health and Long-Term Care Expenditures: What are the Main Drivers?", OECD Economics Department Working Papers No. 477, OECD, Paris.

OECD (2010), Health Care Systems: Efficiency and Policy Settings, OECD Publishing, Paris.

OECD (2012), OECD Economic Outlook, Vol. 2012/1, OECD Publishing.

Okunade, A.A., and V.N.R. Murthy (2002), "Technology as a Major Driver of Health Costs: A Cointegration Analysis of the Newhouse Conjecture", Journal of Health Economics 21, pp. 147-159.

Oliveira Martins, J. and C. de la Maisonneuve (2006), "The Drivers of Public Expenditure on Health and Long-Term Care: An Integrated Approach”, OECD Economic Studies No. 43, 2006/2, OECD, Paris.

Productivity Commission (2005a), Economic Implications of an Ageing Australia, Research Report, Canberra.

Productivity Commission (2005b), Impacts of Medical Technology in Australia, Progress Report, Melbourne, April.

Richardson, J. and I. Robertson (1999), "Ageing and the Cost of Health Services", in Policy Implications of the Ageing of Australia's Population, Productivity Commission and Melbourne Institute, Canberra.

Seshamani, M. and A. Gray (2004), "A Longitudinal Study of the Effects of Age and Time to Death on Hospital Costs", Journal of Health Economics, 23, pp. 217-35.

Sheehan, P. (2002), "Health Costs, Innovation and Ageing", Pharmaceutical Industry Working Paper Series No. 9, Centre for Strategic Economic Studies, Victoria University of Technology, Melbourne.

Viitanen, T.K. (2005), "Informal Elderly Care and Female Labour Force Participation Across Europe", Center for European Policy Studies, ENEPRI Research Reports No. 13, 1, July.

Wanless, D. (2001), Securing our Future Health: Taking a Long-Term View, Interim Report, HM Treasury, London.

Werblow, A., S. Felder and P. Zweifel (2007), "Population Ageing and Health Care Expenditure: A School of 'Red Herrings'?", Health Economics, 16: pp. 1109-26.

Yang, Z., E.C. Norton and S.C. Stearns (2003), "Longevity and Health Care Expenditures: The Real Reasons Older People Spend More”, Journal of Gerontology, Vol. 58B, No. 1, S2-S10.

Zweifel P., S. Felder, and M. Meiers (1999), "Ageing Of Population And Health Care Expenditure: A Red Herring?", Health Economics, 8: pp. 485-496. 


\section{WORKING PAPERS}

The full series of Economics Department Working Papers can be consulted at www.oecd.org/eco/workingpapers/

1047. $R \& D$, patenting and growth: the role of public policy

(May 2013) by Ben Westmore

1046. Knowledge-based capital, innovation and resource allocation (May 2013) by Dan Andrews and Chiara Criscuolo

1045. Reforms for a Cleaner, Healthier Environment in China (April 2013) by Sam Hill

1044. Making the tax system less distortive in Switzerland (April 2013) by Andrés Fuentes

1043. The determinants of informality in Mexico's states (April 2013) by Sean M. Dougherty and Octavio Escobar

1042. Legal reform, contract enforcement and firm size in Mexico (April 2013) by Sean M. Dougherty

1041. Improving the economic situation of young people in France (April 2013) by Hervé Boulhol Améliorer la situation économique des jeunes en France (avril 2013) par Hervé Boulhol

1040. Improving employment prospects for young workers in Spain (April 2013) by Anita Wölfl

1039. Youth labour market performance in Spain and its determinants - a micro-level perspective (April 2013) by Juan J. Dolado, Marcel Jansen, Florentino Felgueroso, Andres Fuentes and Anita Wölfl

1038. The efficiency and equity of the tax and transfer system in France (April 2013) by Balázs Égert

Efficacité et équité du système de prélèvements et de transferts en France (avril 2013) par Balázs Égert

1037. Income inequality and poverty in Colombia. Part 2. The redistributive impact of taxes and transfers (April 2013) by Isabelle Joumard and Juliana Londoño Vélez

1036. Income inequality and poverty in Colombia. Part 1. The role of the labour market (April 2013) by Isabelle Joumard and Juliana Londoño Vélez

1035. Policy options to durably resolve euro area imbalances (March 2013) by Yvan Guillemette and Dave Turner 
1034. Labour market, welfare reform and inequality in the United Kingdom (March 2013) by Christophe André, Clara Garcia, Giulia Giupponi and Jon Kristian Pareliussen

1033. Work incentives and Universal Credit - reform of the benefit system in the United Kingdom (March 2013) by Jon Kristian Pareliussen

1032. Strengthening social cohesion in Luxembourg: making efficiency and equity go hand in hand (March 2013) by Jean-Marc Fournier and Clara Garcia

1031. The price of oil - Will it start rising again?

(March 2013) by Jean-Marc Fournier, Isabell Koske, Isabelle Wanner and Vera Zipperer

1030. The system of revenue sharing and fiscal transfers in China (February 2013) by Xiao Wang and Richard Herd

1029. The declining competitiveness of French firms reflects a generalised supply-side problem (February 2013) by Hervé Boulhol and Patrizio Sicari

1028. Do the overall level and dispersion of socio-economic background measures explain France's gap in PISA scores?

(February 2013 by Hervé Boulhol and Patrizio Sicari

1027. Labour market performance by age groups: a focus on France

(February 2013) by Hervé Boulhol and Patrizio Sicari

1026. Moving towards a single labour contract: pros, cons and mixed feelings

(February 2013) by Nicolas Lepage-Saucier, Juliette Schleich and Etienne Wasmer

1025. Boosting productivity in Australia

(January 2013) by Vassiliki Koutsogeorgopoulou and Omar Barbiero

1024. Housing, financial and capital taxation policies to ensure robust growth in Sweden (January 2013) by Müge Adalet McGowan

1023. Labour market and social policies to foster more inclusive growth in Sweden (January 2013) by Stéphanie Jamet, Thomas Chalaux and Vincent Koen

1022. Educational attainment and labour market outcomes in South Africa, 1994-2010 (January 2013) by Nicola Branson and Murray Leibbrandt

1021. Education quality and labour market outcomes in South Africa

(January 2013) by Nicola Branson and Murray Leibbrandt

1020. Do policies that reduce unemployment raise its volatility? Evidence from OECD countries (January 2013) by Alain de Serres and Fabrice Murtin

1019. Slovakia: A catching up euro area member in and out of the crisis (January 2013) by Jarko Fidrmuc, Caroline Klein, Robert Price and Andreas Wörgötter 